\title{
Site U1317
}

\author{
Expedition 307 Scientists $^{2}$
}

\section{Chapter contents}

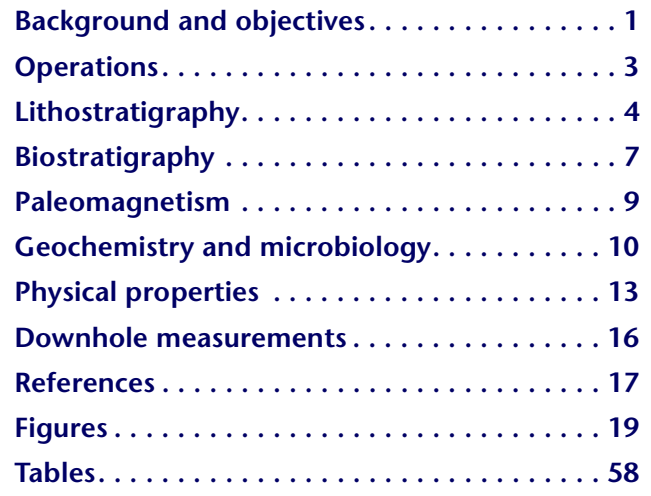

${ }^{1}$ Expedition 307 Scientists, 2006. Site U1317. In Ferdelman, T.G., Kano, A., Williams, T., Henriet, J.-P., and the Expedition 307 Scientists. Proc. IODP, 307: Washington, DC (Integrated Ocean Drilling Program Management International, Inc.). doi:10.2204/ iodp.proc.307.104.2006

2Expedition 307 Scientists' addresses.

\section{Background and objectives}

Site U1317 is located on the northwest shoulder of Challenger Mound $\left(51^{\circ} 22.8^{\prime} \mathrm{N}, 11^{\circ} 43.1^{\prime} \mathrm{W} ; 781-815 \mathrm{~m}\right.$ water depth). Challenger Mound is a part of the Belgica mound province, where outcropping and buried mounds occur in water depths of 600-900 m on the eastern slope of Porcupine Seabight on the southwest continental margin of Ireland (Fig. F1). The mound has an elongated shape oriented along a north-northeast to south-southwest axis and is partially buried under Pleistocene drift sediments. More sediment trapping occurs on the eastern upslope side, leaving only $30 \mathrm{~m}$ of Challenger Mound exposed. On the downslope side (location of Site U1316), less sediment trapping and erosive northward-flowing currents leave $70-80 \mathrm{~m}$ of the mound exposed (Van Rooij et al., 2003). An oval plateau demarcates the summit; however, the slopes of the mound grade steeply at an angle of $20^{\circ}-33^{\circ}$. Present-day water masses in Porcupine Seabight flow generally northward and include European North Atlantic Water (ENAW) down to $\sim 750 \mathrm{~m}$. The ENAW overlies a core of Mediterranean Outflow Water (MOW) that reaches to $\sim 1500 \mathrm{~m}$ and is marked by a salinity maximum and oxygen minimum. North East Atlantic Deep Water lies below 1500 m (Rice et al., 1991; White, 2001). De Mol et al. (2002) hypothesize that MOW plays an important role in the distribution of azooxanthellate cold-water corals found living on the flanks of Porcupine Seabight.

The mounds of Porcupine Seabight, including the mounds of the Belgica mound province, are renowned for their coral cover. On some mounds, living deep-sea corals Lophelia pertusa and $\mathrm{Ma}$ drepora oculata often form dense thickets (De Mol et al., 2002). Challenger Mound, however, has little to no live coral coverage. Surface sediments near the top of the mound consist principally of sediment-clogged dead coral framework, coral rubble, and other skeletal remains of various organisms (Foubert et al., 2005). Shallow piston coring (Marion Dufresne Core MD01-2451G) recovered on-mound sediments of the uppermost 12.8 meters below seafloor (mbsf) that mostly consist of coral floatstone. The supporting carbonate matrix principally consists of calcareous nannofossils interspersed with occasional layers of siliciclastic material $\sim 1 \mathrm{~m}$ thick (Foubert et al., 2005).

Two of the previously described seismic units, P1 (mound substratum) and P3 (mound and enclosing sediments), are encountered at this site (see "Physical properties" in the "Site U1316" chap- 
ter). Challenger Mound roots on the regional erosional unconformity separating seismic Units P1 and P3 (Fig. F2; see Fig. F3 in the "Expedition 307 summary" chapter). The mound appears on seismic profiles as an almost acoustically transparent domeshaped structure. The mound is bounded by diffraction hyperbolae originating at the summit of the mound. Inside the mound, no internal reflectors have been recognized, indicating a uniform facies without any large acoustic impedance differences. The mound acoustic facies might also be interpreted as a loss of seismic energy due to scattering or absorption by the rough seabed and internal structure of the mound. However, an important observation is that the reflectors underneath the mounds show reduced amplitudes, although the reflectors do not completely disappear. Thus, not all the seismic energy is absorbed or dispersed inside the mound facies (De Mol et al., 2005). Analysis of velocity pull-ups of single-channel seismic indicates that the seismic facies of the coral banks is homogeneous and transparent with an estimated internal velocity of $1850 \pm 50$ $\mathrm{m} / \mathrm{s}$ (De Mol et al., 2002). This velocity suggests a carbonate-rich sediment (velocity $=2300 \mathrm{~m} / \mathrm{s}$ ) intermixed with terrigeneous material (velocity $=1700$ $\mathrm{m} / \mathrm{s}$ ), as groundtruthed by the surficial sediment samples (Foubert et al., 2005).

The substratum of the mound is characterized by a set of clinoforms formed by a number of superposed sigmoid reflectors of seismic Unit P1 (Fig. F2). These clinoforms are frequently characterized by a highamplitude top sigmoid reflector. This seismic facies is interpreted as migrating drift bodies (Van Rooij et al., 2003; De Mol et al., 2005). The high amplitude and the reversals of signal polarity of these top sigmoidreflectors indicate that these clinoforms could have contained traces of gas (Henriet et al., 2002) or a remarkable change in lithology (De Mol et al., 2005).

A two-dimensional basin model predicts a potential focusing of gas migration toward the Belgica mounds where the Cretaceous-Tertiary permeable layers pinch out beneath the mound area (see Fig. F4 in the "Expedition 307 summary" chapter) (Naeth et al., 2005). Modeling results based on seismic lines of industrial origin and six exploration wells indicate that Jurassic and older source rocks are mature to overmature throughout the basin. The reconstruction shows that seeping gas may have been available for methanotrophic bacteria and related formation of hardgrounds since the Miocene.

Based on the seismic profiling, Henriet et al. (2002) suggested a developmental model of Challenger Mound that consists of four stages. The initial stage may relate to fluid venting and authigenic carbonate precipitation, which provided a hardground for cor- als to colonize. The second stage involves the catalyzation of the mound growth by the settling of corals on the hardground in connection with microbiologically induced carbonate precipitation. Then, further growth of corals developed a carbonate mound in the third stage. Pelagic ooze and currenttransported siliciclastic sediments were trapped in the framework of branching corals. In the final stage, Challenger Mound was buried asymmetrically with drift sediments.

An alternative hypothesis for the initiation and mound development invokes oceanographic control. Strong bottom currents in the Belgica mound province that result from internal tidal wave effects at the boundary between MOW and ENAW provides suspended food for filter-feeding cold-water corals, sweeps the polyps clean of detritus, and prevents burial of the corals by sediment. Initiation and development of coral growth can be related to major oceanographic changes in the Pliocene subsequent to the closure of the Isthmus of Panama (De Mol et al., 2002, 2005; Von Rooij et al., 2003).

Scientific drilling of Challenger Mound was the central objective of Expedition 307. Specific objectives of drilling Site U1317 were as follows:

1. Establish what kind of surface the mound was built on; for instance, whether the mound base is on a carbonate hardground of microbial origin and whether past geofluid migration events acted as a prime trigger for mound genesis.

2. Describe stratigraphy, lithology, and diagenetic characteristics for establishing the principal depositional model of cold-water coral banks including timing of key mound-building phases. This will help answer the question of whether Challenger Mound provides a present-day analog for understanding the Phanerozoic reef mounds.

3. Define the relationship, if any, between the mound-developing event and global oceanographic events that might have formed erosional surfaces displayed on high-resolution seismic profiles. Cores penetrating these unconformities have to be analyzed by means of high-resolution stratigraphy. The well-established biostratigraphy for the Neogene marine sections of the North Atlantic will support interpretations of unconformities. A series of well-established proxies will be used to reconstruct high-resolution paleoclimate changes. In addition, the mound can be a high-resolution paleoclimate recorder because of its high depositional rate and contents of organic skeletons.

4. Analyze geochemical and microbiological profiles that define the sequence of microbial communities and geomicrobial reaction throughout the drilled sections. This will also prepare the basic in- 
formation to understand the diagenetic processes within the mounds. As putative biological constructions associated with geofluids, mounds may provide unique insight into the deep biosphere.

\section{Operations}

The vessel was moved $0.5 \mathrm{nmi}$ in dynamic positioning (DP) mode with the drill string in the water from Site U1316 to Site U1317. A positioning beacon was deployed at $1837 \mathrm{~h}$ on 2 May 2005. The vessel moved in DP mode to position over the site coordinates.

\section{Hole U1317A}

There was some difficulty obtaining an accurate reading from the PDR because of the steep bathymetric slopes of the carbonate mound. The PDR tended to give readings shallower, by as much as $40 \mathrm{~m}$, than the actual water depth at the position of the rig floor. Because of the tight restrictions concerning the allowed locations for drilling the mound, this mismatch caused several hours delay while we established our exact location. After the drill string was spaced out, Hole U1317A was spudded with the advanced piston corer (APC) at $2335 \mathrm{~h}$ on 2 May 2005, and a seafloor depth of 832.5 mbrf was established.

Sixteen APC cores advanced to 130.8 mbsf (956.8 mbrf) (recovery $=105 \%)$. Perfluorocarbon tracer (PFT) and microsphere tracers were run on all cores. APC temperature tool measurements were taken at $25.5,63.5$, and $110.0 \mathrm{mbsf}$, and the Tensor orientation tool took measurements from 25.5 to 63.5 mbsf. Overpulls were required on all temperature runs (70 $\mathrm{klb}$ at $110.0 \mathrm{mbsf})$. The coring assembly was switched to extended core barrel (XCB), and two $\mathrm{XCB}$ cores advanced an additional $8.0 \mathrm{~m}$ to a total depth (TD) in Hole U1317A of 138.8 mbsf (964.8 mbrf; recovery $=63 \%$ ). The drill string was pulled clear of the seafloor at $1815 \mathrm{~h}$ on 3 May, officially ending operations in Hole U1317A.

\section{Hole U1317B}

The vessel was offset $25 \mathrm{~m}$ southeast of Hole U1317A. After the drill string was spaced out, Hole U1317B was spudded at $1920 \mathrm{~h}$ on 3 May 2005, and a seafloor depth of 809.0 mbrf was established.

Sixteen APC cores advanced to 145.2 mbsf (954.2 mbrf; recovery $=101 \%)$. No tracer material was run in Hole U1317B, and the Tensor orientation tool took measurements from 24.5 to 110.0 mbsf. Overpulls were required on six cores, with $80 \mathrm{klb}$ needed for two of them. At $110.5 \mathrm{mbsf}$, the core barrel had to be drilled over. The coring assembly was switched to XCB for one core, which advanced only $3 \mathrm{~m}$, for a TD in Hole U1317B of 148.2 mbsf (957.2 mbrf). The drill string was pulled clear of the seafloor at $0815 \mathrm{~h}$ on 4 May, officially ending operations in Hole U1317B.

\section{Hole U1317C}

The vessel was offset $25 \mathrm{~m}$ southeast of Hole U1317B. After the drill string was spaced out, Hole U1317C was spudded at $1000 \mathrm{~h}$ on 4 May 2005, and seafloor depth was established at 802.7 mbrf.

Seventeen APC cores advanced to 150.8 mbsf (953.5 mbrf; recovery $=103 \%$ ). No tracer material was run in Hole U1317C, and the Tensor orientation tool took measurements from 19.8 to 95.8 mbsf. Overpulls were required on four cores. The coring assembly was switched to XCB for one core, which advanced only $2.2 \mathrm{~m}$, for a TD in Hole U1317C of 153.0 mbsf (955.7 mbrf). The drill string was pulled clear of the seafloor at $2130 \mathrm{~h}$ on 4 May. The drill string was tripped back to the surface, and the bit cleared the rotary at $2330 \mathrm{~h}$ on 4 May, officially ending operations in Hole U1317C. The bit, seal bore drill collar, and nonmagnetic drill collar were laid out.

\section{Hole U1317D}

The vessel was offset $15 \mathrm{~m}$ south of Hole U1317B. A rotary core barrel (RCB) bottom-hole assembly with an mechanical bit release (MBR) and three stands of drill collars was made up. Hole U1317D was spudded at $0400 \mathrm{~h}$ on 5 May 2005, and seafloor was established at 805.0 mbrf. The RCB was initially run with a center bit, and the hole was drilled ahead to 110.0 mbsf (915.0 mbrf). The center bit was retrieved, and $18 \mathrm{RCB}$ cores advanced an additional $160 \mathrm{~m}$ to a TD of $270.0 \mathrm{mbsf}$ (1075.0 mbrf) at $0420 \mathrm{~h}$ on 6 May (recovery $=64 \%$ ). PFT and microsphere tracers were run on all cores.

Hole U1317D was prepared for logging. A wiper trip was run from bottom to 30 mbsf and back to bottom. During the wiper trip up, overpulls of $70 \mathrm{klb}$ at $242 \mathrm{mbsf}$ and $30 \mathrm{klb}$ at 185 mbsf were experienced. On the wiper trip down, the bit took weight at 222 mbsf. A core barrel was dropped, and the hole was reamed and washed down to TD (270 mbsf). Fill ( $2 \mathrm{~m})$ was circulated out, and hole-cleaning sweep with $30 \mathrm{bbl}$ of sepiolite mud was pumped around. The RCB bit was released and dropped to the bottom. The hole was displaced with $84 \mathrm{bbl}$ of sepiolite mud, and the drill pipe was tripped to the logging depth of 88 mbsf.

The Schlumberger wireline logging sheaves were rigged up, and the triple combination (triple combo) 
tool string was assembled. The logging string was run in the hole and took weight at 246 mbsf. The attempt to work the tools down was not successful, and the hole was logged up from that depth. After the single pass the tools were pulled out of the hole and laid out at $0600 \mathrm{~h}$ on 6 May 2005.

The second logging run was with the Well Seismic Tool (WST). Preparation for this run required following the Marine Mammal Policy for seismic sources. The watch for marine mammals began an hour before the air gun was put through a soft start. The soft start required ramping up the firing pressure to operational levels over a 30 min period. No mammals were sighted. The WST tool string was assembled and run into the hole to 246 mbsf. Check shots were taken at 13 stations on the way up. The signals were good and the WST string was pulled out of the hole and laid out at $2000 \mathrm{~h}$ on 6 May.

The third logging run was with the Formation MicroScanner (FMS)-sonic tool string, which was assembled and run to 246 mbsf. Two logging passes were made from 246 to 88 mbsf. With the logging complete, the string was pulled out of the hole and laid out at $0100 \mathrm{~h}$ on 7 May. The Schlumberger wireline logging sheaves were rigged down, ending the logging operation at $0230 \mathrm{~h}$ on 7 May.

The drill pipe was tripped to surface, and the beacon was released at $0326 \mathrm{~h}$ and recovered. The MBR cleared the rotary at $0430 \mathrm{~h}$ on 7 May, ending operations in Hole U1317D.

\section{Hole U1317E}

Note: Hole U1317E was drilled out of sequence because it was a late add-on that required approvals from both the Integrated Ocean Drilling Program (IODP) safety panel and the Irish government.

The transit from Site U1318 to Site U1317 occurred on 11 May 2005 and took $1.5 \mathrm{~h}$. As the vessel came on site, the thrusters were lowered and the vessel was positioned over the site coordinates. The positioning beacon was dropped at $1138 \mathrm{~h}$ on 11 May. The vessel was offset $50 \mathrm{~m}$ south-southeast of Hole U1317D, and the drill string was spaced out for spudding. Hole U1317E was spudded at $1430 \mathrm{~h}$ on 11 May, and a seafloor depth was established at 792.2 mbrf.

Eighteen APC cores advanced to 158.6 mbsf (950.8 mbrf; recovery $=103 \%$ ). No tracer material was run, and the Tensor orientation tool took measurements from 25.7 to 139.7 mbsf. Overpulls were required on nine cores with $80 \mathrm{klb}$ needed for Core 307-U1317E$17 \mathrm{H}$. Cores $17 \mathrm{H}$ and $18 \mathrm{H}$ had incomplete stroke, and Core $17 \mathrm{H}$ had to be drilled over. The core catcher of Core $17 \mathrm{H}$ held the prize of the hole, the boundary interval where coral growth initiated.
The drill pipe was tripped out of the hole, pulling clear of seafloor at $0100 \mathrm{~h}$ and continuing to the surface. The beacon was released and recovered at 0111 $\mathrm{h}$ on 12 May. The collars were laid out and the rig was secured for transit. The ship was under way to Ponta Delgada, Azores (Portugal), at 0429 h on 12 May, ending operations at Site U1317 (Table T1).

\section{Lithostratigraphy}

Site U1317 is located on the upper flank of Challenger Mound and consists of five holes (U1317A, U1317B, U1317C, U1317D, and U1317E) in water depths ranging from 790 to $840 \mathrm{~m}$. A Pleistocene to lower Miocene succession of sediments was recovered to 268 mbsf. Based on the very distinct change in lithologies and depositional realms, we identified two major sedimentary units. The upper lithostratigraphic Unit 1 (0-130.1 mbsf in Hole U1317A) comprises the upper Pliocene to Pleistocene carbonate mound succession (Fig. F3). The underlying Unit 2 (146.2-270 mbsf in Hole U1317D) consists of the Miocene drift sediments (Fig. F4). The boundary between the two units is a sharp firmground representing a major hiatus as identified by the nannoplankton and planktonic foraminifer biostratigraphy (see "Biostratigraphy") and indicated in the seismic data (see "Physical properties").

Sedimentological highlights include the recovery of the mound base unconformity and the underlying Miocene strata. The mound base from this site is strikingly similar to that of Site U1316. Also noteworthy is the presence of deepwater corals throughout the entire mound succession (lithostratigraphic Unit 1).

The sedimentological descriptions are mainly based on cores from Holes U1317A and U1317D, which were split on board according to IODP standard procedure. Core sections from the other holes (Holes U1317B and U1317E) were split frozen at Gulf Coast Core Repository and Bremen Core Repository to avoid disturbance of the coral-bearing sediments. During drilling operations, only the uppermost five cores of Hole U1317C were split frozen (see "Lithostratigraphy" in the "Methods" chapter).

\section{Lithostratigraphic units}

\section{Unit 1}

Intervals: Sections 307-U1317A-1H through $14 \mathrm{H}-$ 7, $10 \mathrm{~cm} ; 307-\mathrm{U} 1317 \mathrm{~B}-1 \mathrm{H}$ through $16 \mathrm{H}-4$, $52.5 \mathrm{~cm} ; 307-\mathrm{U} 1317 \mathrm{C}-1 \mathrm{H}$ through $17 \mathrm{H}-4$, $102 \mathrm{~cm} ; 307-\mathrm{U} 1317 \mathrm{D}-1 \mathrm{H}$ through 5R-1, 40 $\mathrm{cm}$; and 307-U1317E-1H through 17CC, 22 $\mathrm{cm}$ 
Depths: Hole U1317A: 0-130.1 mbsf, Hole U1317B: 0-143.5 mbsf, Hole U1371C: 0148.0 mbsf, Hole U1317D: 0-146.2 mbsf, and Hole U1317E: 0-155.2 mbsf.

Age: Pleistocene

Facies of the mound succession Unit 1 are divided into floatstone, rudstone, wackestone, packstone, grainstone, sandy clay, and clayey sand. Among these, floatstone and rudstone are the most common (Fig. F5). Grainstone, clayey sand, and sandy clay were rarely found in Unit 1 . The facies are, in general, soft and unlithified but in some intervals partly to well lithified. The carbonate content ranges from 15 to $75 \mathrm{wt} \%$. Cemented nodules are present in Section 307-U1317E-4H-4, 105-125 cm. Drilling breccias commonly occur in the top part of each core.

\section{Floatstone facies}

The floatstone (Fig. F6A) consists of coral fragments embedded in an unlithified greenish gray to dark greenish gray (5GY 5/1-5GY 4/1) wackestone to packstone matrix. Coral fragments $>2 \mathrm{~mm}$ in size were estimated to represent $>10 \%$ of the sediment volume. Corals fragments were randomly oriented and branch lengths of up to $8 \mathrm{~cm}$ are observed at the split surface. The largest coral diameters were recovered from Hole U1317E, closest to the mound summit. We have identified most coral fragments as $L$. pertusa, with minor to rare occurrences of $M$. oculata and Desmophyllum cristagalli. In addition to the coral fragments, the $>2 \mathrm{~mm}$ fraction contains bivalve and gastropod shells, echinoid spines, and other unidentified biogenic components.

The preservation of corals and other large biogenic components in the floatstone facies is dominantly moderate to good. In well-preserved intervals, the theca walls are solid and still show internal structures such as lamination of different aragonite layers. Only the centers of calcification of septa and outer theca show signs of dissolution. But in some intervals, the entire coral skeleton is dissolved and crumbles apart when touched. In addition to dissolution, several coral fragments show signs of bioerosion from clionid sponge Entobia spp.

The matrix of the floatstone consists of unlithified wackestone to packstone dominated by reworked coral material and calcareous ooze of mainly coccolithophorids. Quartz grains are present to abundant throughout the facies. Smear slide analyses show that sponge spicules, glauconite grains, and benthic and planktonic foraminifers are present in the matrix. Dropstones are randomly distributed throughout the facies. The term "floatstone" was used based on the two-dimensional visual description, but a part of this facies is likely to be renamed to "baffle- stone" if an autochtonous appearance of the coral branches is identified by postcruise three-dimensional computed tomography scan analyses.

Throughout the mound succession, the floatstone facies correlates well with maxima in the red/green ratio and magnetic susceptibility (see "Physical properties") as well as minima in sediment lightness (Fig. F3). This can be linked to the carbonate/siliciclastic component ratio. Siliciclastics are generally darker with a higher component in the red spectrum than the dominantly white to gray biogenic carbonates. Therefore, the red/green ratio can be a valid proxy for the terrigenous versus biogenic component content of the sediments. However, a clear correlation was not obtained between the carbonate content of discrete samples and the floatstone facies. This is most likely due to the bimodal nature (corals versus matrix) of the sediments.

The thicknesses of the floatstone packages range from several decimeters to a maximum of $\sim 10 \mathrm{~m}$ (104-114 mbsf) in Hole U1317A. As observed in sediments from Hole U1317A, the unlithified floatstone represents the dominant facies, comprising $\sim 40 \%$ of Unit 1 . Floatstone comprises $70 \%$ of Unit 1 in Hole U1317C (Fig. F5).

\section{Rudstone facies}

The recovered rudstone facies (Fig. F6B) is dominated by coral fragments and minor amounts of shells, echinoid spines, gastropods, and unidentified biogenic components. Colors range from greenish gray to dark greenish gray (5GY 6/1-5GY 4/1). Bioclasts $>2 \mathrm{~mm}$ occur densely packed and form a clastsupported texture with an unlithified packstone, wackestone, or mudstone matrix. Long axes of the bioclasts commonly show a horizontal orientation. Based on visual estimates, coral fragments represent $>20 \%$ of the sediment volume. The carbonate component of the matrix is dominantly nannofossil ooze (mainly coccolithophorids) subordinated by micrite and other skeletal fragments including benthic foraminifers. As noncarbonate components in the matrix, quartz grains are present and glauconite grains are rare.

Coral rudstone composes up to $\sim 50 \%$ of the mound succession. The rudstone packages vary in thickness from several centimeters up to $2 \mathrm{~m}$.

\section{Wackestone facies}

The unlithified to partly lithified coral-bearing wackestone facies (Fig. F6C) consists dominantly of coral fragments $<2 \mathrm{~mm}$ and nannofossils (mainly coccolithophorids). It ranges in color from light greenish gray to greenish gray (5G 7/1-5G 5/1). Smear slide analyses have shown that sponge spi- 
cules and quartz grains are present to common, whereas planktonic and benthic foraminifers are present to rare. The embedded coral fragments that rarely occur in the facies ( $<10 \%$ of the sediment) are strongly dissolved and disintegrate easily.

As opposed to the floatstones, the wackestones correlate to the maxima in the lightness data and minima in the magnetic susceptibility and red/green ratio curves. Wackestones change gradually into floatstones accompanied by increasing content of large coral fragments. These gradual changes can also be identified in the color reflectance data (Fig. F3).

The thicknesses of wackestone intervals vary from several decimeters to a maximum of $4 \mathrm{~m}$ between 97 and 101 mbsf in Hole U1317A. Approximately 15\% of Unit 1 is classified as wackestone facies in Hole U1317A.

\section{Packstone facies}

The packstone facies (Fig. F6D) consists dominantly of sand-sized bioclasts and occasionally includes larger lithoclasts. The spaces between the bioclasts are filled by a micritic matrix. Bioclasts are dominated by coral fragments with minor amounts of shell fragments, echinoid spines, and small gastropods. Smear slide analyses show that nannofossils are the dominant component of the matrix. Siltsized quartz is present to common, while foraminifers, sponge spicules, and glauconite grains are present to rare.

The unlithified packstone facies is characterized by light gray to greenish gray beds of centimeter to decimeter thicknesses in the uppermost $10 \mathrm{~m}$ of the mound succession and in the $2 \mathrm{~m}$ above the mound base (128-130 mbsf) in Hole U1317A. Packstone intervals commonly have sharp erosional bases, fine upward, and change gradually into the overlying facies. The packstone facies accounts for $<2 \%$ of Unit 1 .

\section{Grainstone facies}

The grainstone facies rarely occurs and consists of highly fragmented coral skeletons in beds of few centimeter thicknesses.

\section{Sandy clay and clayey sand facies}

Brown sandy clay and clayey sand are rare in the mound succession. They consist of a mixture of clayey sandy silt with grain-size biogenic components. Occasionally, larger lithoclasts such as dropstones occur (Fig. F7A).

\section{Lithologic cycles}

Recurring lithologic cycles comprise repetition of lighter- and darker-colored strata (e.g., light graylight bluish gray nodular wackestone-packstone gradually changes into the overlain greenish gray coral floatstone; dark greenish gray floatstone and greenish gray rudstone then change again gradually into nodular wackestone-packstone of light graylight bluish gray color) (Fig. F3). Erosional surfaces generally occur on top of the lighter-colored wackestone-packstone facies, with burrowing into the partly lithified layer.

\section{Boundary between upper Pliocene-Pleistocene and Miocene strata}

The boundary between upper Pliocene to Pleistocene strata (Unit 1) and Miocene strata (Unit 2) is represented by a firmground; a consolidated sediment that can be scratched with a knife. It shows a gradual color change in the upper $3 \mathrm{~cm}$ of Unit 2 from grayish green to light greenish gray at the boundary. This erosional horizon at the top of the Miocene silts is overlain by a $2 \mathrm{~cm}$ thick unlithified packstone with abundant benthic foraminifers and small coral fragments in Hole U1317A (Fig. F7B). The packstone is overlain by coral floatstone. This boundary transition occurs in all holes: in Hole U1317A at 130.1 mbsf, Hole U1317B at 143.5 mbsf, Hole U1317C at 148.0 mbsf, Hole U1317D at 148 mbsf, and Hole U1317E at 155.2 mbsf.

\section{Unit 2}

Intervals: Sections 307-U1317A-14H-7, $10 \mathrm{~cm}$, through end of hole; 307-U1317B-16H-4, $52.5 \mathrm{~cm}$, through end of hole; 307-U1317C$17 \mathrm{H}-4,102 \mathrm{~cm}$, through end of hole; 307U1317D-5R-1, $140 \mathrm{~cm}$, through end of hole; and 307-U1317E-17H-CC, $22 \mathrm{~cm}$, through end of hole

Depths: Hole U1317A: 130.1-138.8 mbsf, Hole U1317B: 143.5-151.5 mbsf, Hole U1317C: 148.0-154.3 mbsf, Hole U1317D: 146.4-270 mbsf, and Hole U1317E: 155.2-156.6 mbsf.

Age: early to late Miocene

\section{Siltstone facies}

The upper part of Unit 2 (146.4-197.0 mbsf in Hole U1317D) shown in Figure F7C consists of greenish gray to dark greenish gray (5GY 5/1-5GY 4/1) sandy and clayey silt. This siltstone facies is moderately bioturbated yet contains well-preserved burrows and shows a gradual fining-upward trend to silty clay. Within the facies, the carbonate content varies between 26 and $52 \mathrm{wt} \%$. Glauconite is present throughout the facies.

\section{Sandstone facies}

The underlying sandstone facies (Fig. F7D) consists of moderately bioturbated silty sand with colors from 
greenish gray to dark greenish gray (5GY 5/1-5GY 4/ 1). The sediments contain between 25 and $49 \mathrm{wt} \%$ carbonate. Only the samples from an interval significantly enriched in bivalve shells (231.5-232.4 mbsf, Hole U1317D) contain up to $75 \mathrm{wt} \%$ carbonate.

\section{$X$-ray diffraction matrix classification}

As many as $30 \mathrm{X}$-ray diffraction analyses were made on 26 matrix samples from Unit 1 of Hole U1317A and nine analyses of samples from Unit 2 of Hole U1317D. The mineralogical contents of the matrix sediments in Unit 1 consist primarily of low-magnesium calcite and quartz. The calcite/quartz ratio in the sediments, based on the peak height of the calcite (104) cps line to the quartz (101) cps line, ranges from a high of 3.32 to a low of 0.31. Eighteen of the samples appear to record calcite/quartz ratios of $>1$ (six of these having ratios $>2$ ). No clear relationship has been identified between the described lithology (floatstone, wackestone, etc.) and the calcite/quartz ratio. Aragonite is present in all of the samples and is likely to be derived from corals and to a lesser extent from mollusks. Other mineralogical components, in order of abundance, include illite (detected in all Unit 1 samples), dolomite (detected in all but one sample with a significant amount), and feldspar (detected in 23 samples).

Mineralogic contents of sediments of Unit 2 include quartz, calcite, and illite. Quartz dominates all but two of the nine samples. Dolomite detected in one sample is of either diagenetic or detrital origin. Smear slides indicate that the calcite component of the matrix sediment is primarily made up of nannofossils (mainly coccolithophorids). Quartz, feldspar, and illite are identified as detrital fine sand, silt, and clay.

\section{Discussion}

The succession recovered in Holes U1317A-U1317E is $270 \mathrm{~m}$ thick and spans from the early-middle Miocene to Pleistocene (see "Biostratigraphy"). The oldest cored sediments, drift deposits of early-middle Miocene age, change gradually toward more clay rich intervals that are interpreted to represent relatively low energy environments in the younger Miocene succession. The strata end abruptly in the firmground shown in Figure F7B (Hole U1317A) and are erosively overlain by the upper Pliocene to Pleistocene mound succession. The hiatus between the two successions spans at least 1.65 m.y. by calcareous nannofossil or $1.3 \mathrm{~m} . \mathrm{y}$. by planktonic foraminifer biostratigraphic results from erosion or nondeposition.

The mound initiation phase just above the firmground is represented by interbedded grainstone, floatstone, rudstone, packstone, and wackstone in decimeter thicknesses, all reflecting relatively rapidly changing depositional realms. These observations are contrary to previous reports based on seismic data, which predicted mound nucleation on a distinct and lithified hardground.

This basal interval is followed by several meters thick, facies-specific sediment packages, which represent periods of rapid vertical and probably lateral mound expansion when correlated to the basal coral-bearing unit at Site U1316. This growth phase is dominated by floatstones (Fig. F5) which are tentatively interpreted to represent steady-state conditions between coral growth and background sedimentation. Following this phase, a distinct coral floatstone facies not only thins but also alternates to rudstone, packstone, and wackestone facies in the higher mound succession.

The mound succession shows pronounced recurring cycles on a meter to several meter scale. The cycles generally start from floatstone and change into floatstone interbedded with rudstone to wackestone, in which the corals occur mostly in smaller fragments abraded or transported within the mound system. With regard to mound development, the floatstones represent optimal mound growth phases, in which the corals baffle and stabilize the fine-grained sediments. In contrast, the rudstone may represent periods of enhanced erosion and winnowing. With only visual core description and shipboard analyses, we cannot distinguish if the wackestone facies, in which the coral fragments are only poorly preserved, is a primary sedimentary feature or the product of early diagenesis. The poor coral preservation indicates that diagenetic processes are at least overprinting the sedimentary signal.

The rhythmic recurring cycles can be clearly identified in the red/green ratio of the color reflectance data. Further investigation is needed to understand to what extent these cycles can be linked to climate changes.

\section{Biostratigraphy}

Core catcher samples from each core of Holes U1317A, U1317B, U1317C, and U1317D were examined for nannofossils, and Hole U1317A was examined for planktonic foraminifers in order to provide a shipboard biostratigraphic framework for recovered sediment. In Hole U1317D, additional nannofossil samples were collected at higher resolution from the middle part of the core and examined in order to obtain better constraints for the uniformity and age of the mound base.

Nannofossils are moderately to well preserved in all sediments. Planktonic foraminifers are moderate to 
abundant throughout the hole and their preservation in Hole U1317A is good to moderate.

\section{Calcareous nannofossils}

The lower Pleistocene (0.46-1.22 Ma) is assigned for the upper part of the sediments recovered in Hole U1317A (Section 307-U1317A-1H-CC through Core 8H; 0-73.0 mbsf) (Fig. F8). We designated this age based on the common occurrence of the nannofossil species small Gephyrocapsa (last occurrence [LO] = $1.22 \mathrm{Ma})$ and Pseudoemiliania lacunosa $(\mathrm{LO}=0.46$ Ma) (Table T2). In Sample 307-U1317A-1H-CC, the very abundant occurrence of small Gephyrocapsa indicates that this interval can be older than the top of the small Gephyrocapsa Zone (0.96 Ma; Table T2). From Core 307-U1317A-2H to Section 11H-CC, the abundance of small Gephryrocapsa decreases significantly, and the age assignment for these intervals is tentative.

The lower Pleistocene to upper Pliocene Calcidiscus macintyrei Zone (1.59-1.95 Ma) is assigned for the lower part of lithostratigraphic Unit 1 of Cores 307U1317A-9H through $14 \mathrm{H}$ (73.0-130.0 mbsf). C. macintyrei is common in this interval, and we used its occurrence as the criterion for the age designation of this interval. The LO of this species is $1.59 \mathrm{Ma}$ and designates the top of the C. macintyrei Zone (1.59$1.95 \mathrm{Ma})$. The base of the C. macintyrei Zone (1.59$1.95 \mathrm{Ma}$ ) is defined by the LO of Discoaster brouwerii. In Holes U1317A, U1317B, and U1317C, this species is absent. This age assignment, however, remains tentative because of the presence of significant reworking in several sections (Fig. F9).

In several intervals (Fig. F9), we tentatively identified rare specimens of Emiliania huxleyi, which has an age range of Holocene to $0.26 \mathrm{Ma}$. It is often difficult to accurately identify this species under the light microscope. We decided that these specimens were too rare and questionable to be used as a criterion for age assignment. Further research using scanning electron microscope is needed to the resolve this issue.

The sediment at 130.5 mbsf in Hole U1317A and 145.8-216.7 mbsf in Hole U1317D commonly yields Sphenolithus spp. and Reticulofenestra spp., both of which have well-established LOs at $3.6 \mathrm{Ma}$. The presence of these genera indicates a sedimentary succession age older than late Pliocene. Sphenolithus heteromorphus (13.6-18.2 Ma) and Helicosphaera ampliaperta $(\mathrm{LO}=15.6 \mathrm{Ma})$ occur in many horizons of lithostratigraphic Unit 2, although their occurrences in Hole U1317A are few (Fig. F9). Though not dominant, they are important species that define the age corresponding to early-middle Miocene (15.618.3 Ma). Occurrence of these species was recognized to 216.7 mbsf in Hole U1317D.

\section{Planktonic foraminifers}

We identified several age-diagnostic species in sediments of Hole U1317A (Table T3; see Fig. F14 in the "Site U1316" chapter). The upper part of lithostratigraphic Unit 1 was correlated to the middle-late Pleistocene subtropical and temperate Subzone Pt1b (Berggren et al., 1995a, 1995b) by finding Globorotalia tosaensis in Sample 307-1317A-7H-CC (63.7 mbsf). We assume that this horizon is the LO of G. tosaensis and the bottom of Subzone Pt1b (Fig. F8). Globorotalia inflata was recorded throughout this part.

The mid-latitude Zones SN14 and SN13, as defined by Jenkins $(1985,1993)$, were applied to the lower part of lithostratigraphic Unit 1 in Hole U1317A. These zones correspond to the lower Pleistocene and upper Pliocene by presence of Globorotalia crassaformis (Figs. F8, F10); however, we could not separate Zones SN13 and SN14 because the sediment in Hole U1317A poorly yields the index species. The base of Zone SN14 is defined by the first appearance of Globorotalia truncatulinoides, but this species was not found except in Sample 307-1317A-1H-CC (6.4 mbsf). The age of lithostratigraphic Unit 2 in Hole U1317A is assigned to Miocene (Biozones M1-M14) (Fig. F8) by the occurrence of Globoquadrina dehiscens (Fig. F10).

The planktonic foraminifer assemblage from Hole U1317A is poor in cool- to temperate-water taxa, such as Globigerina bulloides and Neogloboquadrina incompta. A typical cold-water species, Neogloboquadrina pachyderma, was only identified from Sample 307U1317A-5H-CC (44.7 mbsf) (Fig. F10). Lithostratigraphic Unit 1 commonly yields warmer water taxa $G$. inflata, Globorotalia scitula, and Orbulina universa. These assemblages indicate warmer conditions than those of Unit 1 in Hole U1316A.

\section{Benthic foraminifers}

Sediments from Hole U1317A yield similar assemblages of benthic foraminifers as sediments from Hole U1316A (Figs. F17, F18 in the "Site U1316" chapter). A major difference is the rare occurrence of shallow-water species, such as Elphidium excavatum and Islandiella norcrossi (Fig. F11), which are common in lithostratigraphic Unit 1 in Hole U1316A. Species associated with cold seepage, Bulimmina marginata and Bulimmina sp. A, are less common than in Hole U1316A (Fig. F18 in the "Site U1316" chapter).

\section{Discussion}

An overview of the biostratigraphy in Holes U1317A and U1317D indicates that lithostratigraphic Unit 1 is Pleistocene and contains abundant reworked Late 
Cretaceous nannofossils (Table T4). The age of the top of lithostratigraphic Unit 2 is older than early Pliocene $(3.6 \mathrm{Ma})$ by calcareous nannofossils and Miocene by planktonic foraminifers (Fig. F8). Unit 2 below Sample 307-U1317D-9R-CC (184.0 mbsf) is early-middle Miocene based on calcareous nannofossil biostratigraphy.

There is an inconsistency in age assignment of the upper part of Unit 1. Planktonic foraminfer biostratigraphy indicates an age younger than 0.65 Ma was assigned for sediments above Sample 307U1317D-7H-CC, yet based on calcareous nannofossils, it is much older (0.96-1.22 Ma) (Fig. F8). The reason for this inconsistency between calcareous nannofossil age and planktonic foraminifer age is still uncertain, and further research is necessary.

\section{Paleomagnetism}

Shipboard paleomagnetic measurements were conducted on cores from Holes U1317A, U1317B, U1317C, U1317D, and U1317E. Alternating-field (AF) demagnetization of natural remanent magnetization (NRM) was conducted up to $20 \mathrm{mT}$ in $5 \mathrm{mT}$ steps on Section 307-U1317A-1H-1. Based on this demagnetization experiment (Fig. F12), cores from Holes U1317B, U1317C, and U1317D were demagnetized at 10 and $15 \mathrm{mT}$. Cores from Hole U1317E were demagnetized at 2, 5, 7, 10, and $15 \mathrm{mT}$. NRM and magnetization after AF demagnetization were measured on whole-round sections because Holes U1317B, U1317C, U1317D, and U1317E remained closed for further macrotomographic analyses and freezing before opening. A comparative test on whole rounds and archive halves of cores from Site U1316 (see "Paleomagnetism" in the "Site U1316" chapter) showed that measuring whole-round sections does not adversely affect the measurements. On the contrary, for core sections with very weak intensities (i.e., carbonate-rich sediments from lithostratigraphic Unit 1), whole-round sections provide more precise information because the entire mass of material is measured and is undisturbed by section splitting. Moreover, intensities measured on wholeround sections can be better used for normalization by magnetic susceptibilities because the same material is measured (see "Paleomagnetism" in the "Site U1316" chapter). Discrete samples were taken on the working halves in Hole U1317A for subsequent shore-based magnetostratigraphic and rock magnetic studies.

As at Site U1316, inclination data clustered around $\sim 66^{\circ}$ in the uppermost sections (0-62 mbsf) in Holes U1317A, U1317B, U1317C, and U1317E (Fig. F13). Small excursions to lower values can be observed within this uppermost zone. Below $63,62,53$, and 56 mbsf in Holes U1317A, U1317B, U1317C, and $\mathrm{U} 1317 \mathrm{E}$, respectively, the inclinations have a tendency to decrease to negative values, which could indicate the transition to reversed polarity. Normal polarity inclinations are generally observed between 78 and 92 mbsf in Hole U1317A, 81.8 and 96.5 mbsf in Hole U1317B, 82.3 and 100 mbsf in Hole U1317C, and 75 and 102 mbsf in Hole U1317E. These normal inclinations are underlain by predominantly reversed inclinations. Normal inclinations are then observed in the following intervals to the hiatus at the base of the mound: 101-130.5 mbsf in Hole U1317A, 105.4-142 mbsf in Hole U1317B, 111-150 mbsf in Hole U1317C, and 108-157 mbsf in Hole U1317E. From 146 to 205 mbsf in Hole U1317D, the inclination data are highly scattered but predominantly normal (Fig. F14). Deeper than 205 mbsf, the inclination values show less variation and center at $\sim 66^{\circ}$. We attribute the transition from higher to lower variability to a lithologic overprint. A mainly sandy to clayey silt facies changes to silty sands over these depths (see "Lithostratigraphy"). The inclination data must be interpreted carefully because some bias and background noise (due to the motion of the ship) in the cryogenic magnetometer and a magnetic overprint gathered during drilling may influence the measurements, resulting in an artificial magnetic inclination pointing downward. This problem may be especially severe in carbonate-rich sediments that have low magnetic intensities.

Declination data could only be corrected by Tensor tool measurements for Cores 307-U1317A-3H through $7 \mathrm{H}, 307-\mathrm{U} 1317 \mathrm{~B}-3 \mathrm{H}$ through $12 \mathrm{H}, 307-$ U1317C-1H through $11 \mathrm{H}$, and 307-U1317E-3H through $15 \mathrm{H}$. Declination data could not be corrected for Hole U1317D because of RCB drilling.

The low magnetic intensities and susceptibilities are typical for carbonate-rich sediments. Carbonate minerals in all holes are responsible for the diamagnetic character of the susceptibility measurements. The weakest intensity values are within the range of the noise level of the cryogenic magnetometer. A normalization of the intensities was carried out by dividing intensities by magnetic susceptibilities. Some normalized intensity peaks could be recognized (Fig. F15).

Correlation to the geomagnetic polarity timescale was limited by artificial magnetic overprints gathered during drilling, a major hiatus at the mound base identified in the biostratigraphic and sedimentological data (see "Lithostratigraphy" and "Biostratigraphy"), limitations in the reliability of the directional data from low-intensity measurements, and diamagnetic overprints in the mound sedi- 
ments. However, a first tentative magnetostratigraphic framework could be constructed (Fig. F13) but must be interpreted carefully.

The predominantly normal polarities above $62 \mathrm{mbsf}$ in Hole U1317A, 61 mbsf in Hole U1317B, 53 mbsf in Hole U1317C, and 56 mbsf in Hole U1317E probably belong to the Brunhes Chron (C1n), which has an age $<0.78 \mathrm{Ma}$. The negative inclination values below these depths correspond with a reversal period, probably the Matuyama Chron (C1r.1r). We tentatively interpret the zone between 78 and $92 \mathrm{mbsf}$ in Hole U1317A, 81 and 96 mbsf in Hole U1317B, 82 and 100 mbsf in Hole U1317C, and 75 and 102 mbsf in Hole U1317E as the normal Jaramillo Chron (C1r.1n), with an age from 0.990 to $1.070 \mathrm{Ma}$. This is generally consistent with the biostratigraphic interpretation (see "Biostratigraphy"). The underlying zone would therefore be associated with Subchron C1r.2r, which is characterized by an age $>1.070 \mathrm{Ma}$ but $<1.770 \mathrm{Ma}$. A small erosion surface at the base of this zone is observed in the sedimentology (see "Lithostratigraphy"). Below this interval, positive inclinations are observed pointing out a normal polarity chron that would correspond with the Olduvai Chron (C2n). The sediments in this chron should be $<1.950 \mathrm{Ma}$; however, an alternative may be to interpret the two normal polarity intervals above the mound base as the Olduvai Chron (C2n; 1.770$1.950 \mathrm{Ma})$ and the Gauss Chron (C2An.1n; 2.60-3.04 Ma).

Measurements on discrete samples must be carried out to improve and confirm this first magnetostratigraphic interpretation.

\section{Geochemistry and microbiology Geochemistry}

A total of 59 interstitial water samples were taken from Holes U1317A, U1317D, and U1317E (31, 20, and 8 samples, respectively). Sampling of Hole U1317A was completed at a depth of 137 mbsf and the sampling of Hole U1317D began at 130 mbsf in order to provide a complete depth profile with slight overlap. Sampling of Hole U1317E was restricted to the upper four cores. Two interstitial water samples per core were collected from Hole U1317A because interstitial water recovery was low, except from Cores 307-U1317A-17X and 18X, where one interstitial water sample was taken. Two interstitial water samples per core were collected from Holes U1317D and U1317E, except from Cores 307-U1317D-3R through $6 \mathrm{R}$, where one interstitial water sample per core was collected. The APC was used in Holes U1317A and U1317E, and the RCB was used in Hole U1317D.
Syringe samples were collected for gas chemistry. One sample per core was collected for shipboard safety analyses of dissolved methane from Holes U1317A, U1317D, and U1317E, and one sample per core was taken from Hole U1317B from Cores 307$\mathrm{U} 1317 \mathrm{~B}-1 \mathrm{H}, 2 \mathrm{H}, 4 \mathrm{H}$, and $13 \mathrm{H}$ through $17 \mathrm{X}$ for a total of 62 samples $(19,8,18$, and 17 samples from Holes U1317A, U1317B, U1317D, and U1317E, respectively). One sample per core was collected for analysis of total methane (both dissolved and adsorbed) from Holes U1317A and U1317D for a total of 31 samples (15 and 16, respectively).

\section{Interstitial water and gas}

As at Site U1316, variations in interstitial water composition at Site U1317 are driven principally by microbially mediated reactions, diffusion of chemical species resulting from diagenesis at depths greater than those sampled, and varying rates of sediment burial (Table T5).

The concentration of Sr (Fig. F16A) increases from $212 \mu \mathrm{M}$ at $1.4 \mathrm{mbsf}$, the shallowest depth sampled, to a maximum of $2320 \mu \mathrm{M}$ at $\sim 120 \mathrm{mbsf}$. From 1.4 to 50-60 mbsf, the curvature of the profile is concave downward. The concave-downward profile is accentuated in Hole U1317E. Both profiles imply Sr input to the pore fluids, possibly the result of aragonite diagenesis. Below 50-60 mbsf, Sr increases linearly, implying a diffusion-controlled profile, to a maximum concentration of $2320 \mu \mathrm{M}$ at $\sim 120$ mbsf. This maximum is likely the result of aragonite diagenesis. From 110 to $140 \mathrm{mbsf}$, the $\mathrm{Sr}$ concentration decreases linearly to $\sim 1150 \mu \mathrm{M}$ at $170-180$ mbsf and then slightly increases with increasing depth to $>1200 \mu \mathrm{M}$ at the bottom of the hole.

In contrast to Site U1316, Li and B (Fig. F16B, F16C) do not covary with Sr. They do covary linearly with each other, however, and both $\mathrm{Li}$ and B concentrations increase nearly linearly from the top to the bottom of each hole, implying diffusion. The higher concentrations of these elements at depth are most likely the result of silicate diagenesis. Li and B increase from values in Hole U1317A at 1.4 mbsf of 40 $\mu \mathrm{M}$ and $547 \mu \mathrm{M}$, respectively, to a maximum near the bottom of Hole U1317D at 250 mbsf of $363 \mu \mathrm{M}$ and $2150 \mu \mathrm{M}$, respectively. An offset in the values between Holes U1317A and U1317D is prominent and is most likely the result of either lateral variation in the pore fluid chemistry between the two holes or a sampling/analytical artifact. Site U1317 is on the slope of the mound and there are significant differences in depth to seafloor between the holes (815 meters below sea level [mbsl] for Hole U1317A and 794 mbsl for Hole U1317D). It is unknown whether the concentration gradients follow the same con- 
tours as the bathymetry; however, linking offsets in the geochemical profile to lateral stratigraphic variations requires that a similar depth offset be found in the profiles of each chemical species. This pattern is not observed (profiles described below); therefore, it is more likely that the offset is a result of error in the concentration measurement. These elements were diluted and analyzed on the inductively coupled plasma-atomic emission spectrometer (ICP-AES) from the same subsample. Variations in the calibration curve and the diluent between the ICP-AES subsamples from Holes U1317A and U1317D will lead to an offset in the concentration values.

Chlorinity behaves conservatively and the profile reveals a gradual increase in chlorinity with depth (Fig. F16D). It should be noted that Hole U1317E chlorinity measurements were determined by anion chromatography, rather than by titration. Variations in chlorinity may indicate errors introduced during sampling, loss of water associated with alteration of volcanic ash, or differences caused by the burial of different water masses during different levels of glaciation. The seawater in this region is dominated by high-salinity MOW, and the offset in chlorinity from 1.4 to $\sim 30$ mbsf may reflect variations in hydrography. A change in salinity of 1 psu would lead to a change in chlorinity of $15.6 \mathrm{mM}$.

$\mathrm{pH}$ is highest (7.69) at $1.4 \mathrm{mbsf}$, decreases to $~ 7.3$ at 30-40 mbsf, and remains constant at $\sim 7.3$ to the bottom of the hole. This profile results from the diffusion of seawater into pore fluids that are influenced by microbial oxidation of organic carbon and buffered by carbonate phases (Fig. F16E). The profiles of dissolved inorganic carbon (DIC) and alkalinity are similar to one another (Fig. F17A, F17B). Both profiles increase with increasing depth from $1.4 \mathrm{mbsf}$ and have coinciding maxima that extend from $~ 140$ to 170 mbsf. Below 170 mbsf, both DIC and alkalinity decrease with depth. Concentrations of both DIC and alkalinity are higher $(\sim 3 \mathrm{mM})$ in Hole U1317E, as compared to Hole U1317A.

Dissolved methane concentrations are low $(<0.2 \mu \mathrm{M})$ to a depth of 132 mbsf in Hole U1317A and 148 mbsf in Hole 1317D (Fig. F17F; Table T6). Concentrations increase steeply below $132 \mathrm{mbsf}$, reaching $6.66 \mu \mathrm{M}$ by $266 \mathrm{mbsf}$. This profile reflects methane production and diffusion from the deeper Miocene sediments and anaerobic methane oxidation occurring at $~ 140$ mbsf. Adsorbed methane, the dissolved methane subtracted from the total methane in samples treated with $1 \mathrm{M} \mathrm{NaOH}$, is below the analytical detection limit throughout most of this hole (Fig. F17G). Dissolved ethane remains below the detection limit until $132 \mathrm{mbsf}$ in Hole U1317A and 152 mbsf in Hole U1318D (Fig. F17H). Like methane, it generally increases with increasing depth, and the change in gradient at $\sim 140$ mbsf implies anaerobic consumption. The considerable scatter in the gas data appears to be an artifact of RCB drilling and the protocol involved with sampling fairly indurated sediments.

Ammonium (Fig. F17I) also increases with depth with a slight concave-upward shape from $30.5 \mu \mathrm{M}$ to a maximum of $>2.6 \mathrm{mM}$ at 220 mbsf indicating microbial respiration of nitrogen-containing organic matter. Below 220 mbsf, it decreases in concentration to $2.46 \mathrm{mM}$ at $266 \mathrm{mbsf}$ and is most likely controlled by diffusion.

Dissolved sulfate (Fig. F17C) is $27.3 \mathrm{mM}$ at $1.4 \mathrm{mbsf}$ and decreases to below its analytical detection limit near 170-180 mbsf. The double (because of an inflection point in the profile $\sim 50-60 \mathrm{mbsf}$ ) concavedownward curvature of the profile is a result of sulfate removal by bacterially mediated sulfate reduction. The decrease in sulfate is particularly striking in Hole U1317E, where sulfate decreases from seawater values at $1.4 \mathrm{mbsf}$ to $<15 \mathrm{mM}$ at $28 \mathrm{mbsf}$. A zone of apparent sulfate consumption, as indicated by the concave-downward shape of the sulfate profile between 150 and 190 mbsf, corresponds to the depths of a steep increase in methane concentration (Fig. F17C, F17F). The profiles imply that sulfate reduction coupled to anaerobic methane oxidation is occurring over this broad $50 \mathrm{~m}$ interval of sediments. The oxidation of methane and the reduction of sulfate increase the DIC and the alkalinity over this interval, potentially driving carbonate precipitation.

Dissolved Mn and dissolved Fe have maxima of 3.5 $\mu \mathrm{M}$ and $38 \mu \mathrm{M}$, respectively, at 1.4 mbsf and drop sharply at 4.9 mbsf to below analytical detection limit (Table T5).

Barium concentrations are below $0.5 \mu \mathrm{M}$ until $~ 100$ mbsf, at which point they increase to $11.2 \mu \mathrm{M}$ at the bottom of Hole U1317D (266 mbsf) (Fig. F17J). Ba concentrations are controlled by sulfate concentrations. Decreasing sulfate promotes the dissolution of barite $\left(\mathrm{BaSO}_{4}\right)$, adding $\mathrm{Ba}$ to the pore fluid.

Calcium concentrations (Fig. F17D) range from 10.5 $\mathrm{mM}$ at 1.4 mbsf to a broad local maximum of $\sim 11.5$ $\mathrm{mM}$ at depths ranging from $\sim 20$ to 50 mbsf. The concomitant rise in Sr over this same interval suggests the broad increase in $\mathrm{Ca}$ is related to aragonite dissolution. In contrast, Ca exhibits a $2 \mathrm{mM}$ drop in concentration over the same interval in Hole U1317E. This drop in Ca concentration, coupled with a rise in Sr, suggests mineral-controlled diagenesis of aragonite, such as the inversion of aragonite to calcite, rather than dissolution. Below this interval, calcium concentrations decrease to $\sim 9-10 \mathrm{mM}$ at 100 mbsf, forming another broad local minimum 
in the profile from $\sim 100$ to 170 mbsf and then increase to $12-13 \mathrm{mM}$ toward the bottom of the hole.

Magnesium concentrations (Fig. F17E) decrease from near-seawater values of $>51 \mathrm{mM}$ at $1.4 \mathrm{mbsf}$ to $\sim 35$ $\mathrm{mM}$ at $\sim 120$ mbsf and then gently decrease to $\sim 30$ $\mathrm{mM}$ at the bottom of Hole U1317D (266 mbsf). The $\mathrm{Mg}$ profile shows a similar trend with depth as sulfate, including an inflection point in its curvature at 50-60 mbsf forming a double concave-downward profile. The $\mathrm{Mg}$ decrease is more accentuated in Hole U1317E. From 140 to $170 \mathrm{mbsf}$, the $\mathrm{Mg}$ profile straightens and decreases linearly with depth, appearing to be diffusion controlled to the bottom of the hole. The concave-downward $\mathrm{Mg}$ profile from 1.4 to $~ 140-170$ mbsf indicates $\mathrm{Mg}$ removal, possibly because of diagenetic carbonate formation.

Below 140-170 mbsf, alkalinity, DIC, and Mg decrease, Ca increases, and sulfate remains depleted. The alkalinity, DIC, Mg, and Ca profiles appear diffusion controlled and the net loss of $\mathrm{Mg}$, DIC, and alkalinity, in contrast to the net gain in $\mathrm{Ca}$, implies some degree of dolomitization at depth, although the addition of $\mathrm{Ca}$ from the breakdown of calciumrich silicates at depth can also drive carbonate precipitation and contribute to a decrease in alkalinity, $\mathrm{DIC}$, and $\mathrm{Mg}$.

\section{Sediments}

Carbonate is present at significant levels throughout the site. In the full $260 \mathrm{mbsf}$ profile, it scatters around an average of $45.4 \mathrm{wt} \%$ and principally ranges between 30 and $60 \mathrm{wt} \%$ (Table T7). The depth profile for Hole U1317A is shown in Figure F18.

\section{Microbiology}

\section{Whole-round core and catwalk sampling}

Whole-round cores (WRCs) were taken from Holes U1317A and U1317D for shore-based work. A $2 \mathrm{~m}$ section from each core was selected on the catwalk. After removal of the interstitial water sample together with a variety of small syringe samples, the remainder was taken directly from the catwalk to cold storage at $10^{\circ} \mathrm{C}$, where WRC sections were cut and packed. Appropriately packed samples were stored at either $+4^{\circ} \mathrm{C}$ or $-80^{\circ} \mathrm{C}$. The distribution and packing/ storing requirements of all samples and their sample codes are given in Figures F19 and F20. A total of $692 \mathrm{WRC} /$ syringe samples were obtained.

\section{Total prokaryote enumeration}

Samples of $1 \mathrm{~cm}^{3}$ plugs for total prokaryote enumeration were taken during core processing on the catwalk from Holes U1317A (16 samples between the near surface and $136.81 \mathrm{mbsf}), \mathrm{U} 1317 \mathrm{D}$ (16 samples between 129.90 and $265.96 \mathrm{mbsf}$ ), and U1317E (5 samples between 1.35 and $38.15 \mathrm{mbsf}$ ). All the samples in Holes U1317D and U1317E were stored for later, shore-based processing.

Prokaryotes were present in all samples studied to a depth of 136.81 mbsf (Fig. F21). The largest population was $1.52 \times 10^{7}$ cells $/ \mathrm{cm}^{3}$ at 4.85 mbsf (Sample 307-U1317A-1H-3, 185-190 cm) and the smallest population was $1.86 \times 10^{6} \mathrm{cells} / \mathrm{cm}^{3}$ at $68.35 \mathrm{mbsf}$ (Sample 307-U1317A-8H-3, 185-190 cm). The detection limit was estimated at $2 \times 10^{5}$ cells $/ \mathrm{cm}^{3}$ based on calculations on a single membrane filter, and for each sample duplicate filters were used to provide a measure of variability. Where a zero count occurred, the prokaryote population was estimated by combining the data from both membranes and treating it as one subsample. This provides the only possible estimate of the population size in such samples but does not allow any measure of variability.

The overall depth profile of cell numbers per cubic centimeter initially follows the lower prediction limits of the trend observed at other Ocean Drilling Program sites (Parkes et al., 2000), with a prokaryote population a factor of three times smaller than expected indicating that in the upper $30 \mathrm{~m}$ this is a low-activity site. Between $\sim 30$ and 70 mbsf (Samples 307-U1317A-4H-4, 185-190 cm, and 8H-3, 185-190 $\mathrm{cm})$ there is an increase in cell numbers. Although this increase is small (a doubling of the population), it is persistent and accompanied by a significant rise in the dividing cell numbers indicating the population growth is real. It is not yet clear why this bulge in the prokaryote population occurs. From 68.35 mbsf (Sample 307-U1317A-8H-3, 185-190 cm) downhole, there is a gradual increase in the cell numbers toward the expected profile, after which they decrease gradually in line with it. At 125.25 mbsf (Sample 307-U1317A-14H-3, 185-190 cm), however, cell numbers show a steady increase to 7.86 $\times 10^{6}$ cells $/ \mathrm{cm}^{3}$, approximately doubling the population size and giving the second highest count in this hole. This increase is concomitant with the appearance of significant methane, albeit at relatively low concentrations, and suggests methane oxidation and/or methanogenesis is occurring at these depths. Additionally, this increase in cell numbers is supported by a steady rise in dividing cell numbers, indicating active population growth. It is suspected that the initial increase in cell numbers and dividing cell numbers at 125.25 mbsf is associated with methane oxidation, hence the absence of methane at this particular depth. This hypothesis will be tested by measurements of methane oxidation activity in later shore-based work. 


\section{Contamination tests}

\section{Perfluorocarbon tracer}

PFT was added continuously to the drilling fluid during coring of Holes U1317A and U1317D to evaluate the penetration depth of the drill mud into the core material. Subcores of $5 \mathrm{~cm}^{3}$ were taken between the center and the periphery from the bottom cut end of each microbiology (MBIO) section adjacent to the interstitial water WRC. In Hole U1317D, an additional subcore was taken from the outer core section (interface between liner and core). The delivery of PFT to the drill mud was again confirmed by analysis of several drill mud samples (Table T8). Air samples from the catwalk and the laboratory were collected to assess potential PFT background concentrations from the analytical procedures. All air samples tested negative for PFT (Table T8). The gas chromatograph system was tested by injecting $1 \mathrm{~mL}$ of PFT-free air. Even after a PFT standard, the subsequent blank run shows no PFT signal and indicates that no background signal is present from the analytical procedure.

The first 14 cores of Hole U1317A were cored using the APC system. All inner core subsamples were negative for PFT. Sections 307-U1317A-17X-1 and 18X-1 were cored with the XCB system, resulting in a greater disturbance of core integrity. Whereas the interior of Section 307-U1317A-17X-1 was negative, Section 307-U1317A-18X-1 revealed trace amounts of PFT, possibly caused by the XCB coring process.

Hole U1317D was drilled exclusively with the RCB drilling technique. Thus, the outer core surface is always in contact with drill fluid and so it is not surprising that in almost all cores taken, the outer core surface was contaminated with drill fluid (Table T8). However, with one exception (Section 307-U1317D10R-1), the interior of the sample material did not have a PFC drill mud signal, indicating an intact and contamination-free core interior. Cores taken using RCB drilling will need to be inspected for fractures that allow the intrusion of drill mud prior to their use in MBIO. This may also be an explanation for the occurrence of PFT in Section 307-U1317D-10R-1.

\section{Particulate tracer}

Fluorescent microspheres were deployed in all cores from which MBIO samples were taken in Holes U1317A and U1317D. Subcores of $5 \mathrm{~cm}^{3}$ were taken from the bottom cut end of each MBIO section adjacent to the interstitial water WRC. Microspheres were detected in six samples from Hole U1317A and in zero samples from Hole U1317D (Table T8). Contamination levels were generally higher in cores from Site U1317 than from Site U1316; however, contamination levels are still likely to be very low given that the original microsphere suspension contained 7,000,000 microspheres per microliter. The number of microspheres detected in Sample 307$1317 \mathrm{~A}-3 \mathrm{H}-3,20.85-20.9 \mathrm{~cm}\left(993 / \mathrm{cm}^{3}\right)$, is still only equivalent to the estimated minimum penetration of 0.14 nannoliters of drill fluid per cubic centimeter, or $0.14 \mathrm{ppm}$. The relatively high numbers of microspheres observed in the upper part of Hole U1317A is probably due to the nature of the core material, which frequently contained pieces of coral. This would disrupt the integrity of the core allowing ingress of drill fluids. Interestingly, no microspheres were detected in Hole U1317D. This frequently is the case with RCB cores, as the sediments are much harder and more consolidated, therefore preventing drill fluid penetration.

\section{Physical properties}

Physical properties measured on the cores of Site U1317 include magnetic susceptibility measured with the "Fast Track" multisensor core logger and multisensor track (MST), gamma ray attenuation (GRA) density, natural gamma radiation (NGR), and $P$-wave velocity measured with the MST $P$-wave logger (PWL) and at discrete positions on split cores with the $P$-wave sensor (PWS), moisture and density (MAD), and thermal conductivity. Good results were obtained with all core logging sensors, except for the PWL measurements that became unreliable due to the high coral content. The use of XCB or RCB drilling also precluded PWL measurements because the air buffer between the sediment and core liner blocked the acoustic signal. Shear strength measurements were only carried out on the upper sections (0-120 mbsf), as below the mound base the sediment became too indurated.

The holes at this site were drilled in the upper flank of the mound going upslope from Hole U1317A to U1317C, with the deeper Hole U1317D just south of the profile between Holes U1317B and U1317C. Hole U1317E was drilled on top of the mound and penetrated the mound base (Fig. F22). Continuous physical property records have been produced due to the almost $100 \%$ recovery at Site U1317 inside the mound facies (lithostratigraphic Unit 1). Recovery was less complete, however, in RCB-cored Hole U1317D, which penetrated the units below the mound base. The physical property records demonstrate similar trends in variations and cycles in all holes. Nevertheless, no composite depth profile was made because of the significant lateral variation in the stratigraphic thickness of the layers in the different holes. 
Based on the seismic stratigraphy and sedimentology (see "Lithostratigraphy"), the Site U1317 succession was divided into two units. Physical property (PP) Unit PP1 is a Pleistocene rudstone-wackestone unit that comprises the mound itself (Hole U1317A, 0130 mbsf and Hole U1317D, 0-146 mbsf). Unit PP2 is siltstone below the mound base. Figures F22, F23, F24, F25, and F26 show the physical property measurements of the different holes at Site U1317.

\section{Magnetic susceptibility}

The values of magnetic susceptibility are in general very low throughout the cores. Nevertheless, two major units can be identified based on the absolute values of the magnetic susceptibility. Magnetic susceptibility is slightly higher in physical property Unit PP1 (the upper part) than in Unit PP2 (the lower part) and shows a few peaks. Unit PP1 coincides with mound lithostratigraphic Unit 1 (see "Lithostratigraphy"). In Unit PP2, magnetic susceptibility values are very low and show some sawtooth variations. The average value for magnetic susceptibility in Unit PP1 is $\sim 6 \times 10^{-5}$ SI with peaks of $\sim 40 \times$ $10^{-5}$ SI (Figs. F22, F23, F24, F25, F26). In Unit PP2, the magnetic susceptibility drops to a background signal of $\sim 3 \times 10^{-5}$ SI with peak values of $\sim 12 \times 10^{-5}$ SI (Fig. F25). Three narrow peaks have been observed in Unit PP1 at $\sim 1,8$, and 21 mbsf. This pattern is observed in all holes. Between 21 and 80 mbsf, the values are continuously low with occasional episodes of minor high-frequency variability. At $\sim 20-30 \mathrm{~m}$ above the mound base, an increase in magnetic susceptibility is observed before the values drop toward the mound base. The mound base itself has relatively high values. In Unit PP2, the magnetic susceptibility is very low, but troughs and peaks in the curves appear cyclic.

\section{Natural gamma radiation}

In Hole U1317A on the flank of the mound, 10 NGR cycles have been identified. Toward the crest of the mound, 11 cycles appear (Figs. F22, F23, F24, F25, F26). The peaks in NGR seem to coincide with floatstones and the lows with wackestones containing more coral fragments (see "Lithostratigraphy"). These cycles can be correlated but do not show the same thickness across the holes because of their different locations along the transect from the slope to the top of the mound. Below the mound base in physical property Unit PP2, the values are slightly higher than in Unit PP1 and show higher-frequency variations. The parallel trend of the NGR and the magnetic susceptibility curve in Unit PP1 is remarkable and probably reflects the contribution of clay in the sediments.

\section{Gamma ray attenuation, bulk density, and porosity}

Both GRA corrected density and MAD bulk density measurements display parallel trends. MAD measurements were obtained only from Holes U1317A and U1317D. GRA densities deduced from the MST are corrected in the unconsolidated section of the cores in the mound facies according to the equation described in "Physical properties" in the "Methods" chapter. The overall pattern shows a gradual increase in density throughout the core. The largest increase in density is observed at the mound base. In physical property Unit PP1, density decreases from $2 \mathrm{~g} / \mathrm{cm}^{3}$ at the surface to $1.7 \mathrm{~g} / \mathrm{cm}^{3}$ at $\sim 14$ mbsf. Density increases again to $2 \mathrm{~g} / \mathrm{cm}^{3}$ at $\sim 20 \mathrm{mbsf}$. Density values increase gradually to $60 \mathrm{mbsf}$ and remain stable to 100 mbsf. Values increase sharply at the mound base. The upper part of physical property Unit PP2 has a density of $\sim 2.1 \mathrm{~g} / \mathrm{cm}^{3}$ and drops at the base to $1.7 \mathrm{~g} / \mathrm{cm}^{3} \sim 15 \mathrm{~m}$ below the mound. The porosity is calculated to be $\sim 50 \%$ in Unit PP1 and $~ 40 \%$ in Unit PP2.

\section{Shear strength}

Shear strength measured with the Torvane apparatus in Hole U1317A shows the following trend:

1. An increase from $\sim 0$ to $\sim 7 \mathrm{~kg} / \mathrm{m}^{2}$ in the upper 60 mbsf.

2. A decrease between 60 and 75 mbsf with a high variability between $0-8 \mathrm{~kg} / \mathrm{m}^{2}$.

3. A drop to $1 \mathrm{~kg} / \mathrm{m}^{2}$ in a narrow interval of $5 \mathrm{~m}$ between 70 and 75 mbsf.

Between 95 and 102 mbsf, the shear strength decreases gradually from 7 to $1 \mathrm{~kg} / \mathrm{m}^{2}$. The values increase gradually from 1 to $8 \mathrm{~kg} / \mathrm{m}^{2}$ in the $102-108$ mbsf intervals and drop sharply at $\sim 115$ and 120 mbsf just above the mound base.

\section{P-wave velocity}

Although the acquisition of PWL data was problematic at this site, there are still trends that can be derived from the data obtained and from the PWS data collected in Hole U1317A. The sonic velocity drops to $1600 \mathrm{~m} / \mathrm{s}$ and remains constant between 20 and 55 mbsf. Between 60 and 80 mbsf, higher velocities have been measured (up to $1800 \mathrm{~m} / \mathrm{s}$ ), which coincide with floatstones (see "Lithostratigraphy"). The velocity then increases toward the mound base to $1750 \mathrm{~m} / \mathrm{s}$ (Fig. F22). Below the mound base in physical property Unit PP2, the velocity falls to $\sim 1600 \mathrm{~m} / \mathrm{s}$ (Fig. F25). In the lower part of Unit PP2, clear peaks can be recognized with speeds of $\sim 2300 \mathrm{~m} / \mathrm{s}$ with values of $1800 \mathrm{~m} / \mathrm{s}$ between peaks. About eight inter- 
vals of high PWS peaks have been identified in Unit PP2.

The $P$-wave velocity curve parallels the density and NGR of physical property Unit PP2 in Hole U1317D.

\section{Thermal conductivity and in situ temperature measurements}

The deployment of the advanced piston corer temperature (APCT) tool provided insight into the subsurface temperature distribution. Three discrete temperature measurements in Hole U1317A were taken at 25.5, 63.5, and 111.0 mbsf (Fig. F27). The temperature measurement at $25.5 \mathrm{mbsf}$ is high in comparison to the other measurements at the site and is considered an outlier. The data show temperature gradients of $50^{\circ} \mathrm{C} / \mathrm{km}$, which is a normal gradient for a passive continental margin.

In Hole U1317A, thermal conductivity values increase with depth. Thermal conductivity is primarily dependent on variations in sediment bulk density, which is related to other sediment physical properties such as velocity. Thus, these data sets are well correlated (Fig. F28).

\section{Interpretation}

Based on the overall trends of the physical properties, only two main physical property units can be identified. Physical property Unit PP1 comprises the mound sedimentological facies (lithostratigraphic Unit 1$)$. It is characterized by cyclicity (10-11 cycles) in NGR and magnetic susceptibility, GRA density, and $P$-wave velocity. The low values of magnetic susceptibility indicate higher carbonate and lower siliciclastic contents. NGR parallels the magnetic susceptibility with values reflecting increased clay content. Floatstones containing higher clay content and a lower carbonate fraction generally correspond to peaks in the NGR and magnetic susceptibility. Density and $P$-wave velocity in these intervals are relatively high in comparison to the measurements at the other sites at these depths. The lower boundary of physical property Unit PP1, or mound base, is characterized by an increase in density, NGR, and magnetic susceptibility. The corresponding seismic facies is acoustically transparent, possibly due to the scattering effect of high coral content and the homogeneous seismic character of the sediments. The internal layers identified in the physical property measurements are probably not laterally consistent or do not cause a significant enough change in impedance to give internal reflectors inside the mound facies.

Physical property Unit PP2 is characterized by very low magnetic susceptibility values and eight peaks of high GRA density, $P$-wave velocity, density, and mag- netic susceptibility that coincide with more lithified layers and sandier layers. These layers are correlated with the high-amplitude sigmoid reflectors observed in the seismic profiles.

\section{Relationship between physical properties}

Statistical analysis and correlation tests have been performed on the different numerical data sets in order to evaluate the quality of the data, make direct comparisons between different laboratory equipment, and draw potential relationships among the physical property parameters within the described units. The statistical data analysis, including normality tests and confidence intervals for each individual core, assisted in the identification of outliers. Possible erroneous GRA-corrected density values from the uppermost $5 \mathrm{~cm}$ of a few cores were identified $(<1 \%)$ and checked against direct MAD bulk density measurements. These data were filtered out before further processing. A full set of correlation tables and associated graphs were utilized to aid in the identification of the most important physical parameters causing the seismic reflectors. Figure F29 shows a matrix plot of the correlation between the physical parameters in the cores. NGR (influenced by the clay content), density, porosity, shear strength, and magnetic susceptibility were compared with $P$-wave velocity.

Bulk density data, both from GRA and direct sample measurements (MAD), largely increase with depth throughout the mound and show a very good linear correlation ratio (Pearson's correlation coefficient $[\mathrm{PCC}]=0.75)$. Both density data sets also correlate well with the $P$-wave velocities measured on the split cores, except for the interval between 70 and 80 mbsf (Cores 307-U1317A-8H and 9H), where an increase in the sonic velocities, with a peak value of $1840 \mathrm{~m} / \mathrm{s}$ at $\sim 75 \mathrm{~m}$, is not reflected in the sediment density values, which remain rather constant or slightly decrease with considerable scatter. This increment in sound velocity is reflected in low shear strength values over the interval from 75 to $80 \mathrm{mbsf}$ and low porosity values for the whole interval.

There is a remarkably good correlation between NGR and shear strength throughout physical property Unit PP1 (PCC $=0.5$ ), especially in the uppermost 100 mbsf. In the interval between 86 and 92 mbsf, high NGR values, probably induced by an increase in clay content, are associated with peaks in shear strength values.

\section{Stratigraphic correlation}

The holes of Site U1317 were drilled along a depth transect from the upper mound flank to the top of 
the mound. No splicing was performed at this site to maintain the layer thickness of identified subunits in the mound along the transect that carry important information on mound development. Figure F30 illustrates the lateral continuity of the lithologic layers in the mound by correlation of the NGR records from each hole. This parameter best characterizes the stratigraphic cycles.

\section{Downhole measurements}

\section{Logging operation}

Following completion of RCB coring operations (bit size $=978$ inch) in Hole U1317D, the hole was conditioned with a wiper trip and was displaced with 84 bbl of 8.9 ppg sepiolite mud. The drill pipe was withdrawn to 77 mbsf in preparation for logging. All three scheduled tool strings were run: (1) the triple combo tool string, (2) the FMS-sonic tool string, and (3) the WST for a check shot survey (see "Downhole measurements" in the "Methods" chapter). A summary of the logging operation, including tools used, is provided in Figure F31 and Table T9. The heave conditions were good, typically $<2 \mathrm{~m}$ throughout the logging operation. All passes encountered an obstruction $19 \mathrm{~m}$ above the bottom of the hole at 251 mbsf (Fig. F31). The obstruction was probably material that fell from higher in the hole. Tool string rigup was begun on 6 May 2005 at $1200 \mathrm{~h}$ and the full operation completed by 7 May at $0230 \mathrm{~h}$.

The triple combo tool string was run first and was successfully lowered into the hole to 25 mbsf. In order to run the WST in accordance with the Marine Mammal Policy (i.e., during daytime and in the absence of marine mammals in the vicinity of the ship prior to and during the check shot survey), it was run before the FMS-sonic tool string. A total of 13 check shot stations were acquired at $\sim 15 \mathrm{~m}$ spacing, avoiding the washed-out section (Table T10). A first pass up to pipe depth (77 mbsf) was followed by a second pass up to seafloor after the pipe was raised by $7 \mathrm{~m}$. The Dipole Sonic Imager was run in $P$-wave and $S$-wave monopole and dipole shear modes and in first-motion detection mode. The $P$-wave velocity logs are of excellent quality. The FMS-sonic tool string was retrieved to the rig floor at $0230 \mathrm{~h}$ on 7 May.

\section{Data quality}

The triple combo tool string caliper indicated that the hole conditions were good except in a short section of the borehole (128-132 mbsf). Below $132 \mathrm{mbsf}$ and to $142 \mathrm{mbsf}$, the triple combo caliper indicated minor localized washouts confirmed by the calipers of the FMS-sonic tool string (Fig. F32A, F32C). The accelerometer data from the Temperature/Acceleration/Pressure (TAP) tool indicate that stick-slip of the triple combo tool string remained at low levels through the entire open interval (Fig. F32B). Similar to the triple combo tool string, vertical acceleration $\left(\mathrm{A}_{\mathrm{z}}\right)$ of the FMS-sonic tool string remained at levels characteristic of normal stick-slip motion (Fig. F32D). The orientation of the reference pad of the FMS (Fig. F32G, F32H) shows an absence of rotation due to the elliptical shape of the hole (major axis oriented along $30^{\circ}$ ). As a result, the two passes followed exactly the same path (Fig. F32I) and consequently do not improve the FMS coverage of the borehole wall. The FMS images are generally of good quality except (1) within the cave initially detected by the caliper of the triple combo tool string, (2) in the lower part of the logged section where spurious features were interpreted as drilling marks, and (3) images from two of the FMS pads that were worn and produced images that were less clear than those produced by the other two pads.

The level of NGR in the penetrated formation is low and the signal is attenuated through the pipe. The step in gamma radiation at the sediment/water interface was observed at 816 mbrf. The seafloor depth differs by $<2.0 \mathrm{~m}$ from the seafloor depth determined by the driller. Using this reference scale, the pipe depth was placed at 77 mbsf. Data from the triple combo tool string served as reference by which the features in the equivalent logs of subsequent FMSsonic tool string runs were matched (Fig. F33B, F33C).

\section{Logging stratigraphy}

Two main logging units are characterized based on (1) the impulsive characters of the resistivity (Fig. F34C), bulk density (Fig. F34D), and acoustic velocity $\left(V_{\mathrm{p}}\right)$ (Fig. F34F) logs in the bottom part of the open hole and (2) major changes in the cyclicity of the porosity log (Fig. F34D).

The first logging unit has been further divided into two subunits based on a clear shift in gamma radiation (Fig. F34A).

\section{Logging Subunit 1a: Base of pipe (77 mbsf)-106 mbsf}

Logging Subunit $1 \mathrm{a}$ is characterized by a progressive enrichment in Th (from 2 to $6 \mathrm{ppm}$ ) and an increase in density (from 1.55 to $2.0 \mathrm{~g} / \mathrm{cm}^{3}$ ) with depth. The acoustic velocity is constant with an average value of $\sim 1700 \mathrm{~m} / \mathrm{s}$. Resistivity values are low $(\sim 1 \Omega \cdot \mathrm{m})$ (Fig. F34C). Logging Subunit 1a correlates with lithostratigraphic Unit 1, the Pleistocene coral mound succession (see "Lithostratigraphy"). 


\section{Logging Subunit 1b: 106-141 mbsf}

Overall, this subunit is characterized by cyclic fluctuations of intermediate frequency in the gamma radiation, K, porosity, bulk density, and acoustic velocity logs. The lower boundary of logging Subunit $1 \mathrm{~b}$ is defined by the minimal value in the gamma ray and porosity logs and a step in the resistivity, density, and sonic velocity $\left(V_{\mathrm{p}}\right)$ logs. The acoustic velocity increases slightly over the unit up to $2000 \mathrm{~m} / \mathrm{s}$.

\section{Logging Unit 2: 141-bottom of the logged section (251 mbsf)}

Logging Unit 2 is characterized by localized spikes in the resistivity and acoustic $\left(V_{\mathrm{p}}\right)$ logs. These spikes parallel the photoelectric effect factor log and suggest a cementation/lithification of carbonate-rich layers. This interpretation is consistent with the corresponding decrease of gamma radiation attributed to a decrease in clay content. Logging Unit 2 correlates with the bottom part of lithostratigraphic Unit 2 Miocene drift sediments (see "Lithostratigraphy").

\section{Discussion}

\section{Core-log integration}

Total gamma ray counts and densities have the potential to be correlated to downhole logging data and finally presented in the equivalent logging depth scale (Fig. F35).

\section{Check shot survey and core-log-seismic integration}

The one-way sonic traveltimes from the ship to the WST downhole were deduced from the first arrival in the recorded waveform. Interval velocities were calculated from the one-way traveltimes (Fig. F34F). These measurements provide an independent way to validate the correlation of the borehole to the seismic sections in addition to the synthetic seismogram. Using the excellent-quality density and acoustic logs (Fig. F34E, F34F), a synthetic seismogram will be constructed postcruise and will provide a means of matching the reflections expected from the formation (based on measured physical properties from logging and core sources) with those in the seismic data.

\section{Thermal measurements}

Three independent sets of thermal measurements were collected at this site (Fig. F36). The first data set contains three in situ measurements of formation temperature measured by the APCT during drilling operations in Hole U1317A. During the logging operation, the temperature of the borehole fluid was measured by the Schlumberger Environmental Measurement Sonde and Lamont-Doherty Earth Observatory Borehole Research Group TAP tool. Despite the constant shift of $2^{\circ} \mathrm{C}$ between these two temperature logs, the temperature measurements show a linear increase with depth. No significant fluid flow that could be implied by changes in the gradient of the temperature was detected. Thermal conductivity measured on cores has values that are between 0.8 and $1.8 \mathrm{~W} / \mathrm{m} \cdot \mathrm{K}$ and are relatively constant in the 65125 mbsf interval. An overall decrease of thermal conductivity with depth is observed.

\section{Microresistivity FMS images}

Of all our downhole logs, only the microresistivity (FMS; sampling rate $=0.1$ inch) images can resolve high-frequency cycles and the thin lithified carbonate-rich layers in detail. Figure F37 allows comparisons between the texture of the two distinct logging units. Manual picking of sinusoidal features on the FMS images allows us to identify and characterize the strike and dip of the bedding or factures. Although the FMS images in the bottom portion of the hole may have been impaired by drilling disturbance, if bedding orientation is confirmed by postcruise analyses, these images may be of great value to establish the structural context of the base of the mound.

\section{References}

Berggren, W.A., Hilgen, F.J., Langereis, C.G., Kent, D.V., Obradovich, J.D., Raffi, I., Raymo, M.E., and Shackleton, N.J., 1995a. Late Neogene chronology: new perspectives in high-resolution stratigraphy. Geol. Soc. Am. Bull., 107:1272-1287. doi:10.1130/0016-

7606(1995)107<1272:LNCNPI>2.3.CO;2

Berggren, W.A., Kent, D.V., Swisher, C.C., III, and Aubry, M.-P., 1995b. A revised Cenozoic geochronology and chronostratigraphy. In Berggren, W.A., Kent, D.V., Aubry, M.-P., and Hardenbol, J. (Eds.), Geochronology, Time Scales and Global Stratigraphic Correlation. Spec. Publ.-SEPM (Soc. Sediment. Geol.), 54:129-212.

Beyer, A., Schenke, H.W., Klenke, M., and Niederjasper, F., 2003. High resolution bathymetry of the eastern slope of the Porcupine Seabight. Mar. Geol., 198:27-54. doi:10.1016/S0025-3227(03)00093-8

De Mol, B., Henriet, J.-P., and Canals, M., 2005. Development of coral banks in Porcupine Seabight: do they have Mediterannean ancestors? In Freiwald, A., and Roberts, J.M. (Eds.), Cold-Water Corals and Ecosystems: Heidelberg (Springer-Verlag), 513-533.

De Mol, B., Van Rensbergen, P., Pillen, S., Van Herreweghe, K., Van Rooij, D., McDonnell, A., Huvenne, V., Ivanov, M., Swennen, R., and Henriet, J.-P., 2002. Large deepwater coral banks in the Porcupine Basin, southwest of 
Ireland. Mar. Geol., 188(1-2):193-231. doi:10.1016/ S0025-3227(02)00281-5

Foubert, A., Beck, T., Wheeler, A.J., Opderbecke, J., Grehan, A., Klages, M., Thiede, J., Henriet, J.-P., and the Polarstern ARK-XIX/3A Shipboard Party, 2005. New view of the Belgica mounds, Porcupine Seabight, NE Atlantic: preliminary results from the Polarstern ARKXIX/3a ROV cruise. In Freiwald, A., and Roberts, J.M. (Eds.), Cold-Water Corals and Ecosystems: Heidelberg (Springer-Verlag), 403-415.

Henriet, J.-P., Guidard, S., and the ODP Proposal 573 Team, 2002. Carbonate mounds as a possible example for microbial activity in geological processes. In Wefer, G., Billet, D., Hebbeln, D., Jørgensen, B.B., Schlüter, M., and Van Weering, T.C.E. (Eds.), Ocean Margin Systems: Heidelberg (Springer-Verlag), 439-455.

Jenkins, D.G., 1985. Southern mid-latitude Paleocene to Holocene planktonic foraminifera. In Bolli, H.M., Saunders, J.B., and Perch-Nielsen, K. (Eds.), Plankton Stratigraphy: Cambridge (Cambridge Univ. Press), 263-282.

Jenkins, D.G., 1993. Cenozoic southern mid- and high-latitude biostratigraphy and chronostratigraphy based on planktonic foraminifera. In Kennett, J.P., and Warnke, D.A. (Eds.), The Antarctic Paleoenvironment: A Perspective on Global Change. Antarct. Res. Ser., 60:125-144.
Naeth, J., di Primio, R., Horsfield, B., Schaefer, R.G., Shannon, P.M., Bailey, W.R., and Henriet, J.-P., 2005. Hydrocarbon seepage and carbonate mound formation: a basin modeling study from the Porcupine Basin (offshore Ireland). J. Pet. Geol., 28:147-166.

Parkes, R.J., Cragg, B.A., and Wellsbury, P., 2000. Recent studies on bacterial populations and processes in marine sediments: a review. Hydrogeol. Rev., 8:11-28.

Rice, A.L., Billet, D.S.M., Thurston, M.H., and Lampitt, R.S., 1991. The Institute of Oceanographic Sciences Biology programme in the Porcupine Seabight: background and general introduction. J. Mar. Biol. Assoc. U. K., 71:281-310.

Van Rooij, D., De Mol, B., Huvenne, V., Ivanov, M., and Henriet, J.-P., 2003. Seismic evidence of current-controlled sedimentation in the Belgica mound province, upper Porcupine slope, SW of Ireland. Mar. Geol., 195(14):31-53. doi:10.1016/S0025-3227(02)00681-3

White, M., 2001. Hydrography and Physical Dynamics at the NE Atlantic Margin that Influence the Deep-Water Cold Coral Reef Ecosystem-EU ACES-ECOMOUND Internal Report: Galway, Ireland (Dept. Oceanogr., NUI).

Publication: 14 October 2006

MS 307-104 
Figure F1. Location of Site U1317 Holes U1317A-U1317E on Challenger Mound (multibeam bathymetry; Beyer et al., 2003).

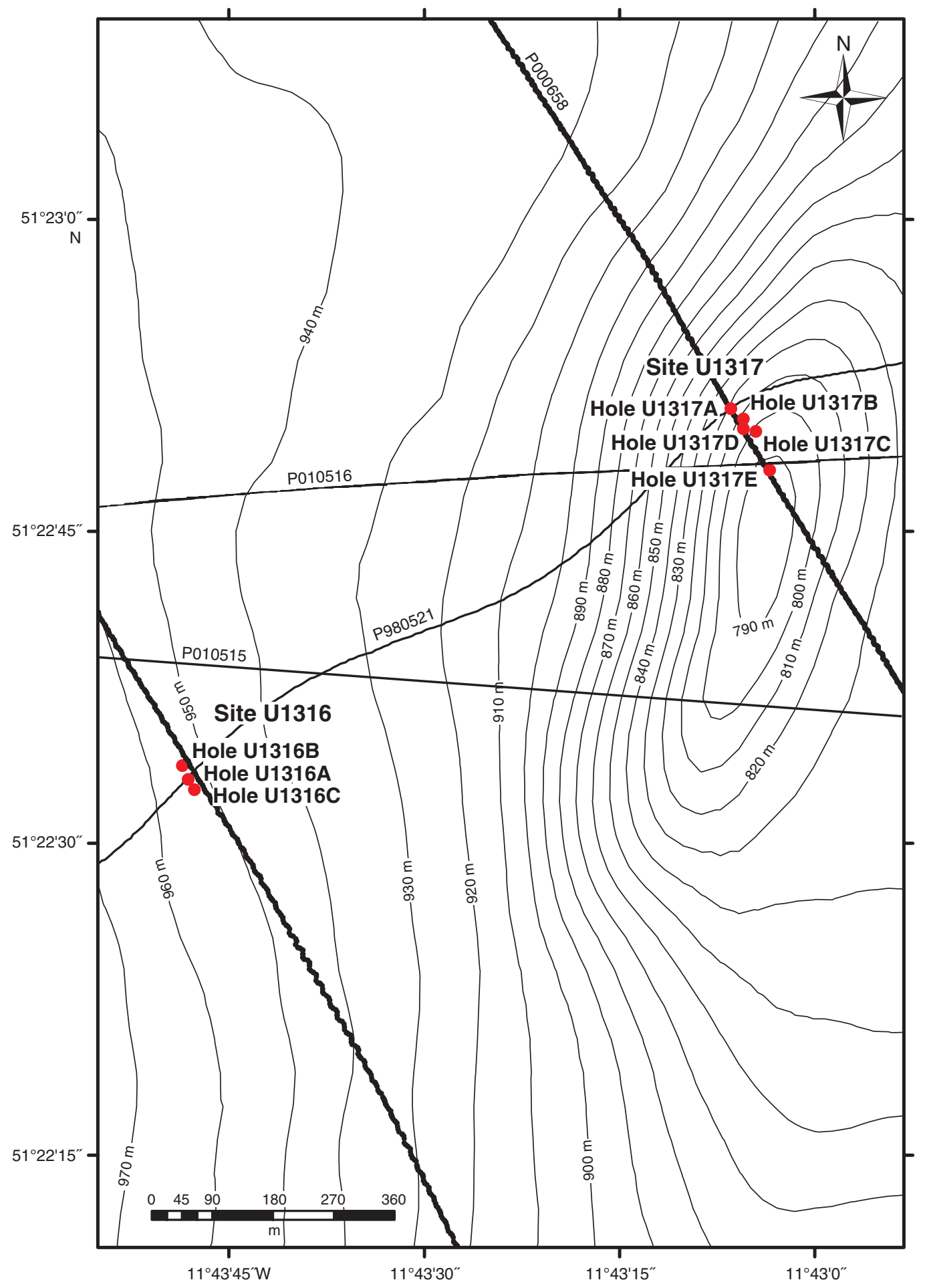


Figure F2. Downslope seismic section of Challenger Mound and Site U1317.

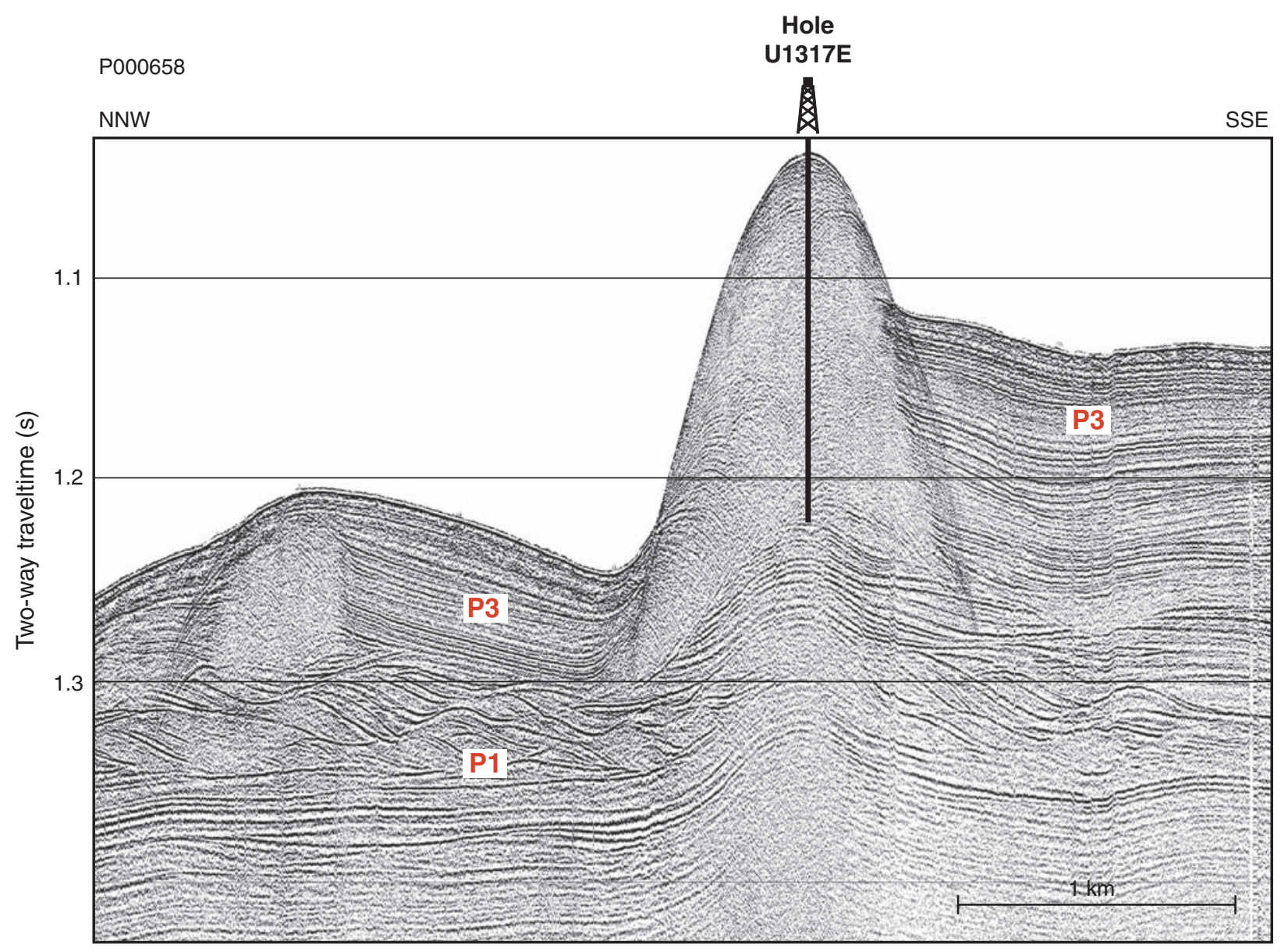


Figure F3. Sedimentological log of the Pleistocene mound succession (lithostratigraphic Unit 1) in Hole U1317A. In this hole, the mound base is identified at $130.1 \mathrm{mbsf}$.

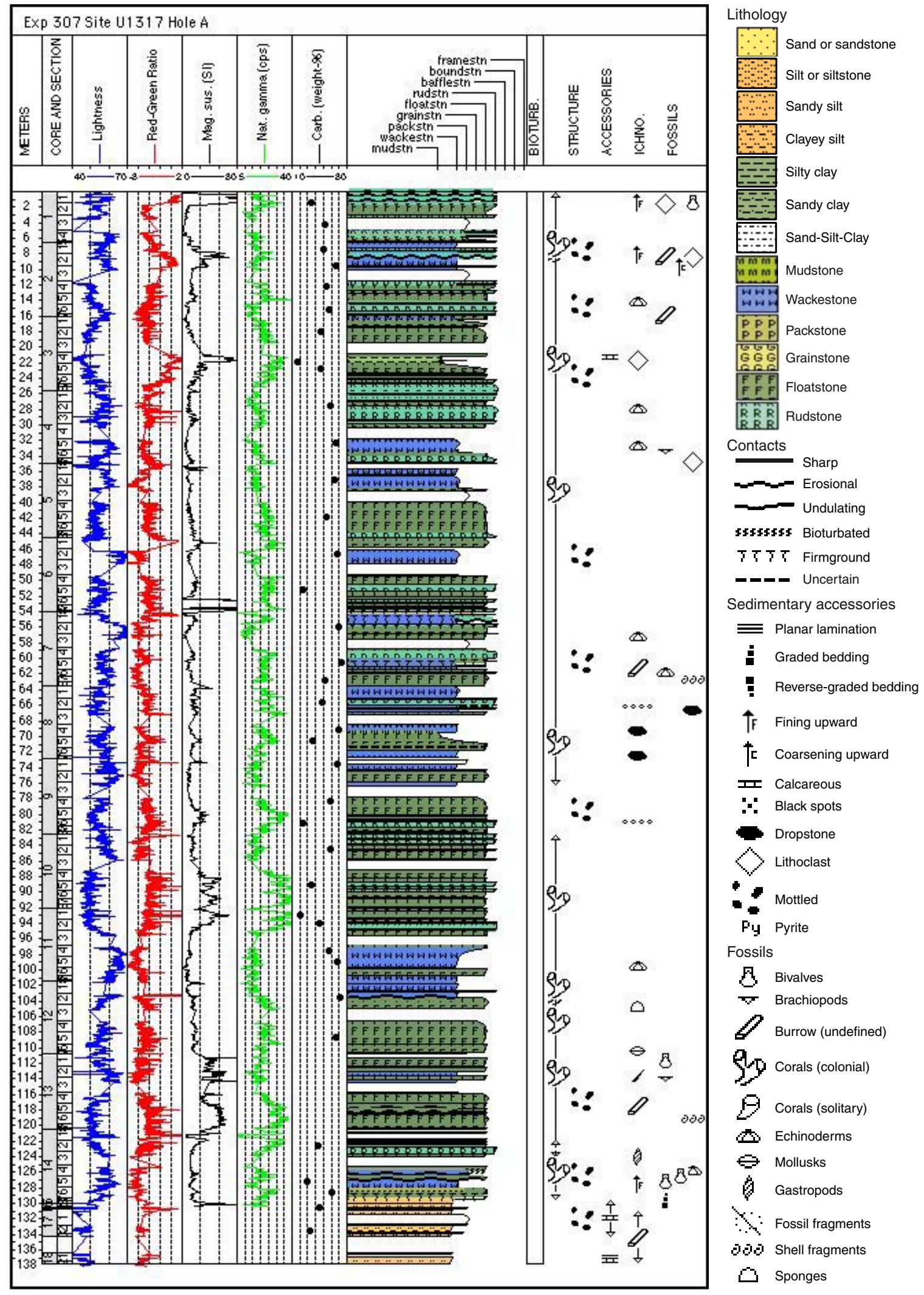


Figure F4. Sedimentological log of the Miocene drift successions (lithostratigraphic Unit 2) in Hole U1317D. The boundary between the siltstone facies and the sandstone facies is at 197 mbsf. See Figure F3 for symbol legend.

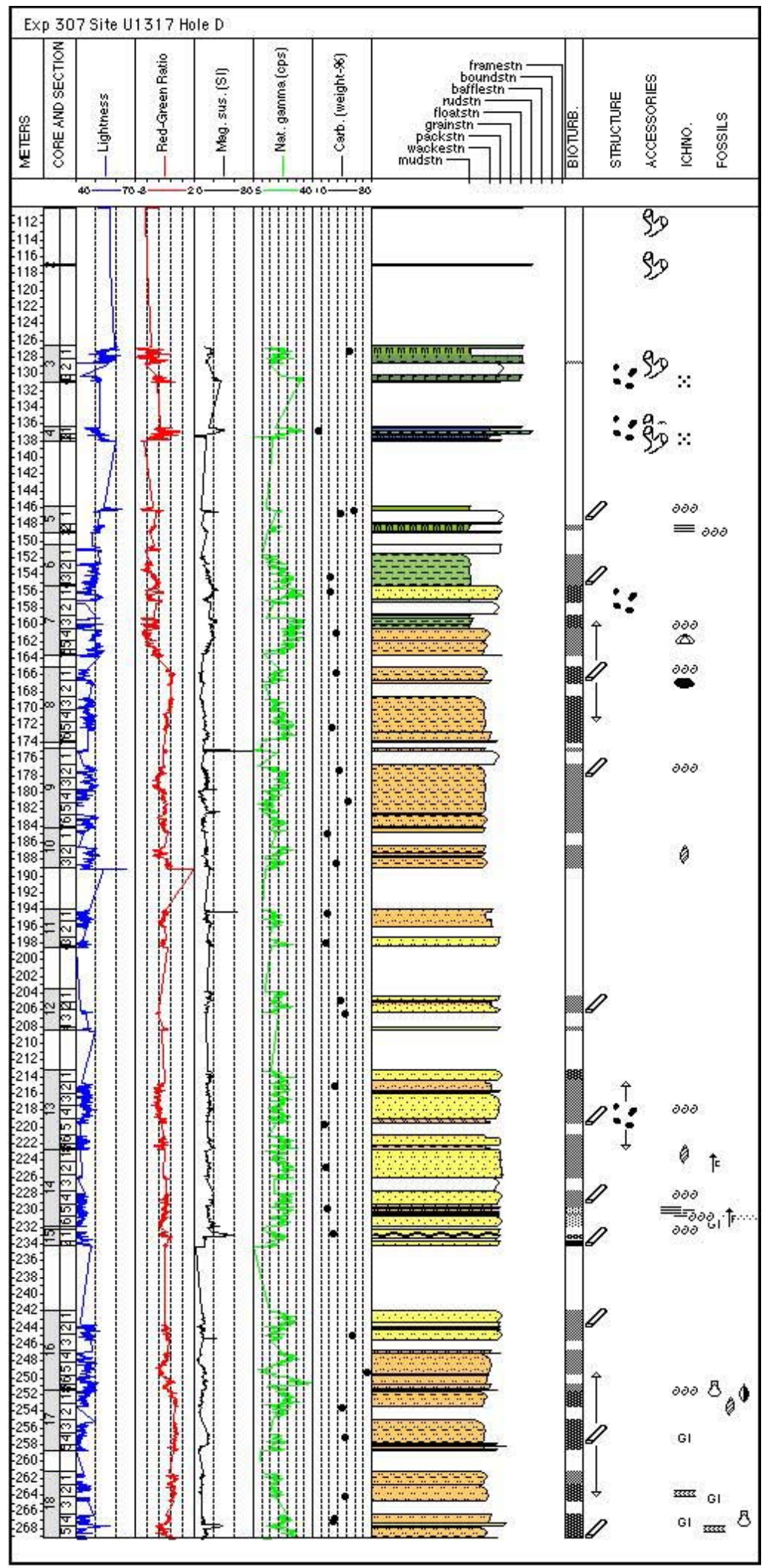


Figure F5. Simplified logs of Holes U1317B, U1317C, and U1317E. Lithified intervals are indicated by blue lines. Note that the thickness of the mound section (lithostratigraphic Unit 2) increases toward the mound summit.

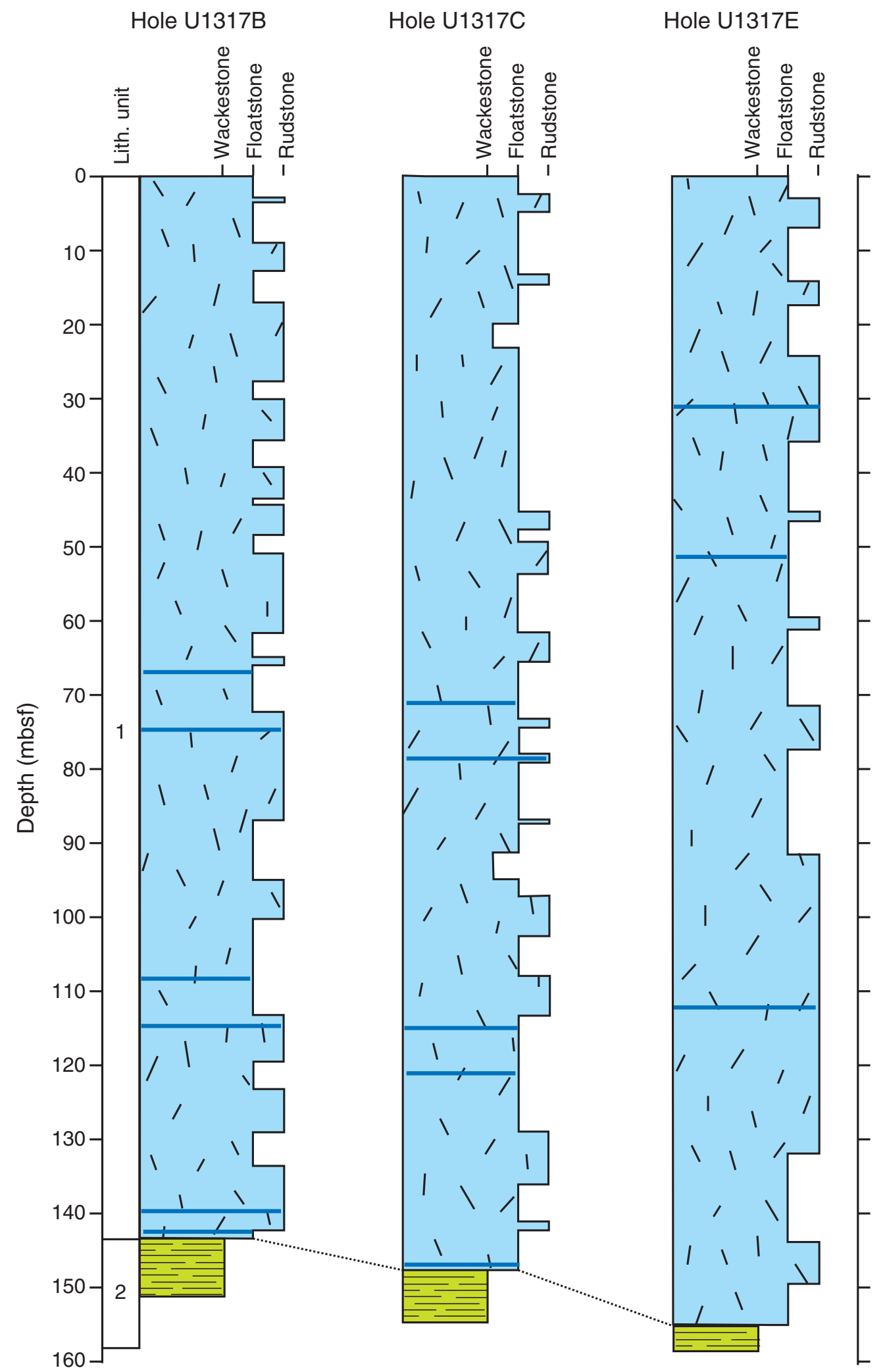


Figure F6. A. Coral floatstone with greenish gray wackestone matrix (interval 307-U1317C-4H-7, 65-77 cm). B. Coral rudstone overlying coral floatstone (interval 307-U1317C-4H-7, 77-89 cm). C. Light bluish gray wackestone, nodular partly lithified with poorly preserved corals (interval 307-U1317A-9H-2, 92-104 cm). D. Firmground of light gray wackestone overlain by gray packstone. Burrows within the firmground are filled with overlying packstone sediments (interval 307-U1317A-7H-1, 117-129 cm).

$\mathbf{A}_{\mathrm{cm}}$

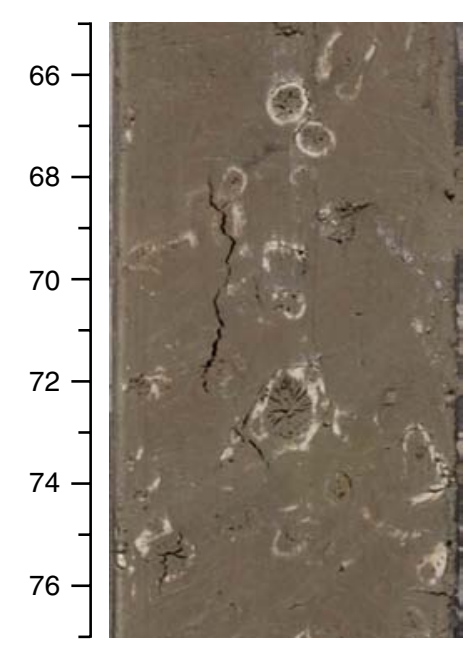

$\mathbf{C}_{\mathrm{cm}}$

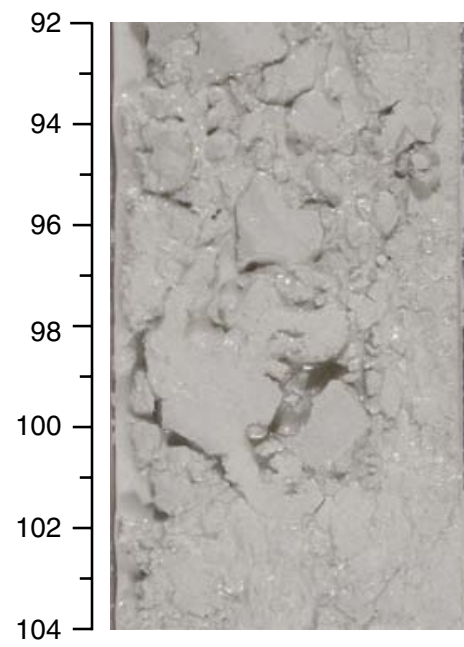

$\mathbf{B}_{\mathrm{cm}}$

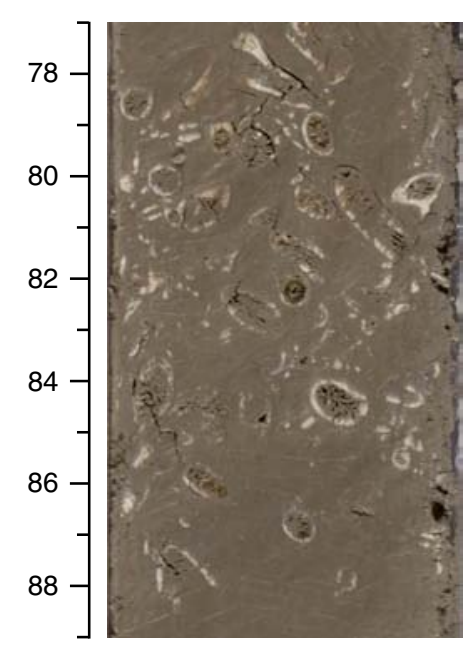

$\mathbf{D}_{\mathrm{cm}}$

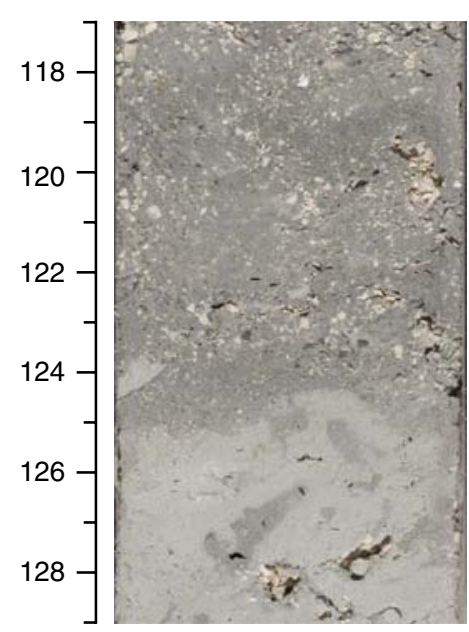


Figure F7. A. Coral floatstone abruptly changing into calcareous sandy clay including a large dropstone (interval 307-U1317C-2H-3, 68-80 cm). B. Boundary between the Pleistocene mound succession (lithostratigraphic Unit 1) and the Pliocene and Miocene drift succession of lithostratigraphic Unit 2 (interval 307-U1317A-7H-1, 3-15 cm). C. Erosional boundary within Miocene drift succession (interval 307-U1317D-15R-1, 54-66 cm). D. Silty fine sand of the Miocene drift succession with burrow (interval 307-U1317D-12R-2, 7-19 cm).

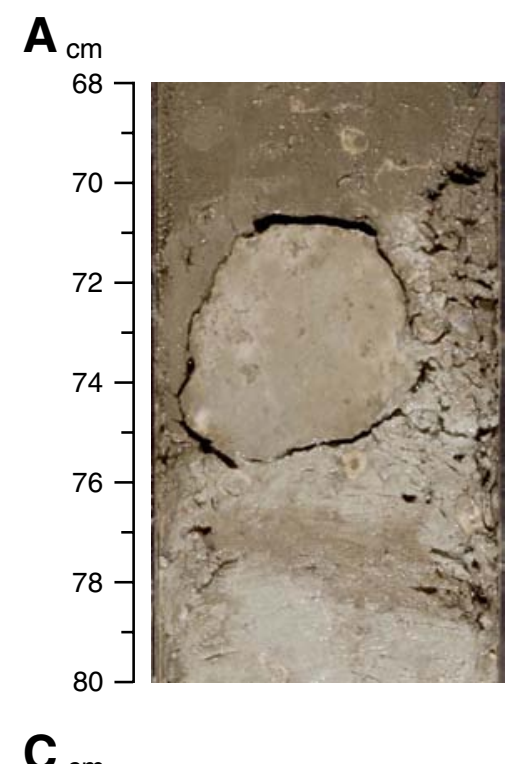

$\mathbf{B}_{\mathrm{cm}}$
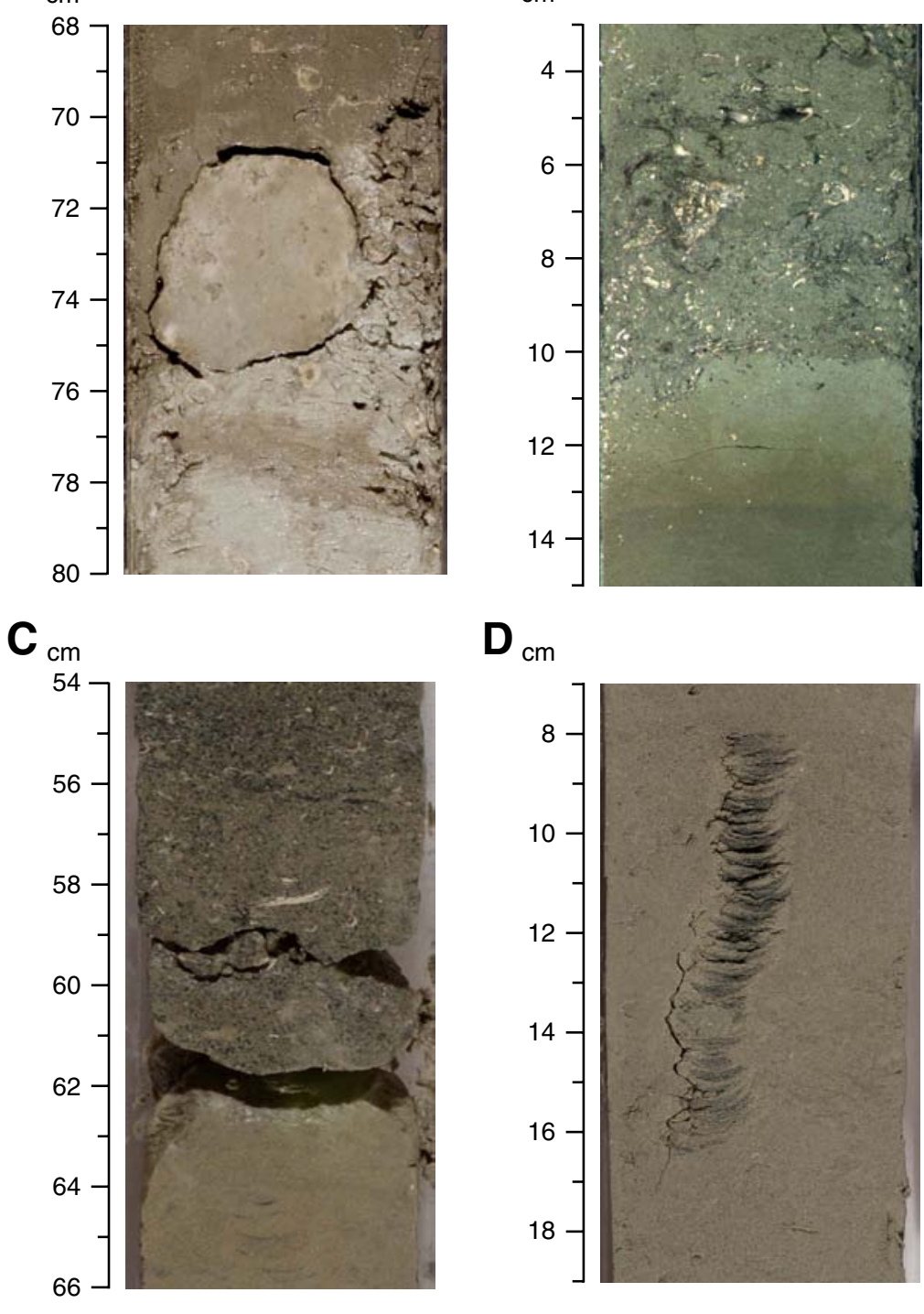

$\mathbf{D}_{\mathrm{cm}}$

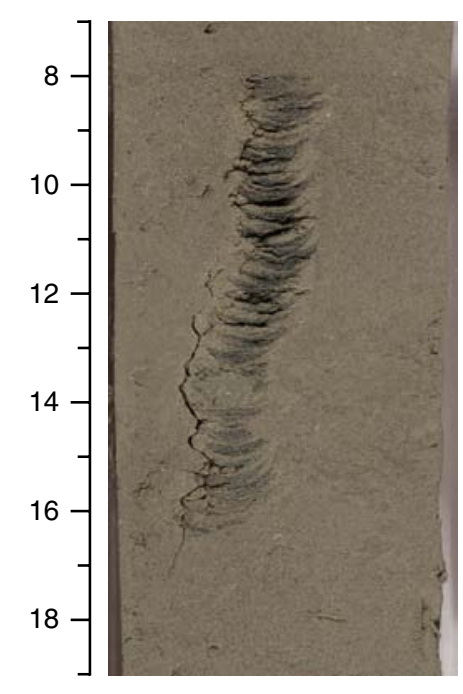


Figure F8. Stratigraphic position of calcareous nannofossil and planktonic foraminifer zones at Site U1317. Wavy lines = hiatus, dashed boundaries = uncertainty.

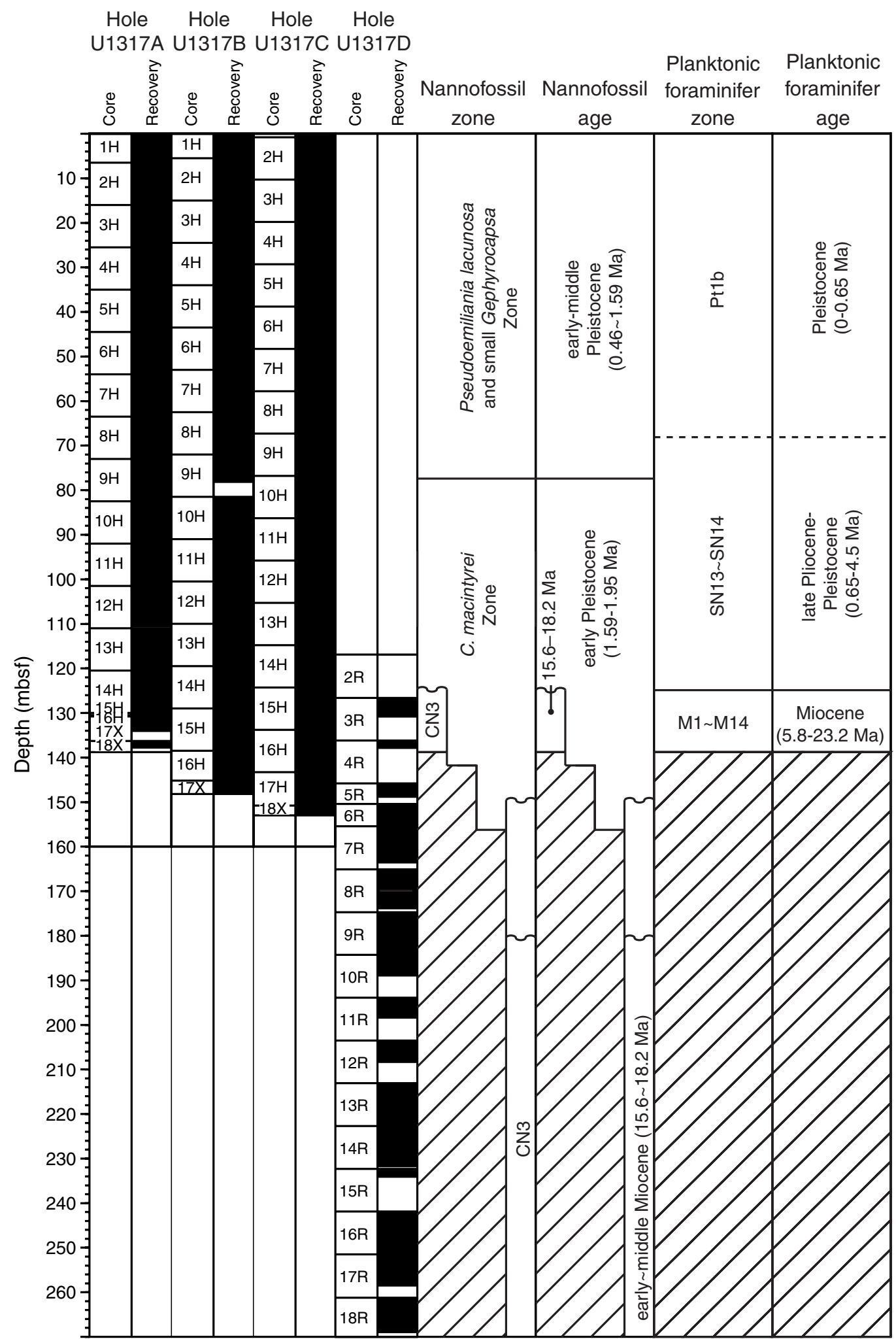


Figure F9. Range chart of age-diagnostic calcareous nannofossil taxa in Hole U1317A. Upward flags = FAD, downward flags $=$ LAD.

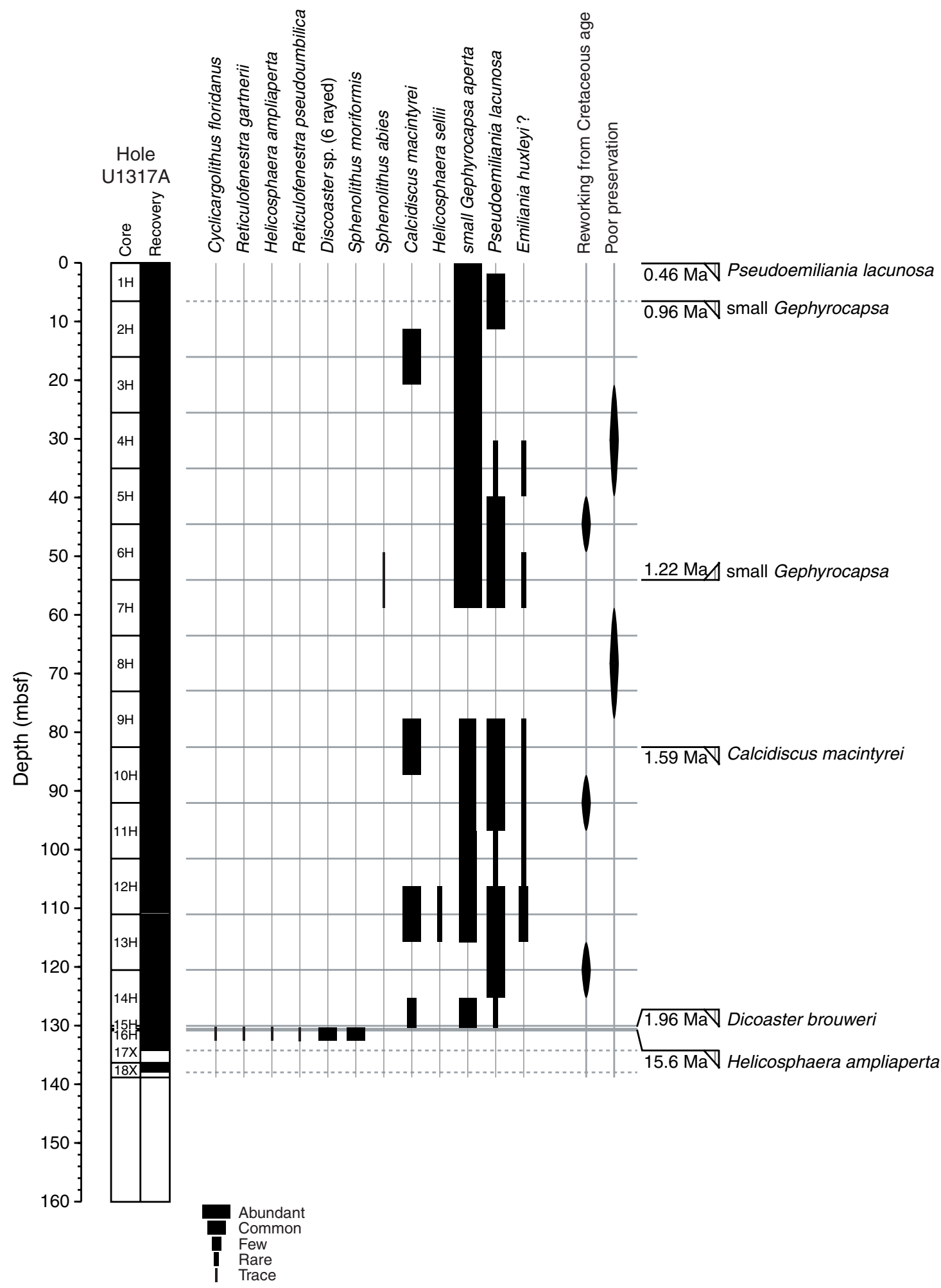


Figure F10. Planktonic foraminifer biostratigraphy in Hole U1317A. Age of lithostratigraphic Unit 1 ranges from Pliocene to Pleistocene, and Unit 2 is Miocene. Upward flags = FAD, downward flags = LAD.

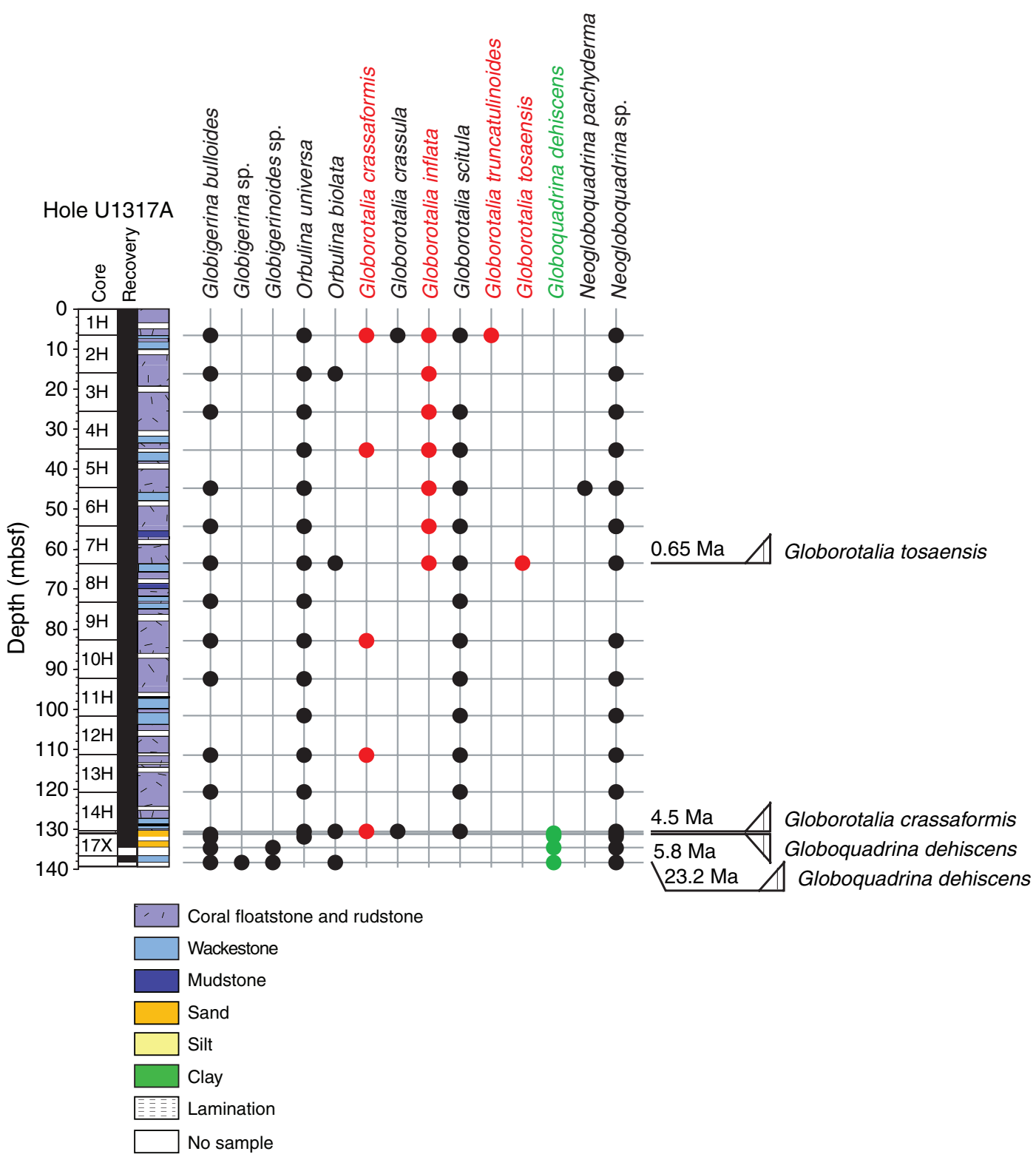


Figure F11. Occurrences of benthic foraminifers from the core catcher of each core in Hole U1317A.

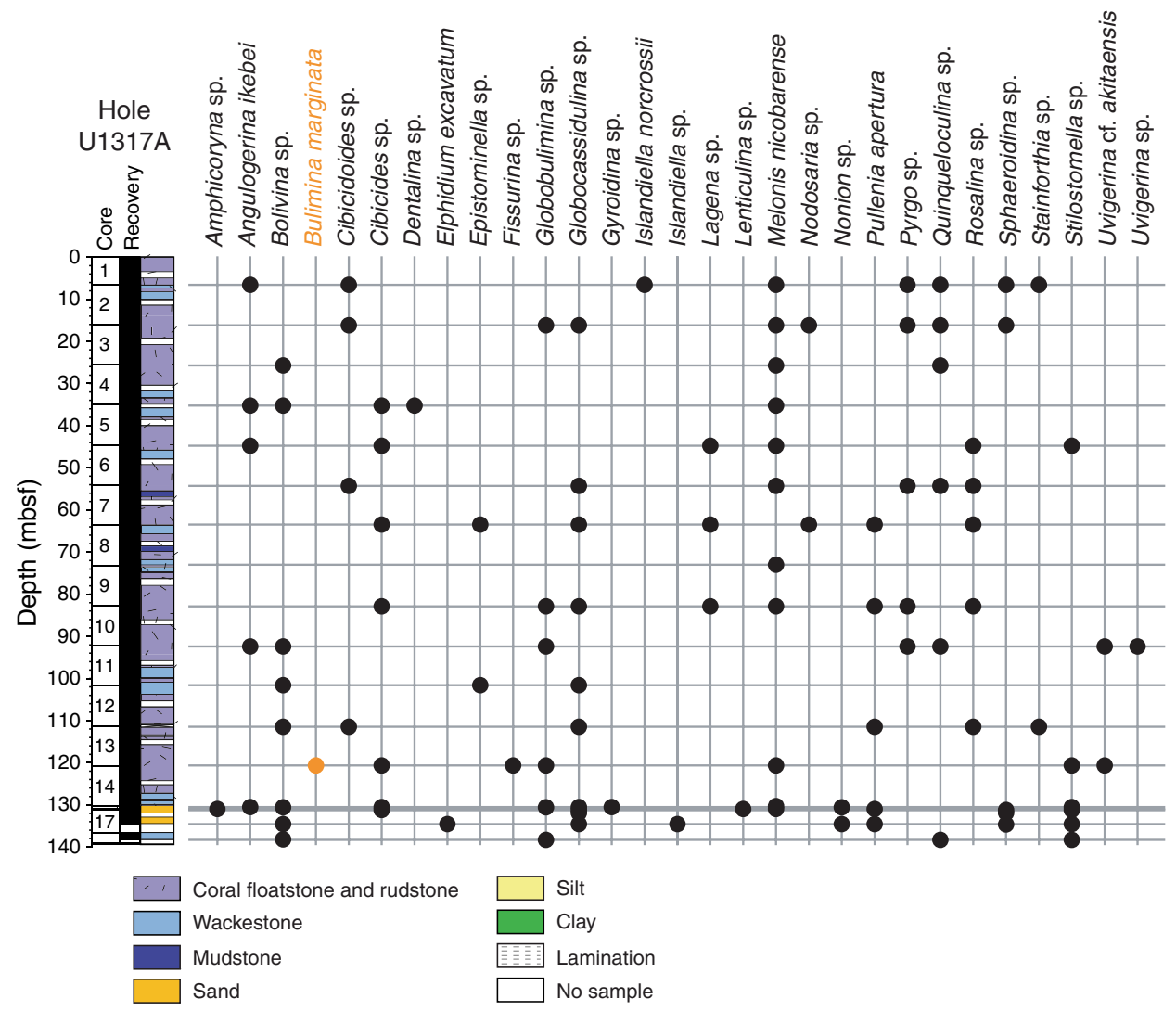


Figure F12. Stepwise AF demagnetization $(5,10,15$, and $20 \mathrm{mT}$ ) of Section 307-U1317A-1H-1 at (A) 0.40 mbsf and (B) 1.20 mbsf. Left panels represent orthogonal projection of endpoints of the magnetization vector. Open symbols $=$ projection on vertical plane, solid symbols $=$ projection on horizontal plane. Middle panels represent change in magnetization intensity during AF demagnetization. Right panels represent equal area projection of the magnetization vector during demagnetization.

A

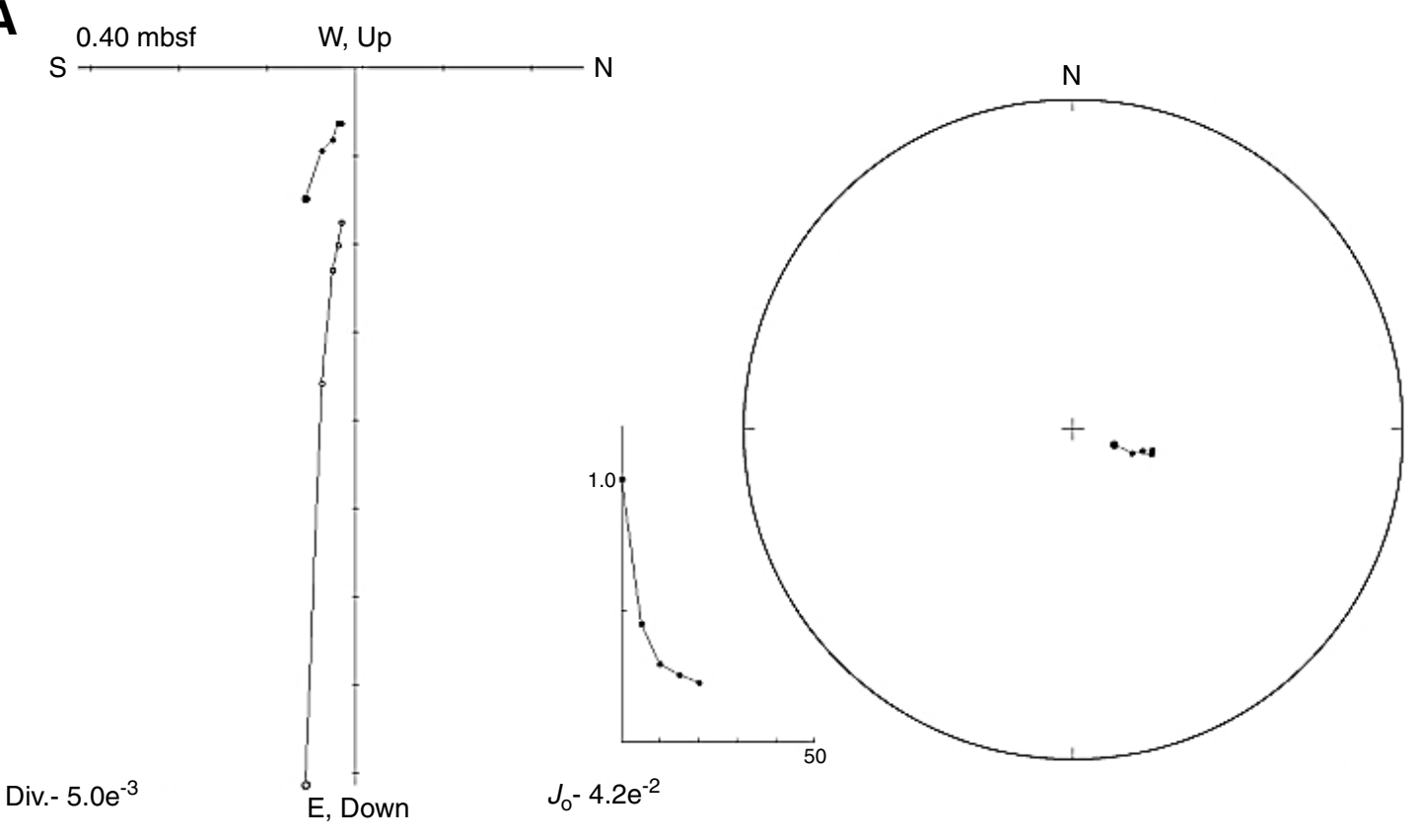

B

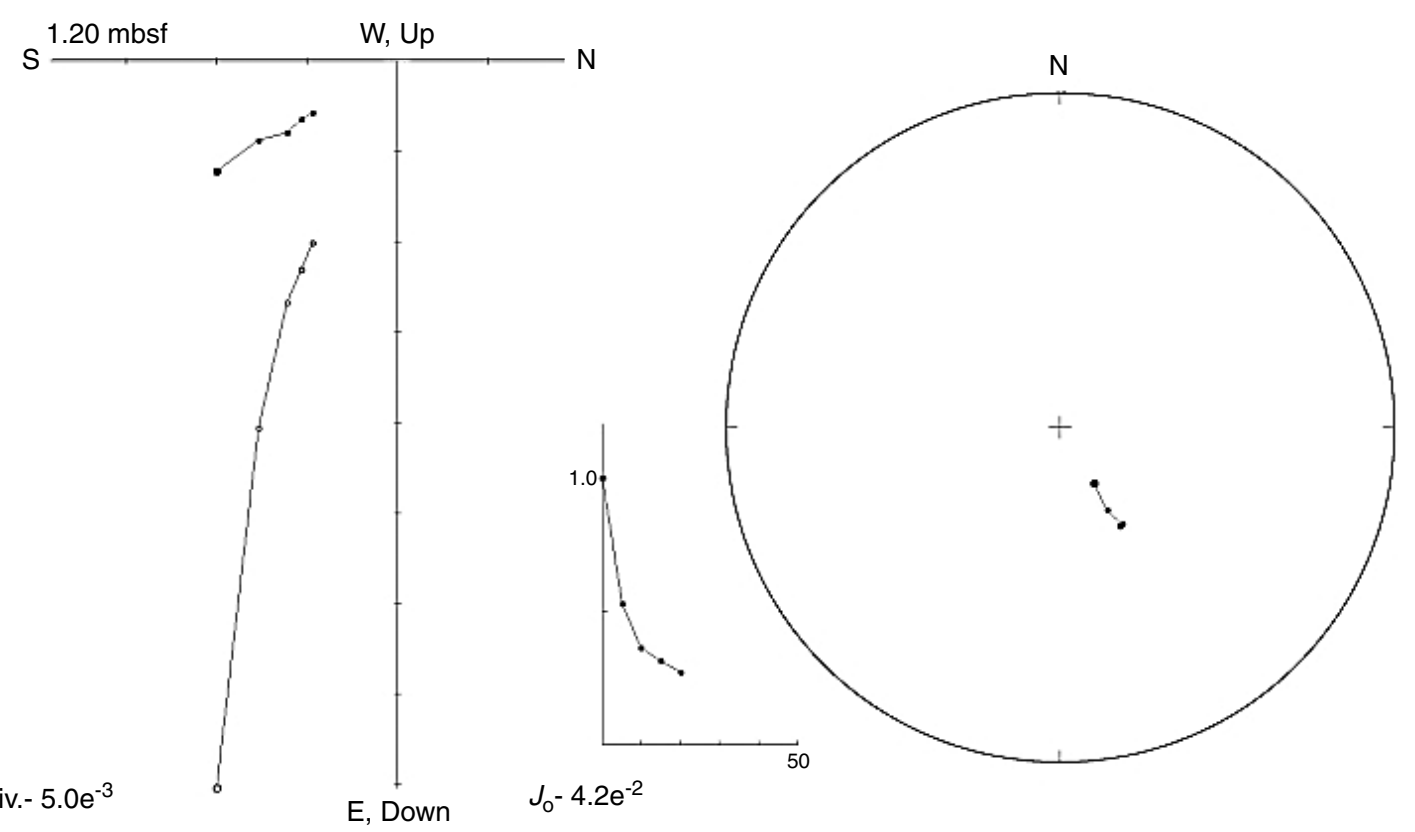


Figure F13. Inclination of magnetization vector vs. depth in Holes U1317A, U1317B, U1317C, and U1317E after AF demagnetization at peak fields of $15 \mathrm{mT}$ and two magnetostratigraphic interpretations.

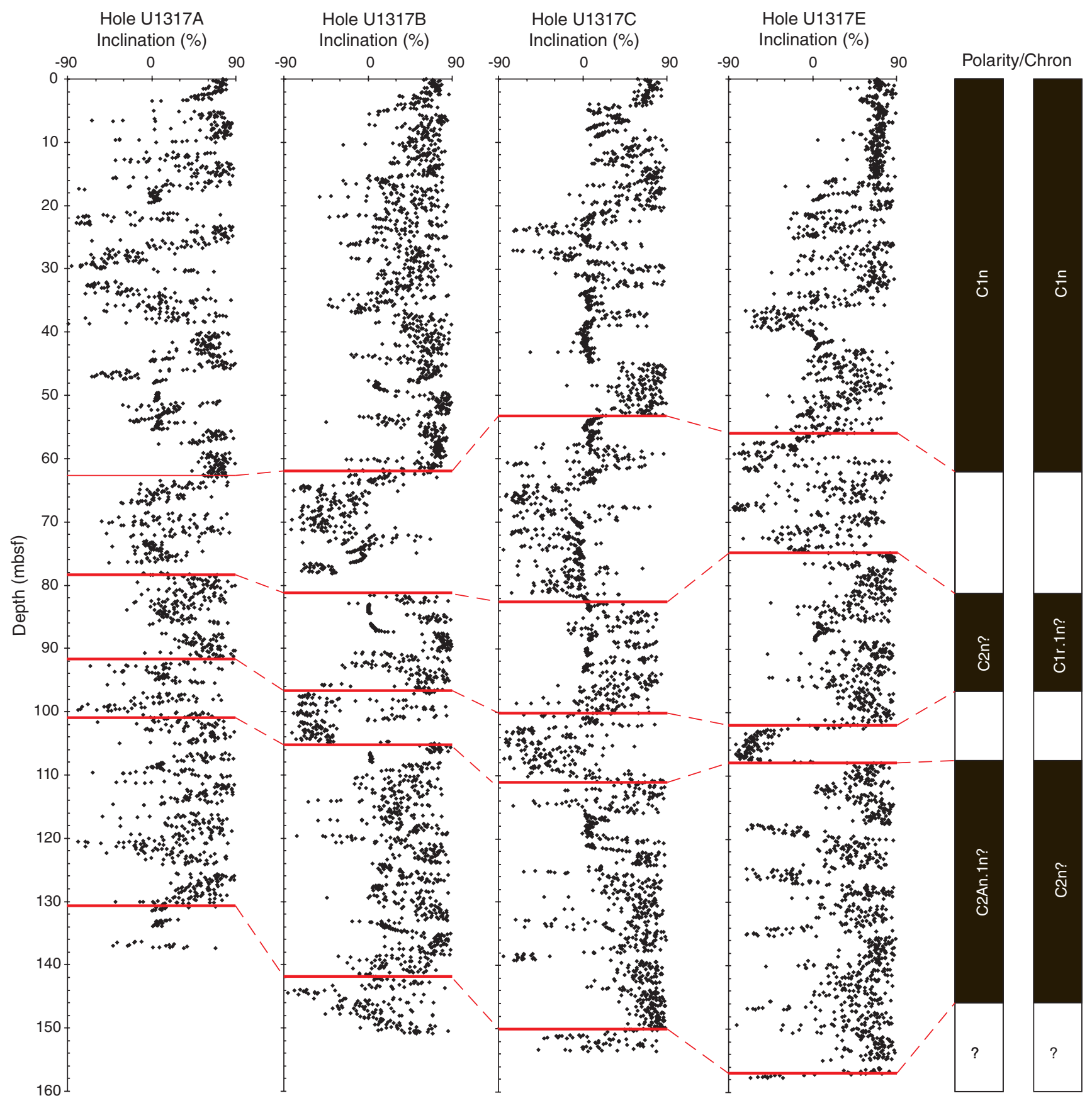


Figure F14. Inclination of the magnetization vector and magnetization intensity vs. depth in Hole U1317D after AF demagnetization at peak fields of $15 \mathrm{mT}$.

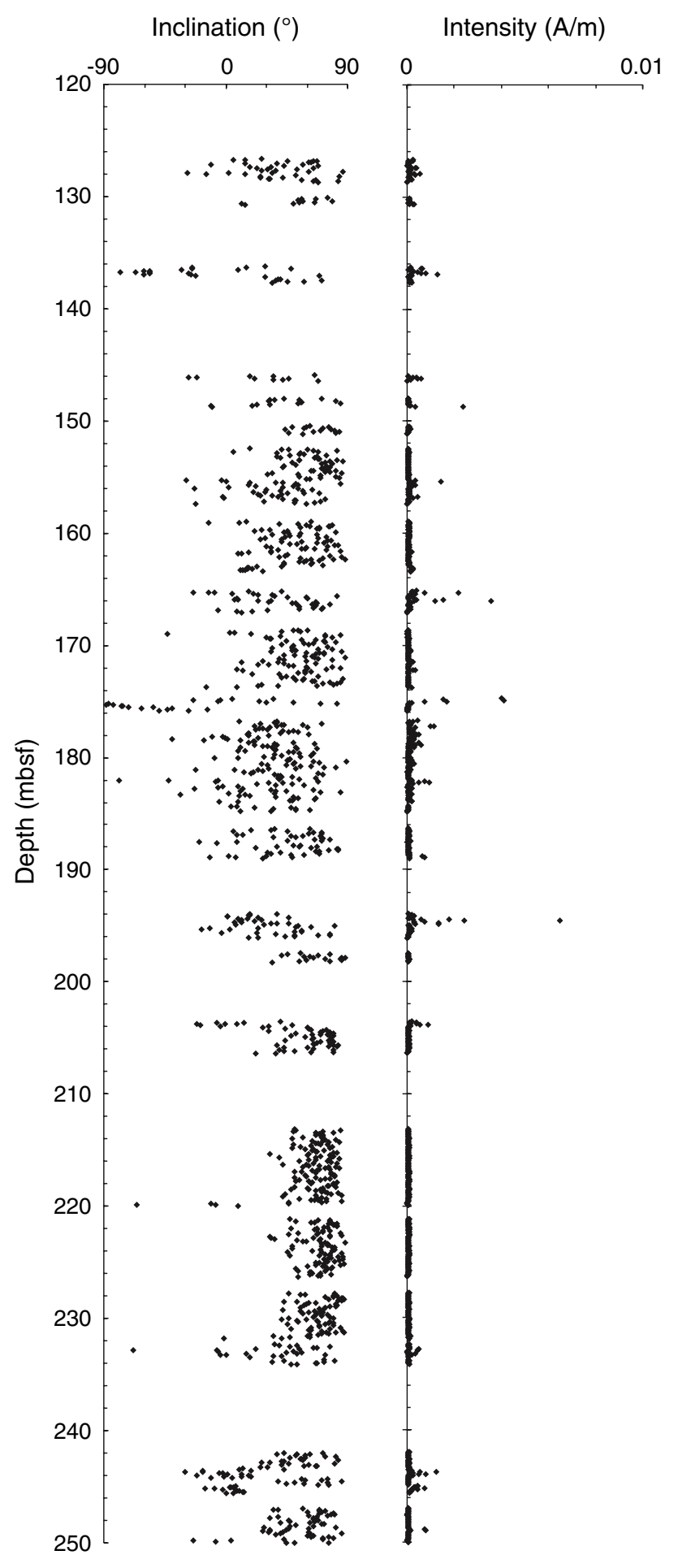


Figure F15. Magnetization intensity divided by the magnetic susceptibility (MS) vs. depth after AF demagnetization at peak fields of $15 \mathrm{mT}$.

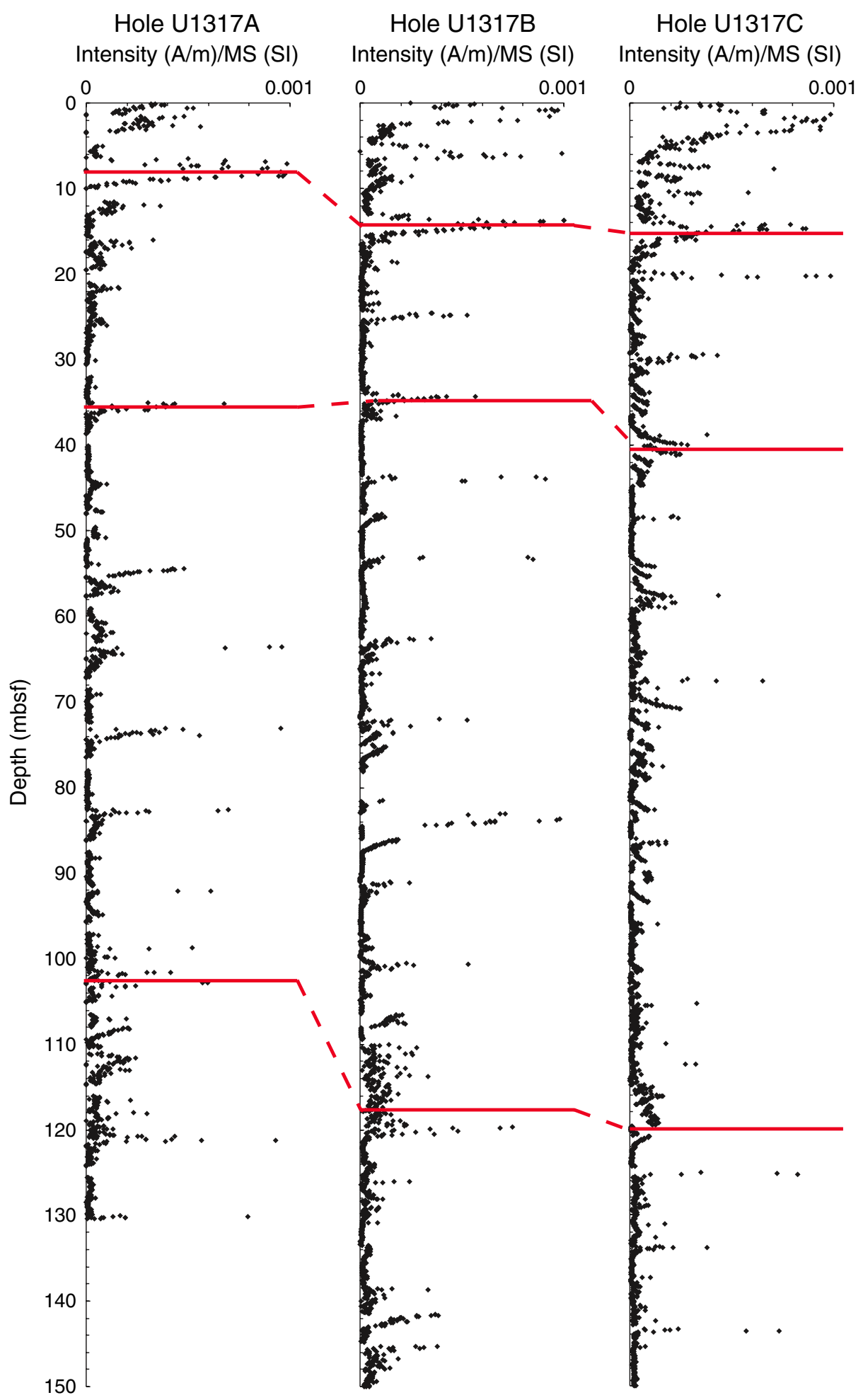


Figure F16. Concentrations of the dissolved chemical species vs. depth. A. Strontium. B. Lithium. C. Boron. D. Chlorinity (by titration). E. pH. Solid circles $=$ Hole U1317A, open diamonds $=$ Hole U1317D, open squares $=$ Hole U1317E.
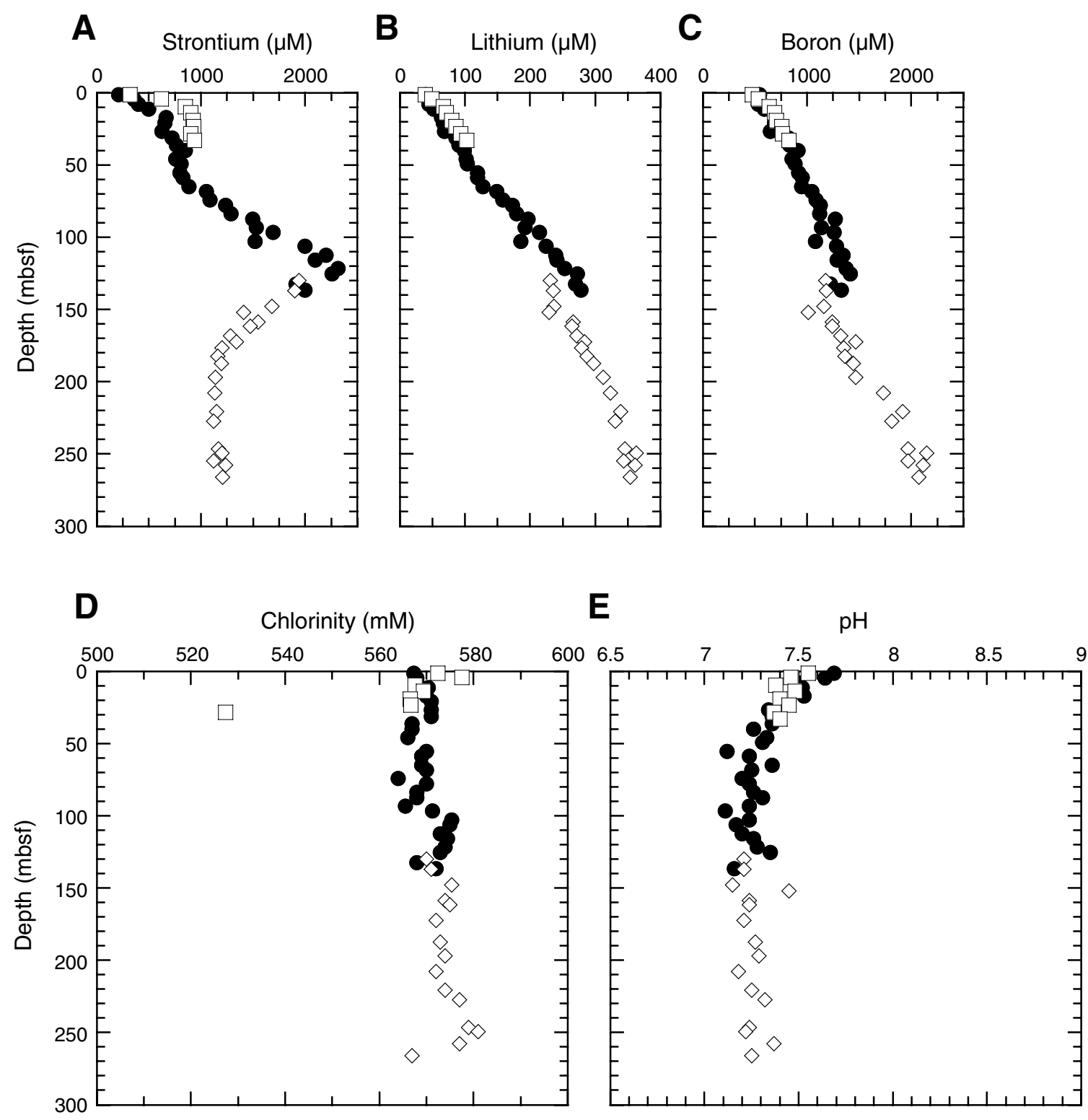
Figure F17. Concentrations of dissolved chemical species and adsorbed gas vs. depth. A. Dissolved inorganic carbon (DIC). B. Alkalinity C. Sulfate. D. Calcium. E. Magnesium. F. Dissolved methane. G. Adsorbed methane. H. Dissolved ethane. I. Ammonium. J. Barium. Solid circles $=$ Hole U1317A, open diamonds = Hole U1317D, open squares $=$ U1317E.
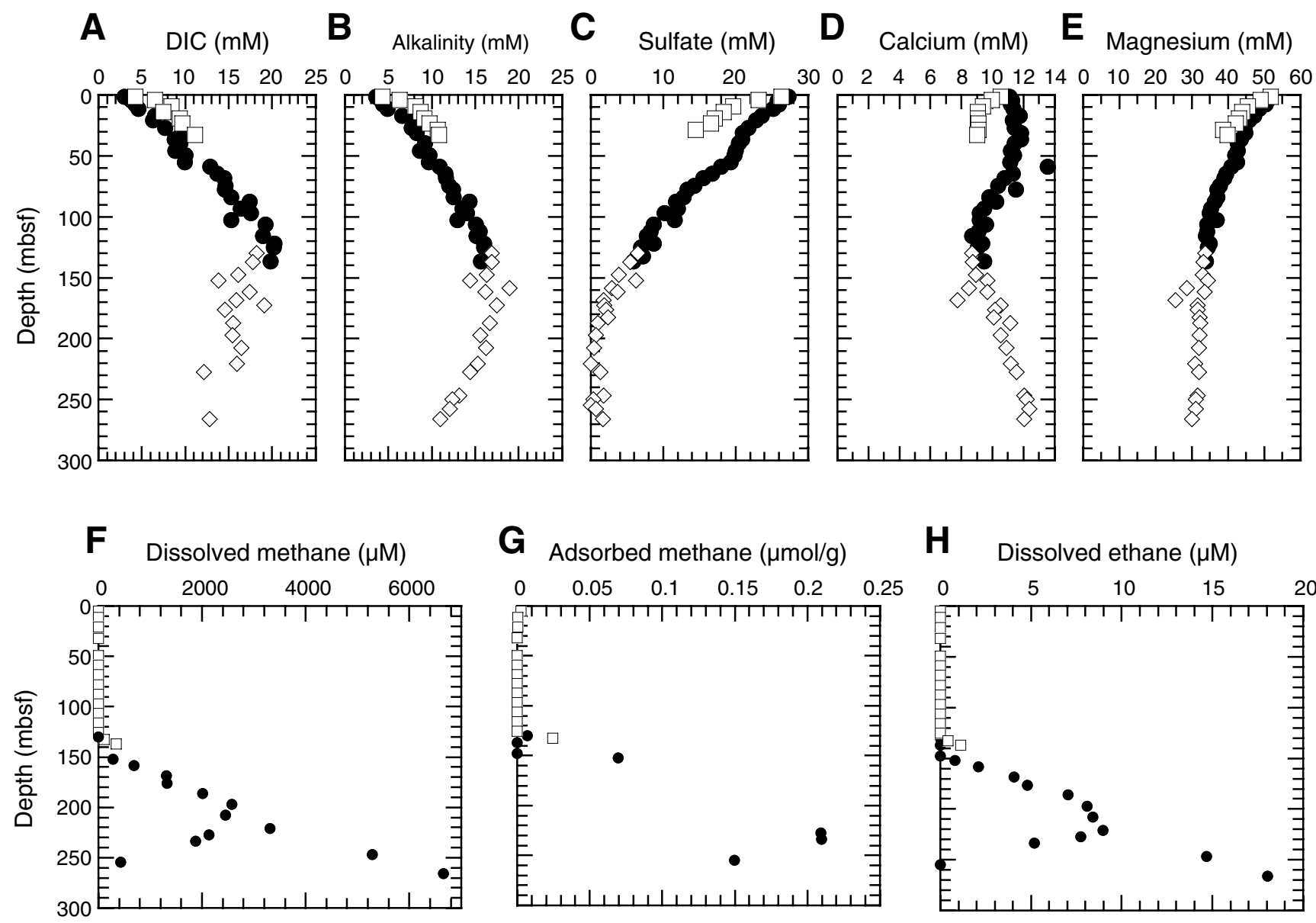

G Adsorbed methane $(\mu \mathrm{mol} / \mathrm{g})$

H Dissolved ethane ( $\mu \mathrm{M})$
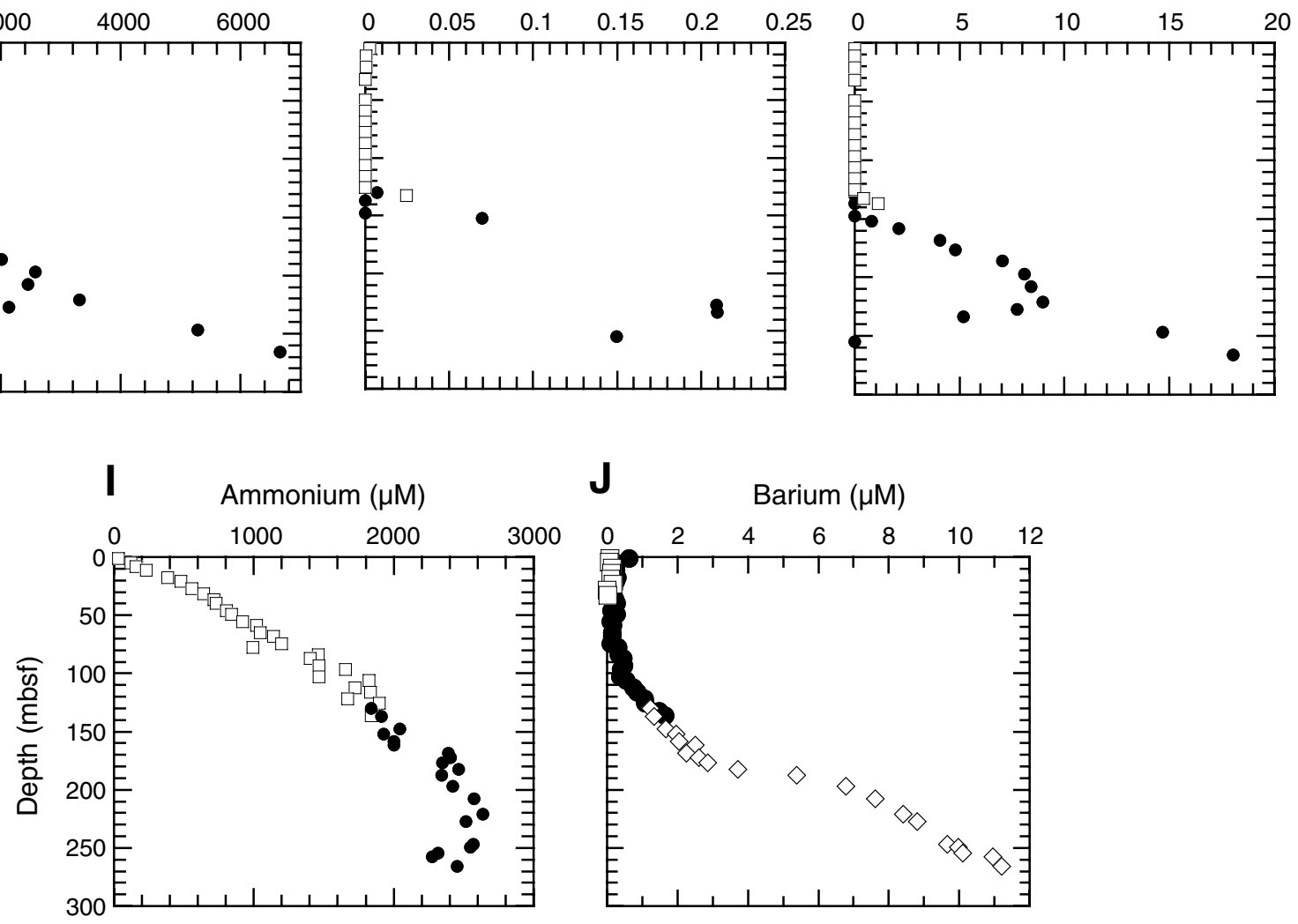
Figure F18. Carbonate content vs. depth in Hole U1317A.

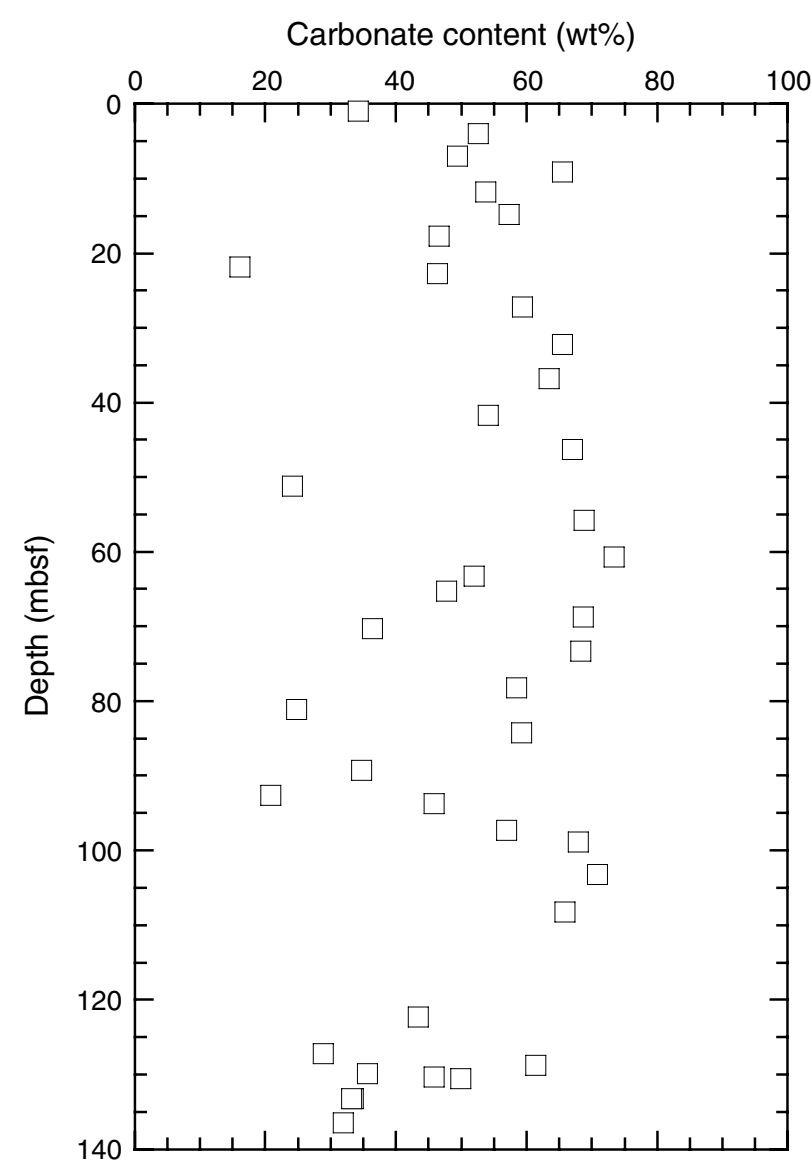


Figure F19. Graphic representation of subsampling and analysis program for the MBIO core sections from Hole U1317A. The sequence of subsections runs from the top of the core (right) toward the bottom (left). See Table T4 in the "Methods" chapter for explanation of sampling codes.

\begin{tabular}{|c|c|c|c|c|c|c|c|c|c|}
\hline 307-U1317A & \multicolumn{7}{|c|}{ CATWALK } & \multirow{2}{*}{\multicolumn{2}{|c|}{ Core depth }} \\
\hline CURATORS CODE & IW & AODC & CONT-PFCCONT-BEAD & HS & $\mathrm{CH} 4$ & DEL & HGA & & \\
\hline abprox. sample size $(\mathrm{cm})$ & 10 & 1 & & & & & & & \\
\hline Sample Type & WRC & 1 syringe & 1 syringe & 1 syringe & 1 syringe & 1 syringe & 1 syringe & & \\
\hline $\begin{array}{l}\text { Sampie ype } \\
\text { Core }\end{array}$ & $190-200 \mathrm{~cm}$ & & 1 syminge & $\begin{array}{ll}185-15 \\
185\end{array}$ & $\mathrm{~cm}$ & 7 syminge & Isylmige & top & bottom \\
\hline $1 \mathrm{H}$ & 1 & 1 & 1 & 1 & 1 & 1 & 1 & 0.00 & 6.50 \\
\hline $2 \mathrm{H}$ & 1 & 1 & 1 & 1 & 1 & 1 & 1 & 6.50 & 16.00 \\
\hline $3 \mathrm{H}$ & 1 & 1 & 1 & 1 & 1 & 1 & 1 & 16.00 & 25.50 \\
\hline $4 \mathrm{H}$ & 1 & 1 & 1 & 1 & 1 & 1 & 1 & 25.50 & 35.00 \\
\hline $5 \mathrm{H}$ & 1 & 1 & 1 & 1 & 1 & 1 & 1 & 35.00 & 44.50 \\
\hline $6 \mathrm{H}$ & 1 & 1 & 1 & 1 & 1 & 1 & 1 & 44.50 & 54.00 \\
\hline $7 \mathrm{H}$ & 1 & 1 & 1 & 1 & 1 & 1 & 1 & 54.00 & 63.50 \\
\hline $8 \mathrm{H}$ & 1 & 1 & 1 & 1 & 1 & 1 & 1 & 63.50 & 73.00 \\
\hline $9 \mathrm{H}$ & 1 & 1 & 1 & 1 & 1 & 1 & 1 & 73.00 & 82.50 \\
\hline $10 \mathrm{H}$ & 1 & 1 & 1 & 1 & 1 & 1 & 1 & 82.50 & 92.00 \\
\hline $11 \mathrm{H}$ & 1 & 1 & 1 & 1 & 1 & 1 & 1 & 92.00 & 101.50 \\
\hline $12 \mathrm{H}$ & 1 & 1 & 1 & 1 & 1 & 1 & 1 & 101.50 & 111.00 \\
\hline $13 \mathrm{H}$ & 1 & 1 & 1 & 1 & 1 & 1 & 1 & 111.00 & 120.50 \\
\hline $14 \mathrm{H}$ & 1 & 1 & 1 & 1 & 1 & 1 & 1 & 120.50 & 130.00 \\
\hline $17 \mathrm{X}$ & 1 & 1 & 1 & 1 & 1 & 1 & 1 & 130.80 & 136.30 \\
\hline $18 \mathrm{X}$ & 1 & 1 & 1 & 1 & 1 & 1 & 1 & 136.30 & 138.80 \\
\hline TOTAL & 16 & 16 & 16 & 16 & 16 & 16 & 16 & 128 & Samples \\
\hline
\end{tabular}

\begin{tabular}{|c|c|c|c|c|c|c|c|c|c|c|c|c|c|c|c|c|c|c|c|c|}
\hline 307-U1317A & \multicolumn{18}{|c|}{ COLDROOM } & & \\
\hline CURATORS CODE & AOM & SRR & $\mathrm{CH} 4 \mathrm{C}$ & URI & GAS & VIR & FISH & DNAI & DNAPCR & DNAS & DNAG & DNAIODP & DNAC & AALEO & $\mathrm{LIPH}$ & WRCB & LIPD & MICT & \multicolumn{2}{|c|}{ Core depth } \\
\hline approx. sample size $(\mathrm{cm})$ & 30 & 10 & 20 & 5 & 6 & 5 & 5 & 5 & 5 & 5 & 5 & 5 & 10 & 5 & 12 & 30 & 5 & 5 & \multirow{3}{*}{\multicolumn{2}{|c|}{ mbst }} \\
\hline storage & \multicolumn{4}{|c|}{ Aluminium bag, $\mathrm{N}_{2}, 4^{\circ} \mathrm{C}$, anoxic } & $\begin{array}{l}\text { can, } 4^{\circ} \mathrm{C}, \\
\text { poisoned }\end{array}$ & AL-bag, I & ${ }^{\circ} \mathrm{C}$, anox & \multicolumn{8}{|c|}{ Poly-bag, $-80^{\circ} \mathrm{C}$} & $4^{\circ} \mathrm{C}$ & $\begin{array}{c}\text { Poly } \\
\text { bag, } \\
-80^{\circ} \mathrm{C}\end{array}$ & $4^{\circ} \mathrm{C}$ & & \\
\hline Sample Type & WRC & WRC & WRC & WRC & WRC & WRC & WRC & WRC & WRC & WRC & WRC & WRC & WRC & WRC & WRC & WRC & WRC & WRC & & \\
\hline Core & & & & & & & & & & & & & & & & & & & top & bottom \\
\hline $1 \mathrm{H}$ & 1 & 1 & 1 & 1 & 1 & 1 & 1 & 1 & 1 & 1 & 1 & 1 & 1 & 3 & 1 & - & 1 & 1 & 0.00 & 6.50 \\
\hline $2 \mathrm{H}$ & 1 & 1 & 1 & 1 & 1 & 1 & 1 & 1 & 1 & - & 1 & 1 & 1 & 3 & 1 & - & 1 & 1 & 6.50 & 16.00 \\
\hline $3 \mathrm{H}$ & 1 & 1 & 1 & 1 & 1 & 1 & 1 & 1 & 1 & - & 1 & 1 & 1 & 3 & 1 & - & 1 & 1 & 16.00 & 25.50 \\
\hline $4 \mathrm{H}$ & 1 & 1 & 1 & 1 & 1 & 1 & 1 & 1 & 1 & - & 1 & 1 & 1 & 3 & 1 & - & 1 & 1 & 25.50 & 35.00 \\
\hline $5 \mathrm{H}$ & 1 & 1 & 1 & 1 & 1 & - & - & 1 & - & - & 1 & 1 & 1 & 1 & 1 & - & 1 & 1 & 35.00 & 44.50 \\
\hline $6 \mathrm{H}$ & 1 & 1 & 1 & 1 & 1 & 1 & 1 & 1 & 1 & 1 & 1 & 1 & 1 & 1 & 1 & - & 1 & 1 & 44.50 & 54.00 \\
\hline $7 \mathrm{H}$ & 1 & 1 & 1 & 1 & 1 & - & - & 1 & - & - & 1 & 1 & 1 & 1 & 1 & - & 1 & 1 & 54.00 & 63.50 \\
\hline $8 \mathrm{H}$ & 1 & 1 & 1 & 1 & 1 & - & - & 1 & - & - & 1 & 1 & 1 & 3 & 1 & - & 1 & 1 & 63.50 & 73.00 \\
\hline $9 \mathrm{H}$ & 1 & 1 & 1 & 1 & 1 & 1 & 1 & - & 1 & 1 & 1 & 1 & 1 & 3 & 1 & - & 1 & 1 & 73.00 & 82.50 \\
\hline $10 \mathrm{H}$ & 1 & 1 & 1 & 1 & 1 & - & - & 1 & - & - & 1 & 1 & 1 & 3 & 1 & - & 1 & 1 & 82.50 & 92.00 \\
\hline $11 \mathrm{H}$ & 1 & 1 & 1 & 1 & 1 & 1 & - & - & - & - & 1 & 1 & 1 & 3 & 1 & - & 1 & 1 & 92.00 & 101.50 \\
\hline $12 \mathrm{H}$ & 1 & 1 & 1 & 1 & 1 & - & 1 & 1 & 1 & - & 1 & 1 & 1 & 3 & 1 & - & 1 & 1 & 101.50 & 111.00 \\
\hline $13 \mathrm{H}$ & 1 & 1 & 1 & 1 & 1 & - & - & - & - & - & 1 & 1 & 1 & 3 & 1 & - & 1 & 1 & 111.00 & 120.50 \\
\hline $14 \mathrm{H}$ & 1 & 1 & 1 & 1 & 1 & - & - & 1 & - & - & 1 & 2 & 1 & 3 & 1 & - & 1 & 1 & 120.50 & 130.00 \\
\hline $17 X$ & 1 & 1 & 1 & 1 & 1 & - & - & 1 & - & - & 1 & 1 & 1 & 1 & 1 & - & 1 & 1 & 130.80 & 136.30 \\
\hline TOTAL & 15 & 15 & 15 & 15 & 15 & 7 & 7 & 12 & 7 & 3 & 15 & 16 & 15 & 37 & 15 & 0 & 15 & 15 & 239 & Sample \\
\hline
\end{tabular}


Figure F20. Graphic representation of subsampling and analysis program for the MBIO core sections from Hole U1317D. The sequence of subsections runs from the top of the core (right) toward the bottom (left). See Table T4 in the "Methods" chapter for explanation of sampling codes.

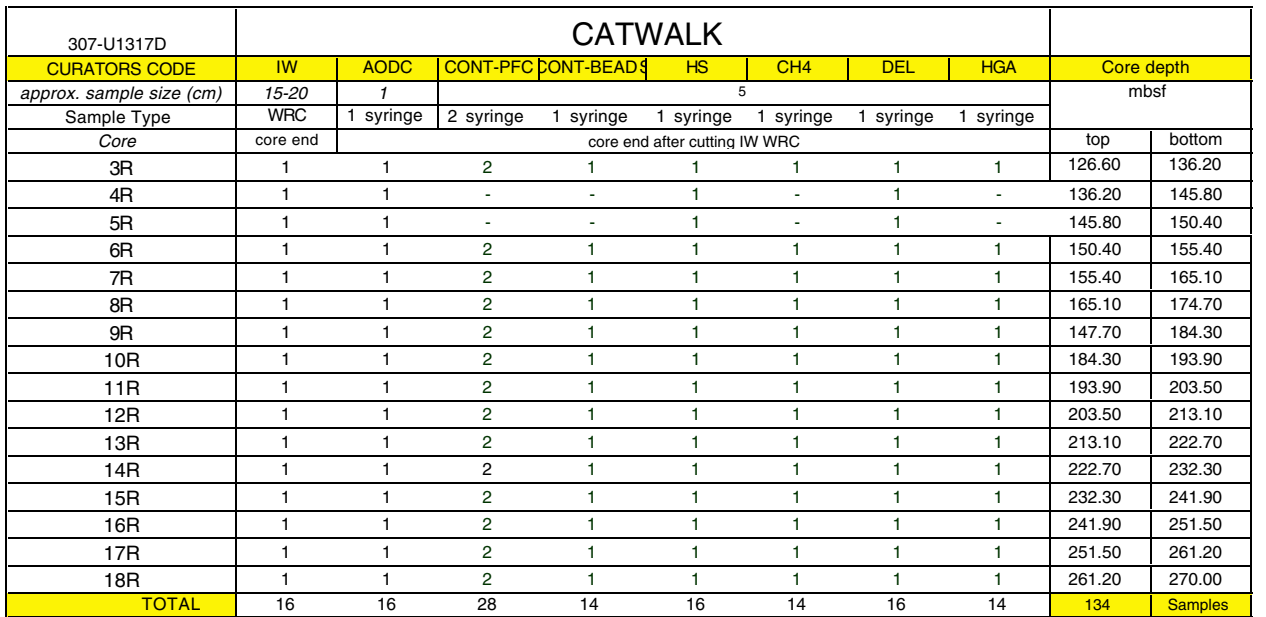

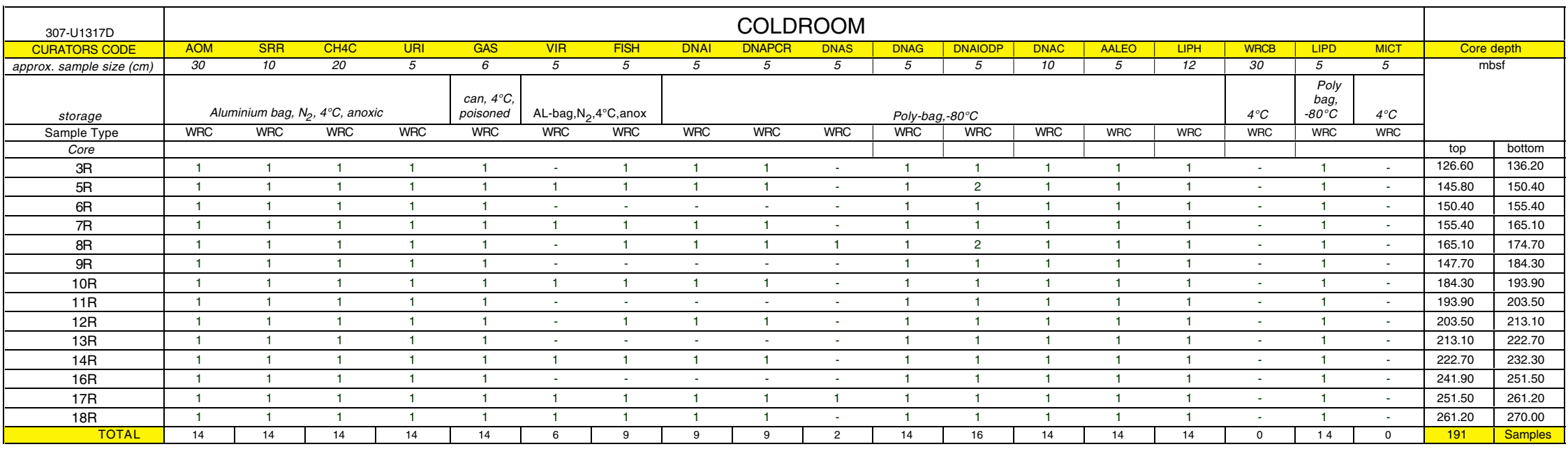


Figure F21. A. Total prokaryotic cells (solid circles) vs. depth. Dotted line = global prokaryote profile (Parkes et al., 2000) $\left(\log _{10}\right.$ cells $=8.03-0.66 \times \log _{10}$ depth $\left.[\mathrm{m}]\right)$, dashed lines $=$ upper and lower prediction limits for this profile, vertical line $=$ detection limit (5.2). B. Percentage of total population involved in cell division vs. depth. C. Geochemical profiles of sulfate (solid squares) and methane (crossed squares). Shaded section = area of significant methane concentrations.

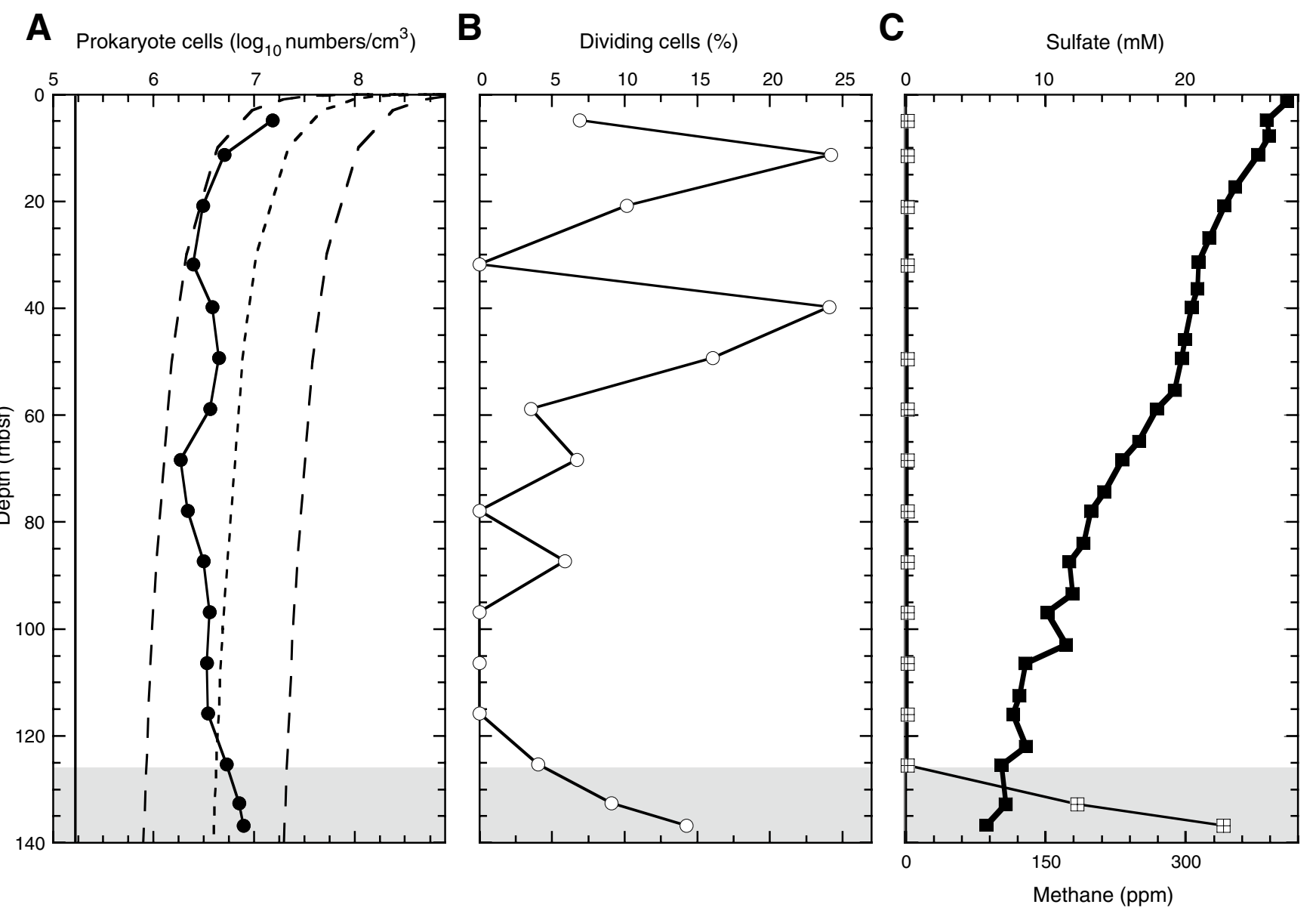


Figure F22. Depth curves of physical properties in Hole U1317A. GRA $=$ gamma ray attenuation, $\mathrm{PWL}=P$-wave logger, $\mathrm{PWS}=P$-wave sensor, red lines = running mean. Numbers next to NGR data are a preliminary and informal numbering of stratigraphic cycles. PP $=$ physical property.

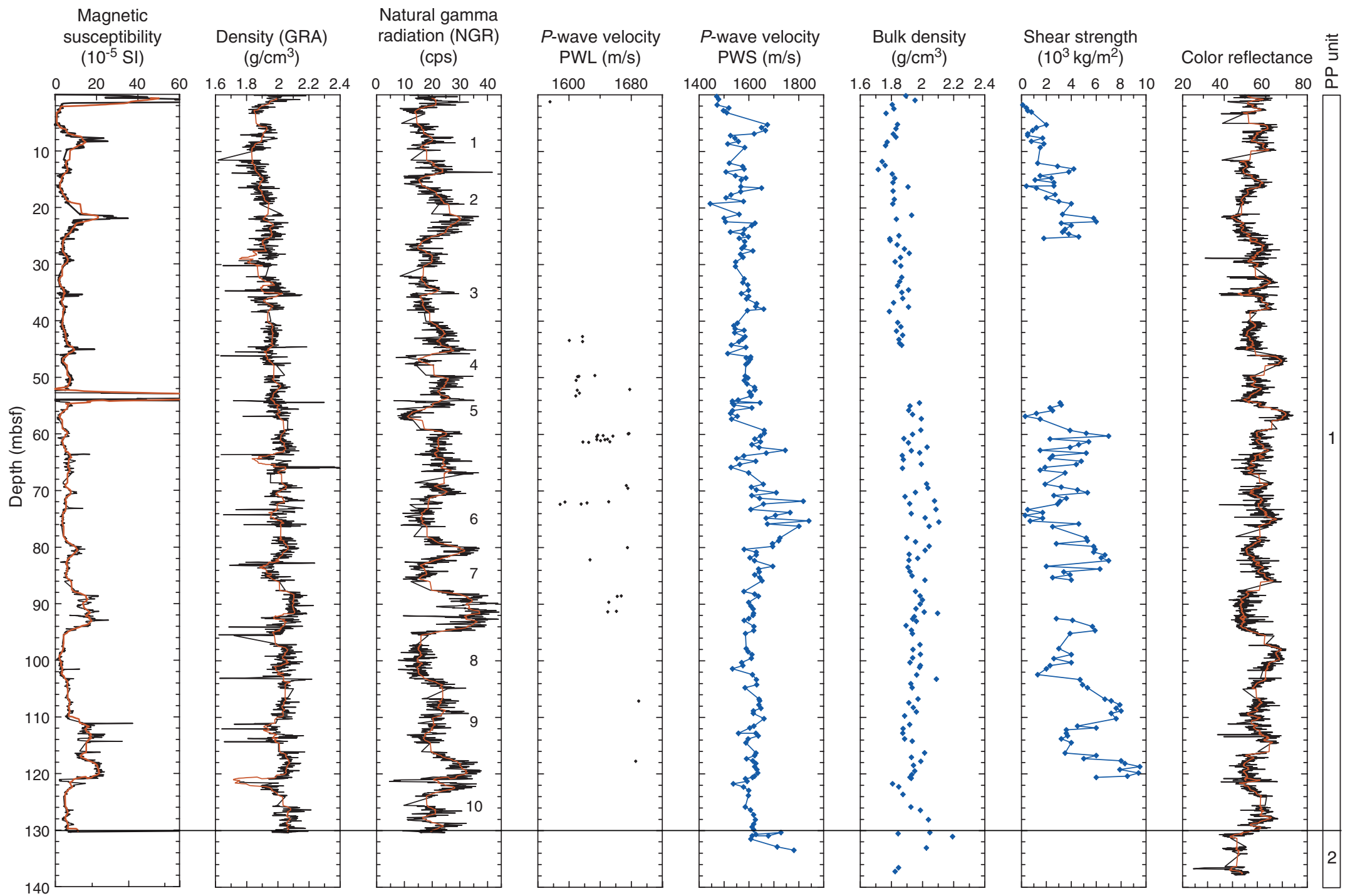


Figure F23. Depth curves of physical properties in Hole U1317B. GRA = gamma ray attenuation, $P W L=P$ wave logger, red lines = running mean. Numbers next to NGR data are a preliminary and informal numbering of stratigraphic cycles. $\mathrm{PP}=$ physical property.

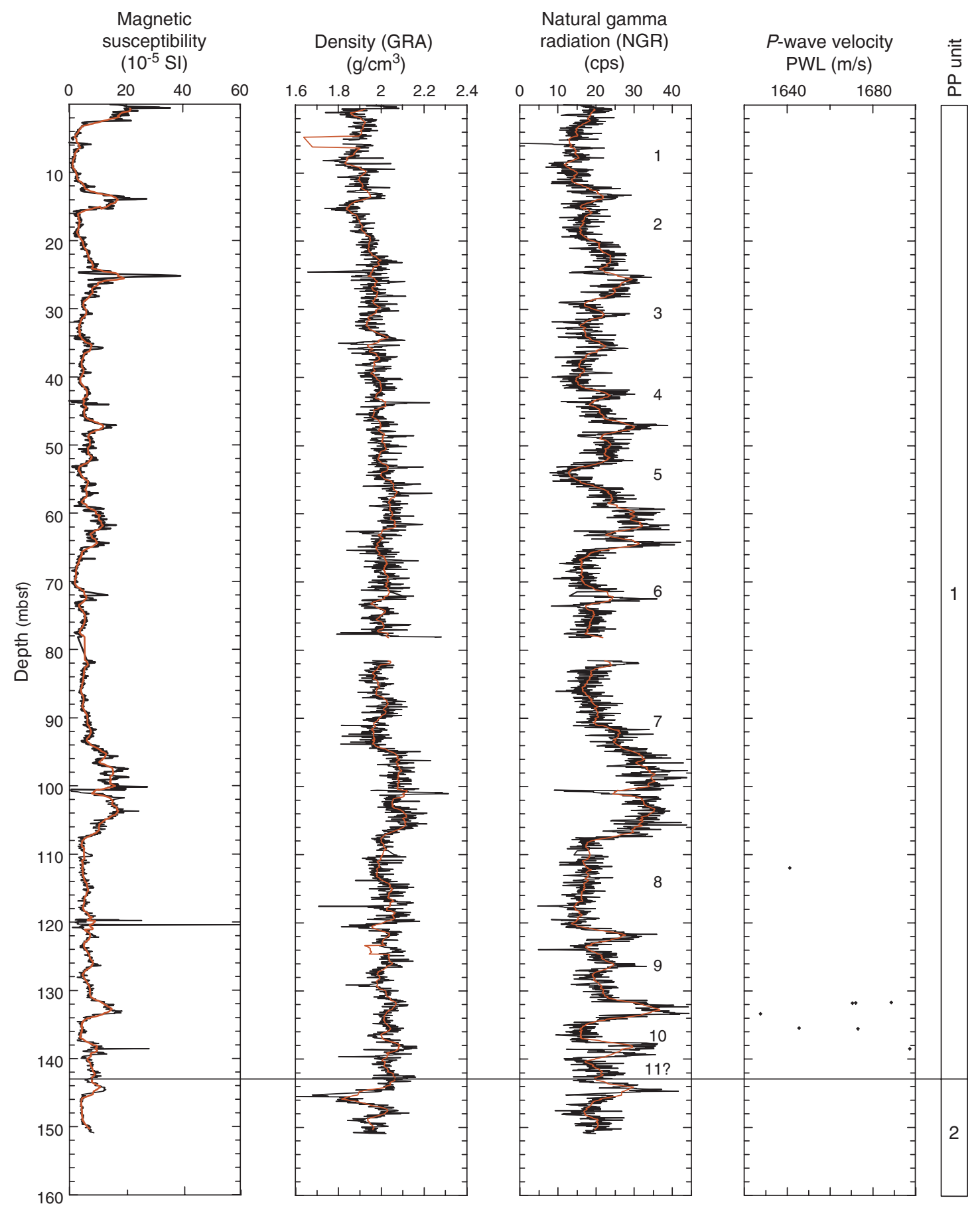


Figure F24. Depth curves of physical properties in Hole U1317C. GRA = gamma ray attenuation, PWL $=P$ wave logger, red lines = running mean. Numbers next to NGR data are a preliminary and informal numbering of stratigraphic cycles. $\mathrm{PP}=$ physical property.

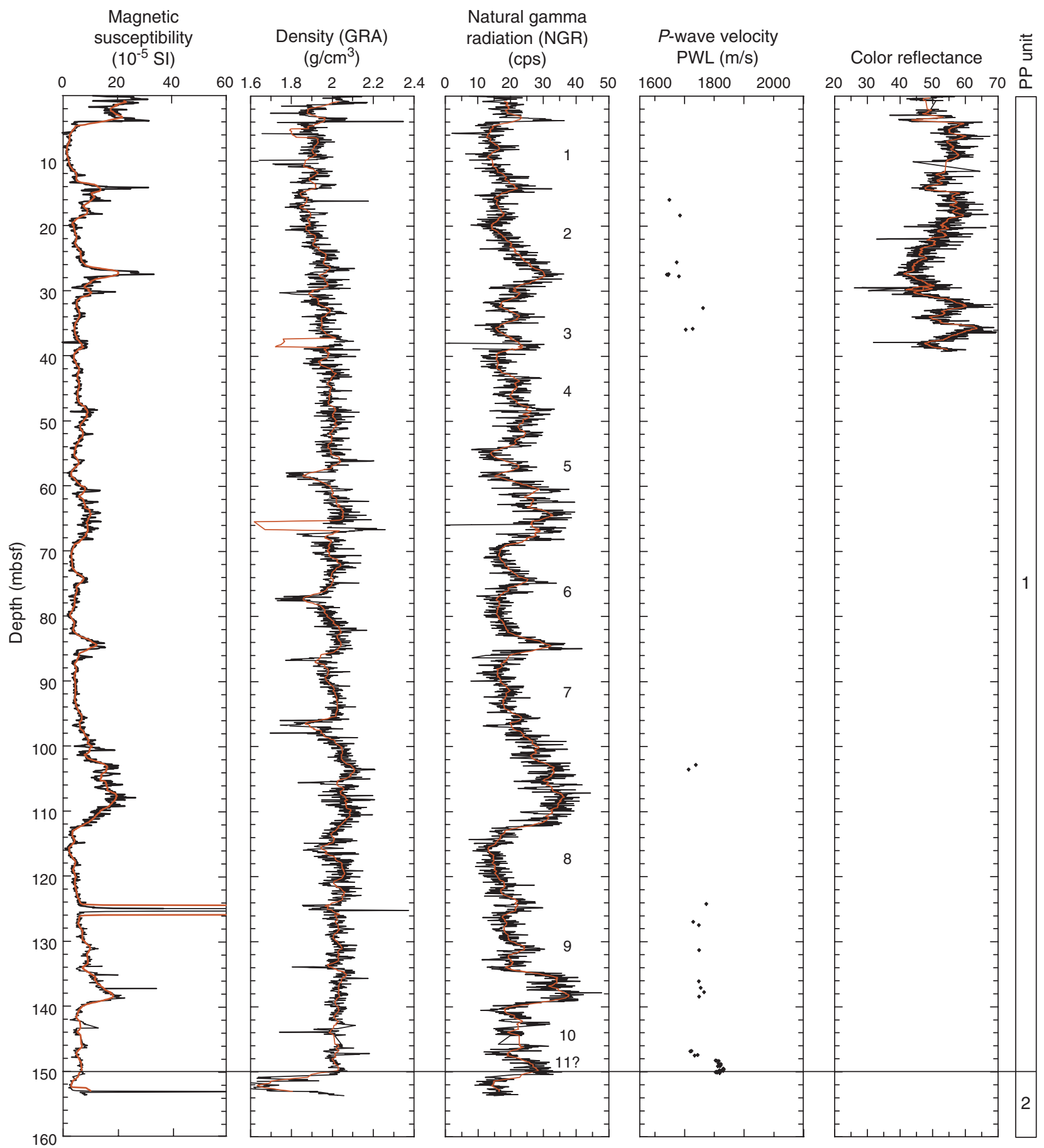


Figure F25. Depth curves of physical properties of Hole U1317D. GRA = gamma ray attenuation, PWS $=P$ wave sensor, red lines = running mean. Numbers next to NGR data are a preliminary and informal numbering of stratigraphic cycles. $\mathrm{PP}=$ physical property.

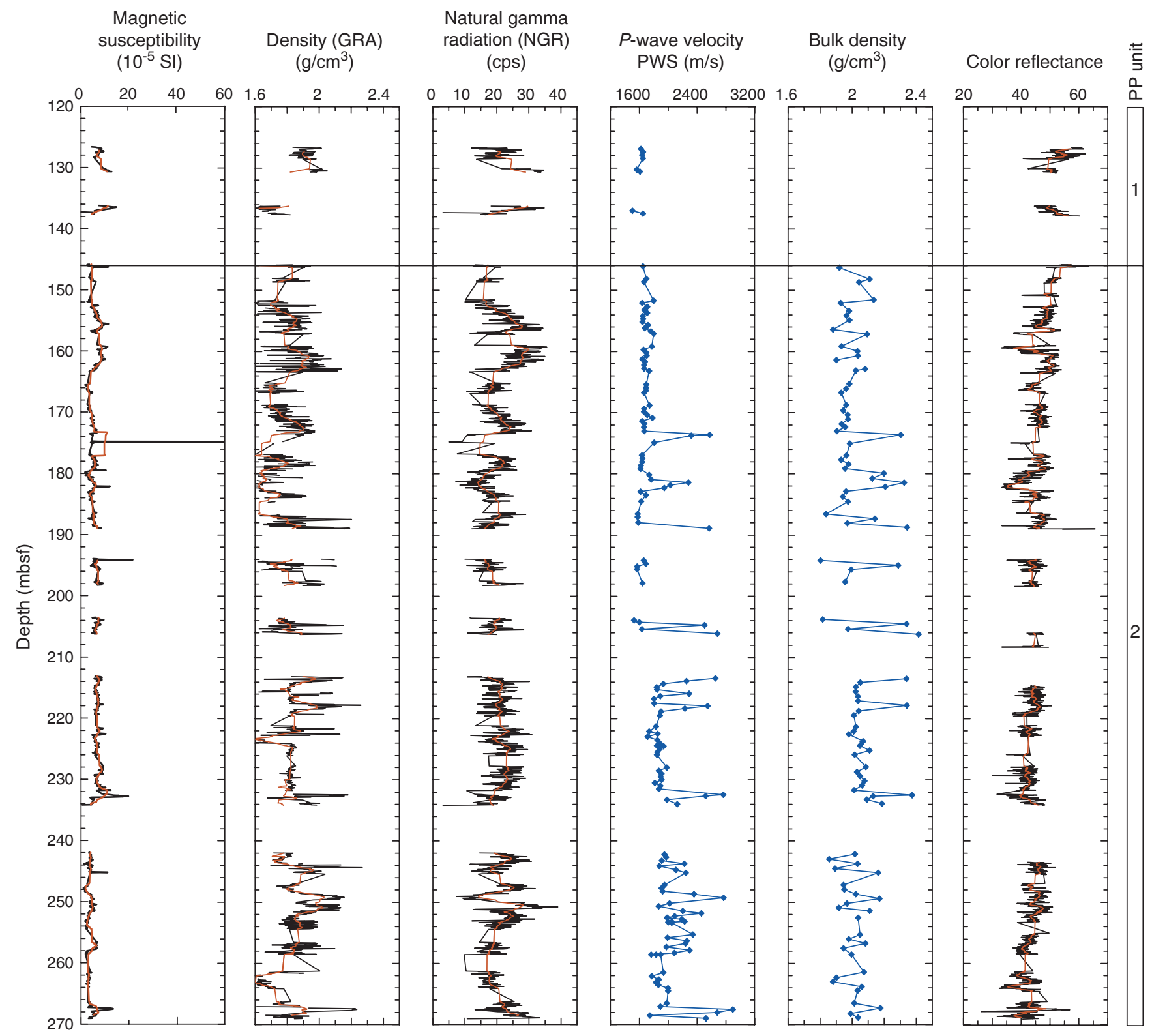


Figure F26. Depth curves of physical properties in Hole U1317E. GRA = gamma ray attenuation, red lines = running mean. Numbers next to NGR data are a preliminary and informal numbering of stratigraphic cycles. $\mathrm{PP}=$ physical property.

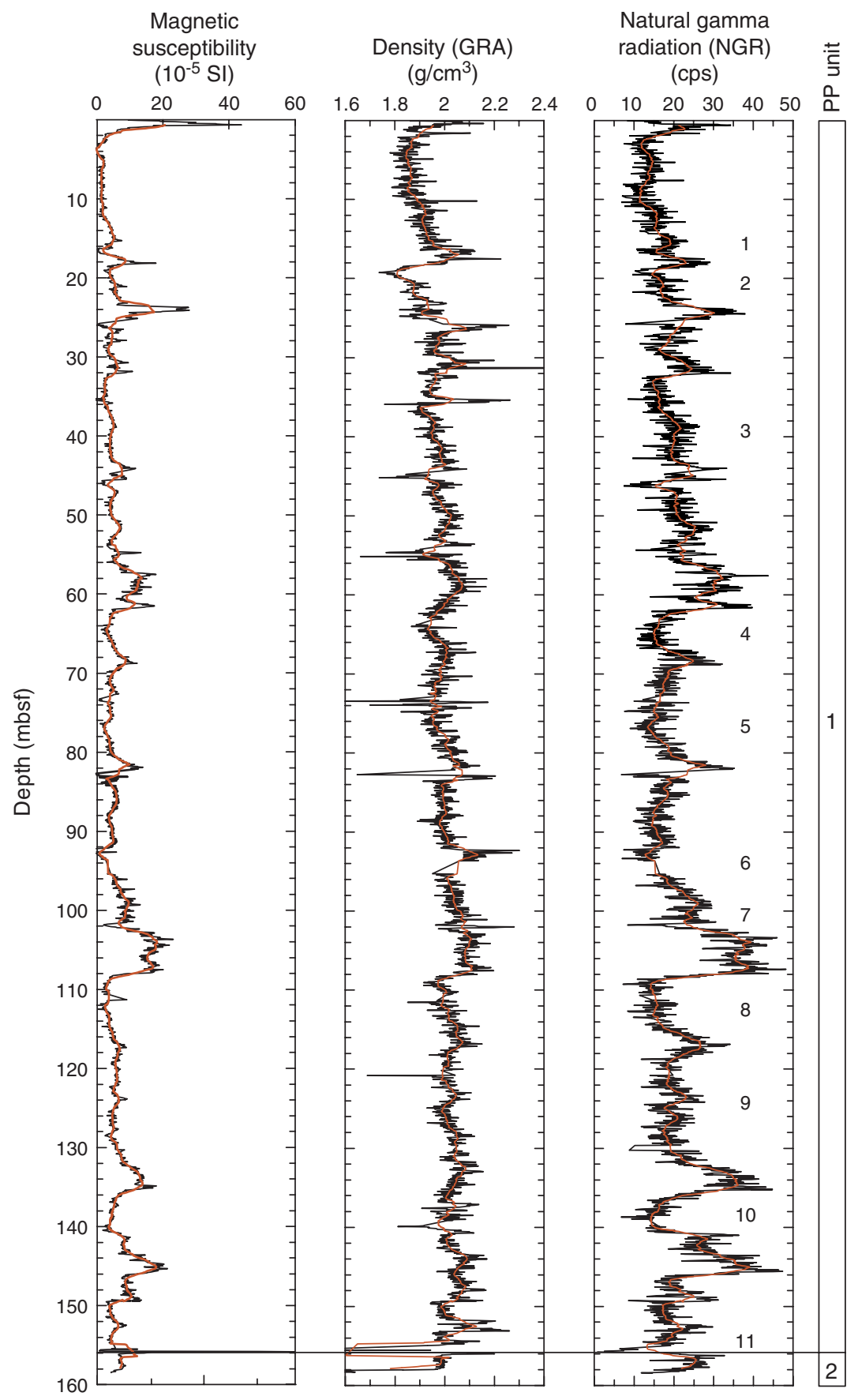


Figure F27. Discrete APCT tool measurements in Hole U1317A.

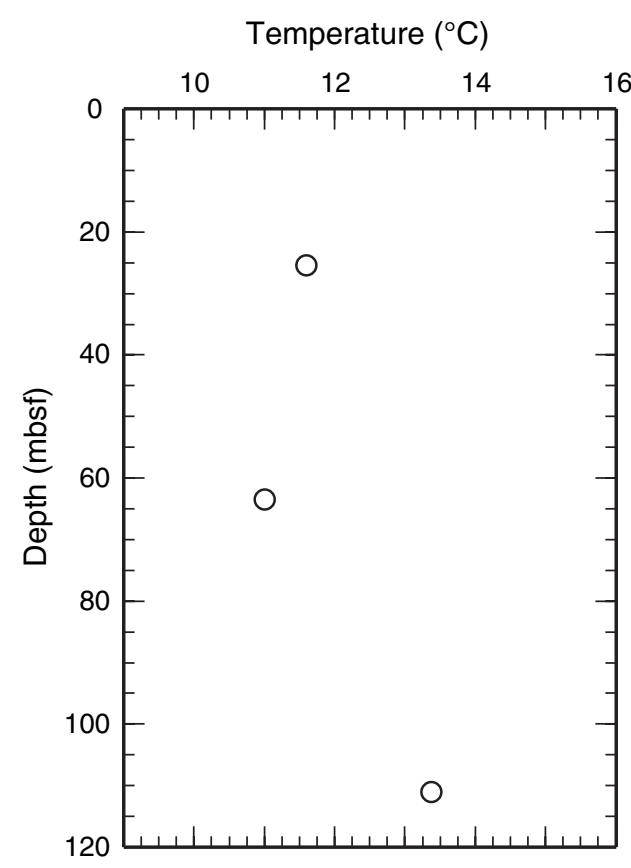


Figure F28. Thermal conductivity measurements in Hole U1317A compared with density. GRA = gamma ray attenuation.

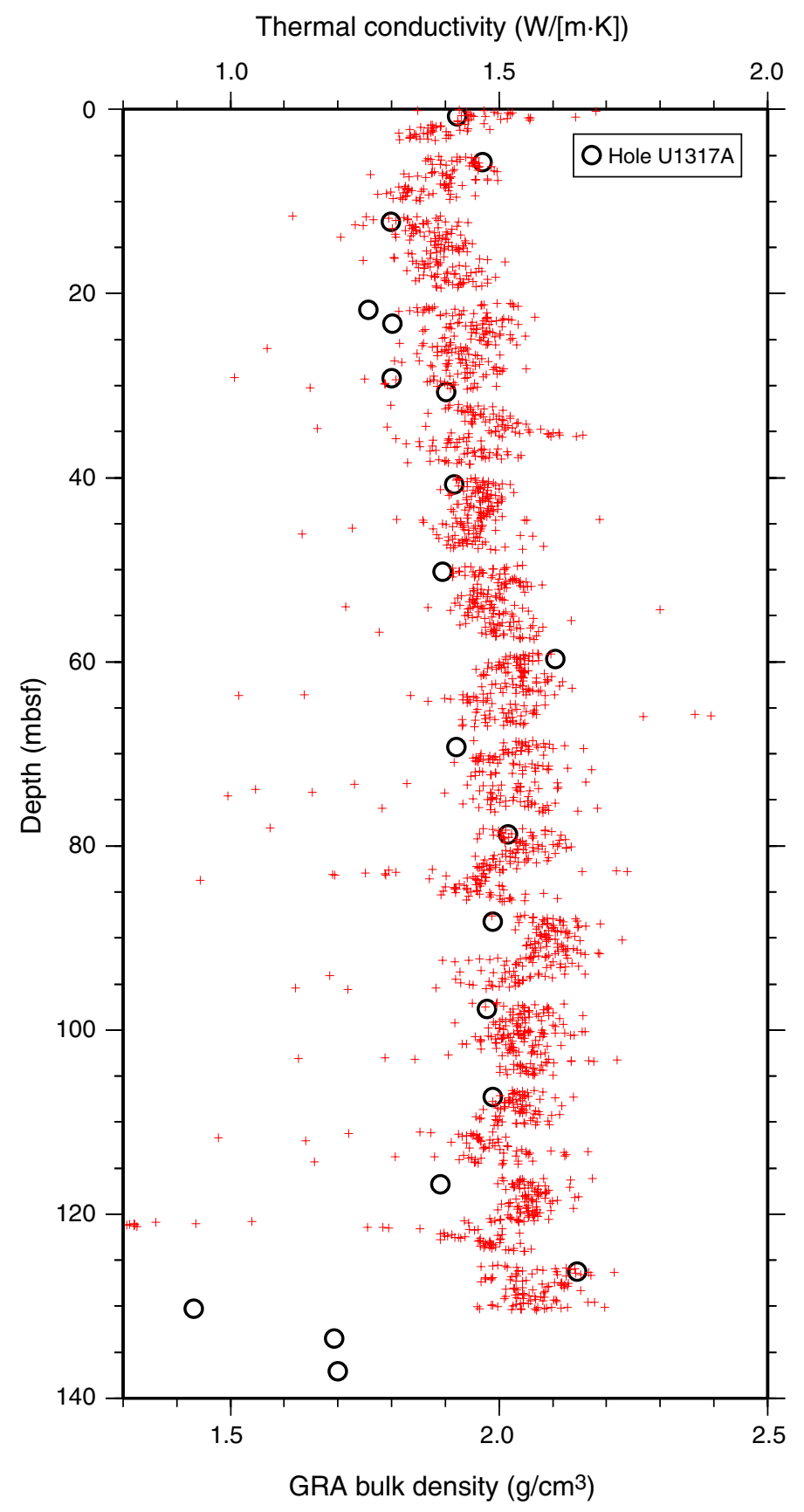


Figure F29. Correlation plots of physical properties in Hole U1317A. GRA = gamma ray attenuation, NGR = natural gamma radiation, $\mathrm{MAD}=$ moisture and density.

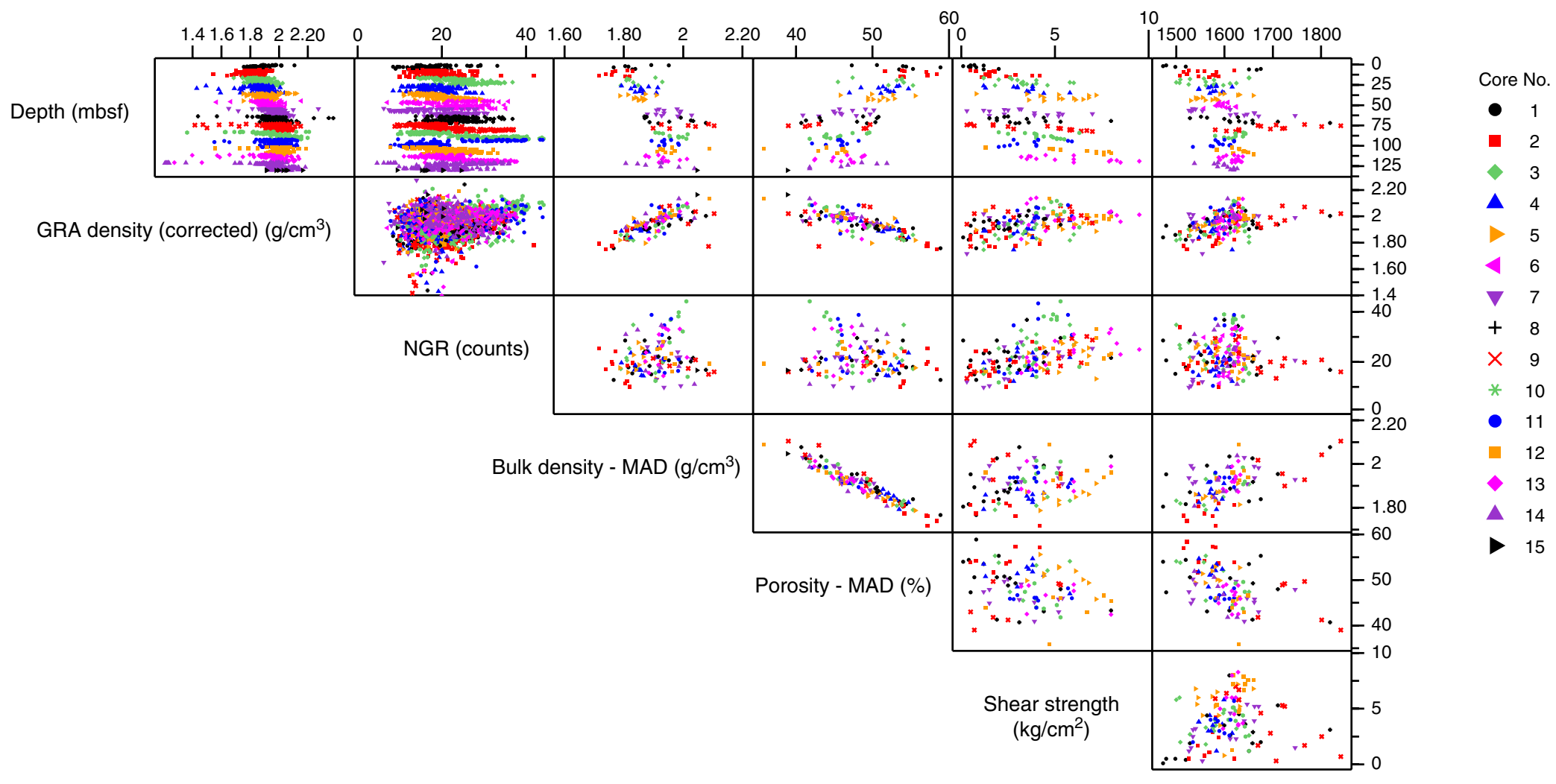

$P$-wave velocity $(\mathrm{m} / \mathrm{s})$ 
Figure F30. Natural gamma radiation (NGR) depth curves. Numbers next to the Hole U1317A NGR data are a preliminary and informal numbering of stratigraphic cycles.

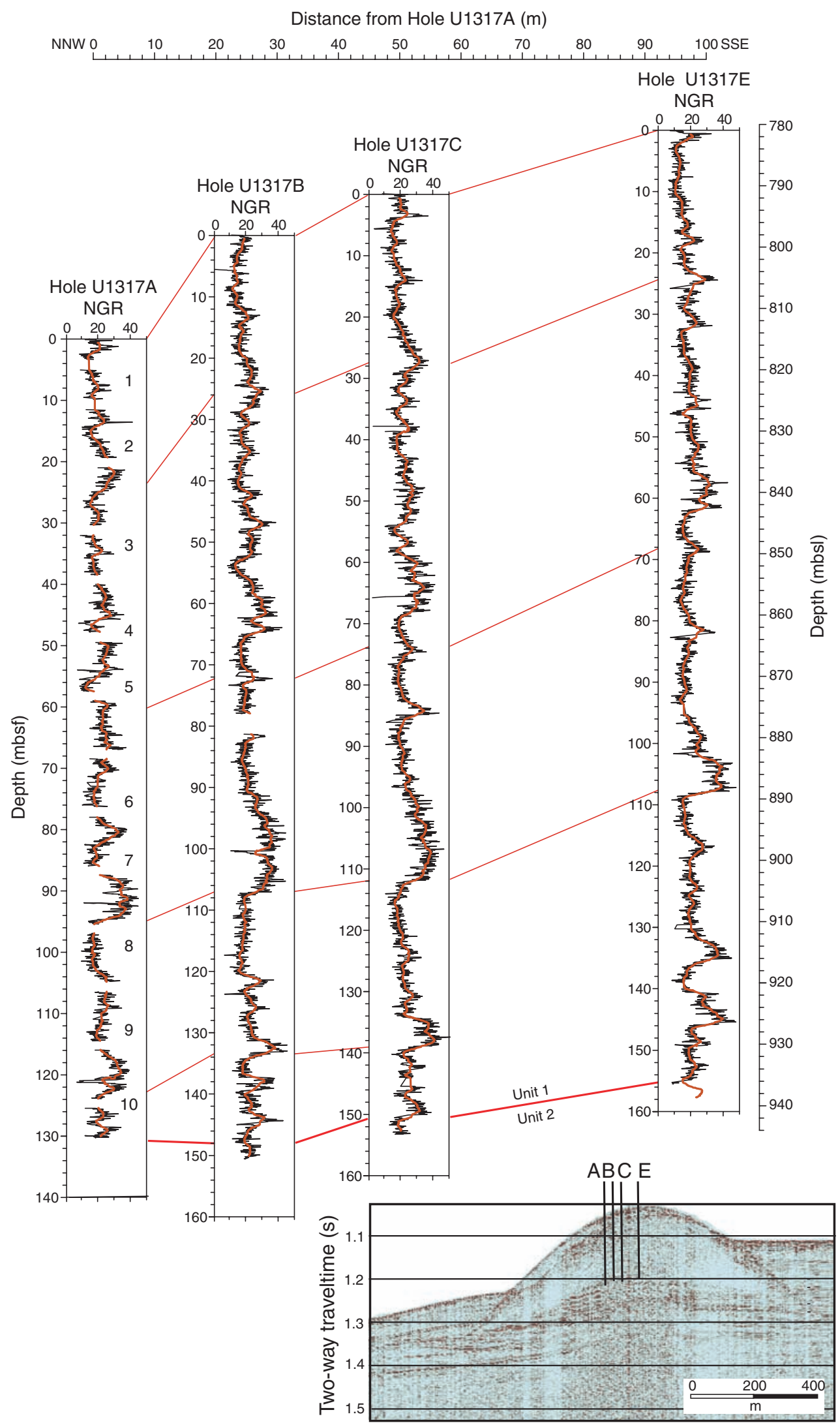


Figure F31. Summary of the logging operations in Hole U1317D. FMS = Formation MicroScanner.

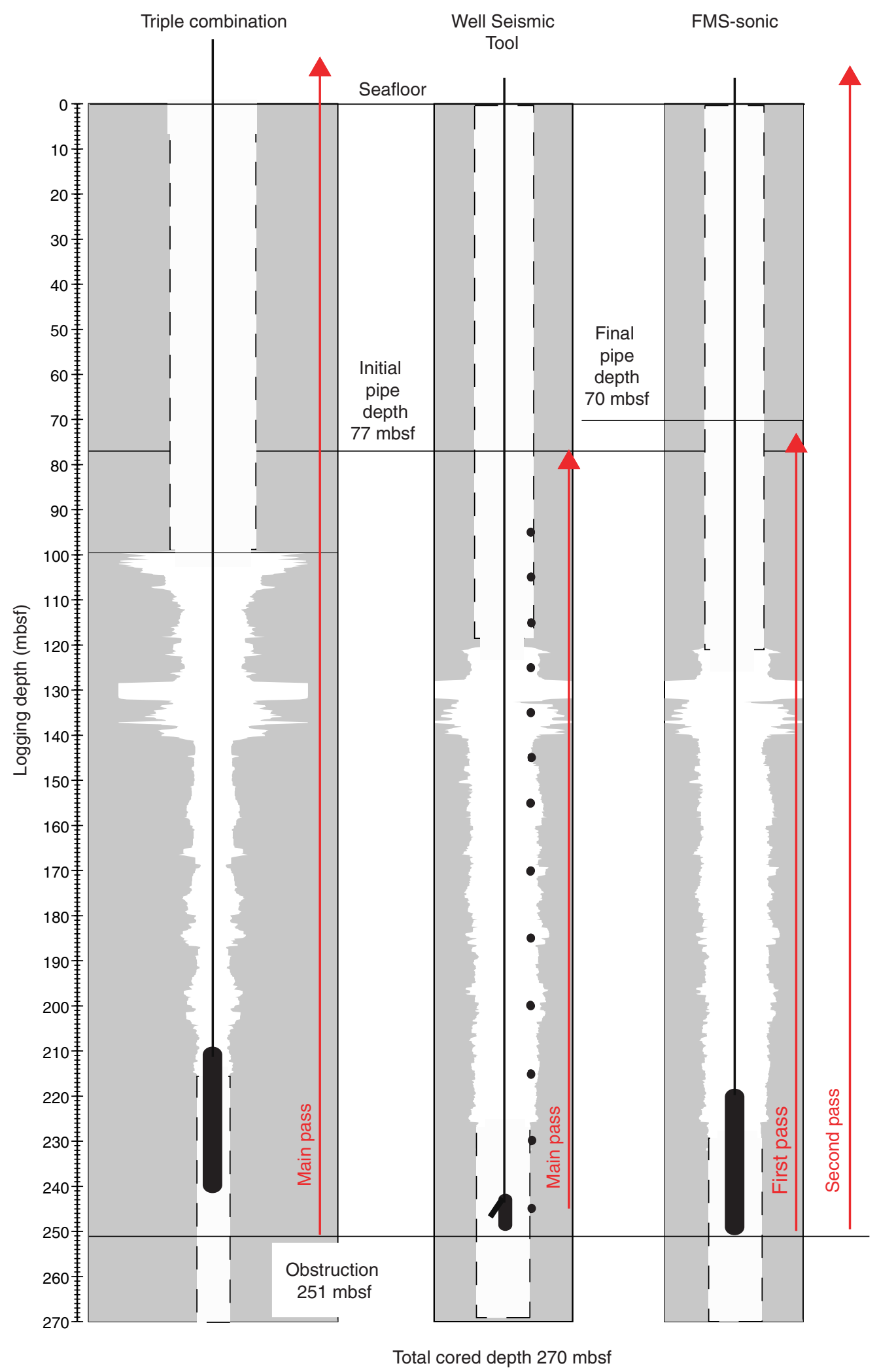


Figure F32. Quality control indicators for the triple combo and Formation MicroScanner (FMS)-sonic tool strings. Green = FMS-sonic Pass 1 (first pass), red = FMS-sonic Pass 2 (main pass). A. Triple combo caliper. B. Triple combo vertical tool acceleration $\left(A_{z}\right)$. C. FMS-sonic caliper. D. FMS-sonic vertical acceleration $\left(A_{z}\right)$. E. FMS-sonic horizontal acceleration $\left(A_{x}\right)$. F. FMS-sonic horizontal acceleration $\left(\mathrm{A}_{\mathrm{y}}\right)$. G. Hole azimuth (HAZI) and orientation (P1AZ) of the FMS-sonic tool string for Pass 1. H. HAZI and P1AZ of the FMS-sonic tool string for Pass 2. I. Angular difference $(\Delta)$ between the azimuths of the two FMS passes.

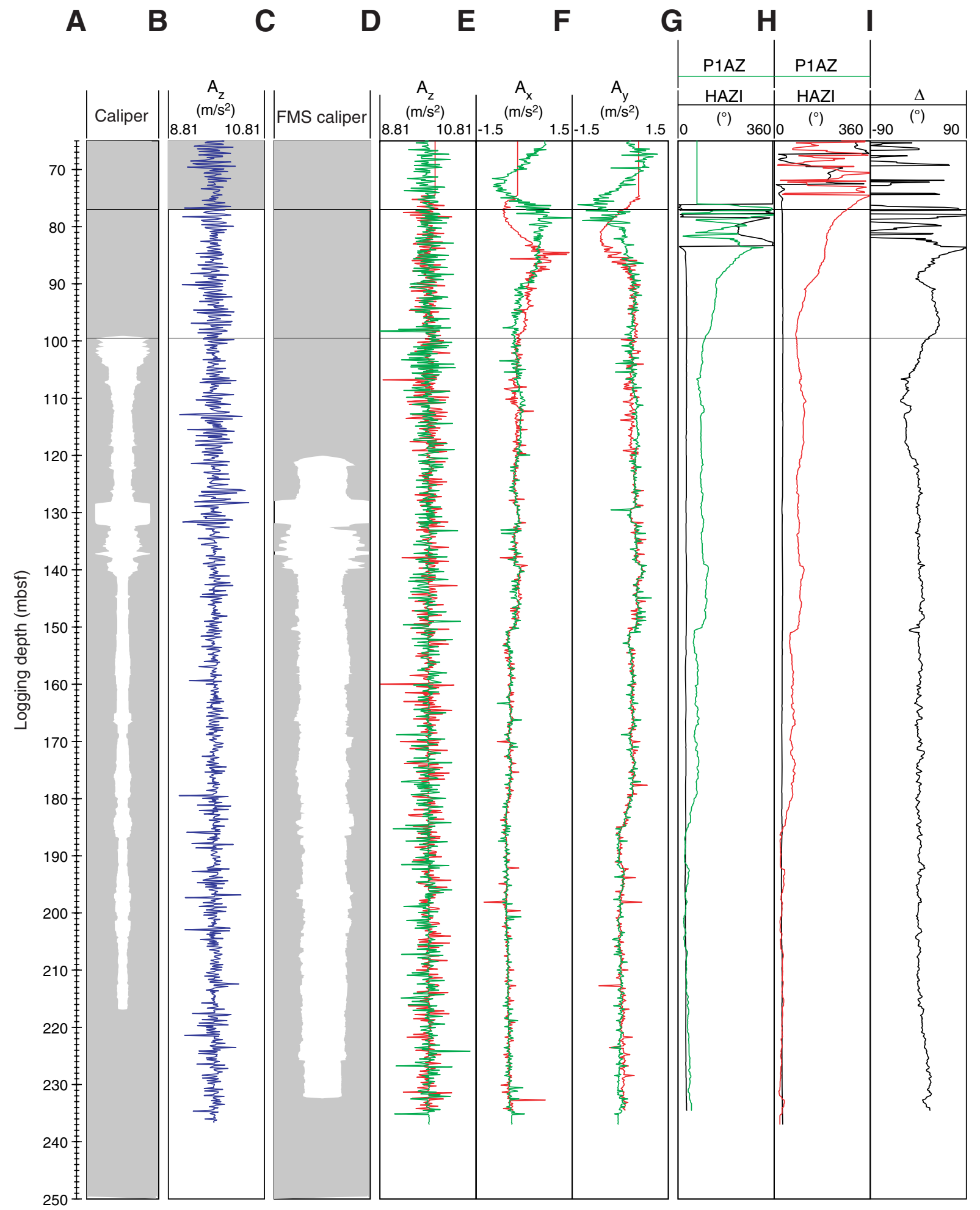


Figure F33. Depth-shifting. A. Triple combination (triple combo) tool string total gamma ray log (HSGR) used as reference for depth-shifting. B. Formation MicroScanner (FMS)-sonic tool string gamma ray log (ECGR) in respect to HSGR for Pass 1. C. The FMS-sonic tool string ECGR in respect to HSGR for Pass 2.

A

B

C

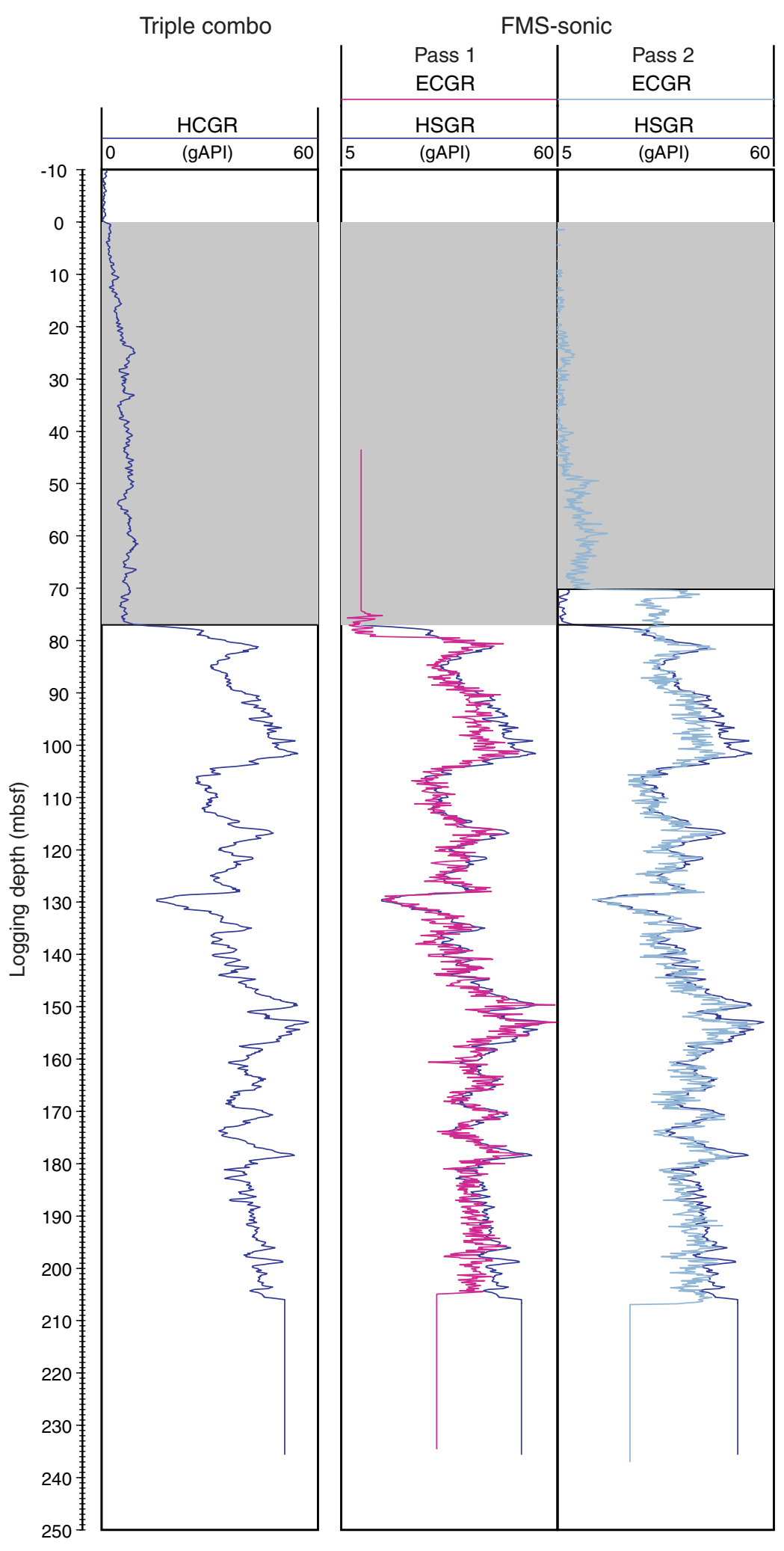


Figure F34. Log stratigraphy. A. Hole shape, total gamma ray and potassium content. B. Thorium and uranium. C. Deep, medium, and shallow resistivities. D. Porosity and formation density. E. Capture cross-section (SIGF) and photoelectric effect factor (PEF). F. Downhole compressional velocities $\left(V_{\mathrm{P}}\right)$ and interval velocity determined by the check shot survey. G. Logging subunits.

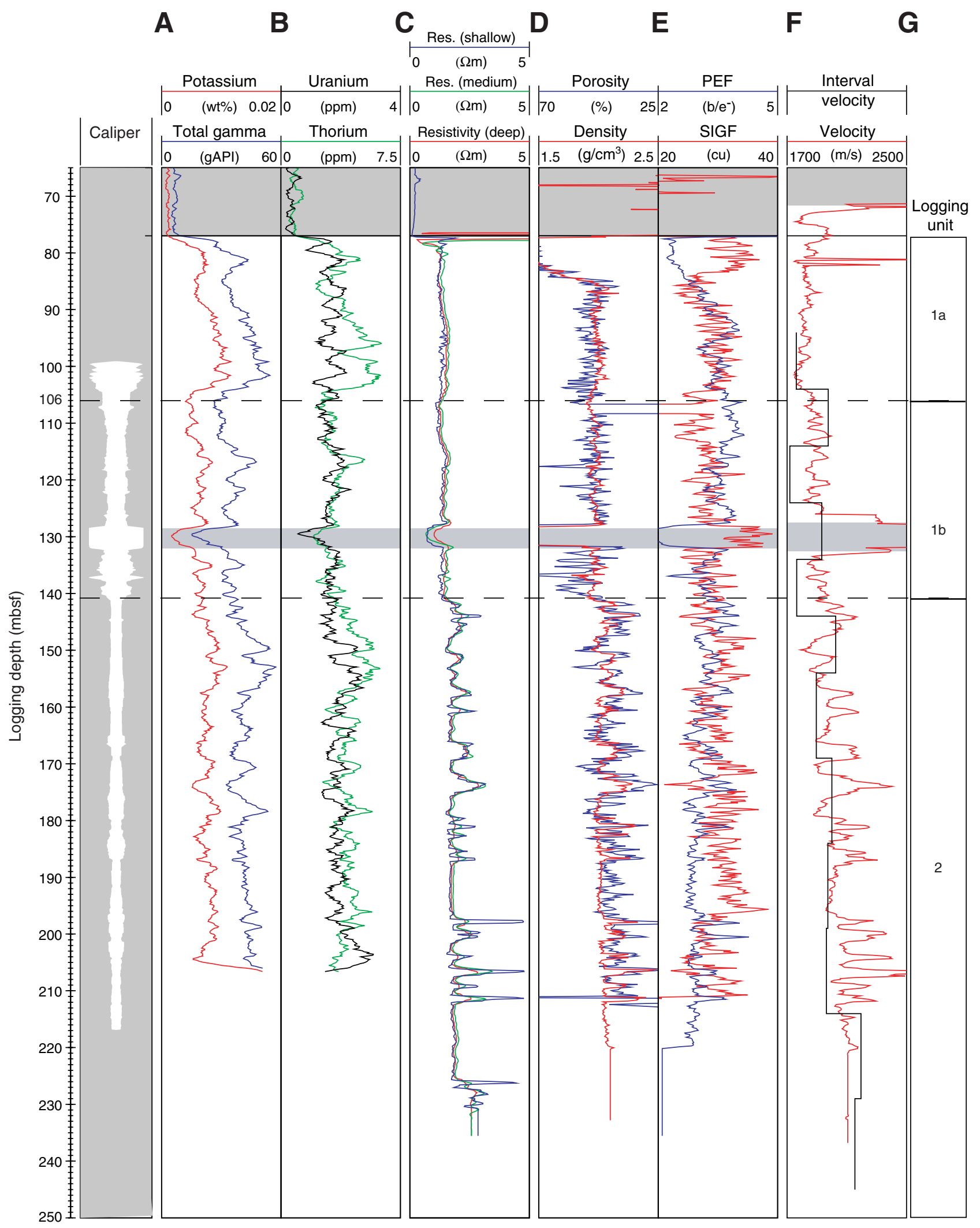


Figure F35. Core-log integration. Postcruise correlation between features recorded in these logs (especially acoustic, density, and gamma radiation) offer potential to provide in situ ground truth for core data. NGR = natural gamma radiation, HSGR = total spectral gamma radiation, APLC = porosity, GRA = gamma ray attenuation, $\mathrm{RHOM}=$ bulk density, $\mathrm{PWL}=P$-wave logger, $\mathrm{PWS}=P$-wave sensor.

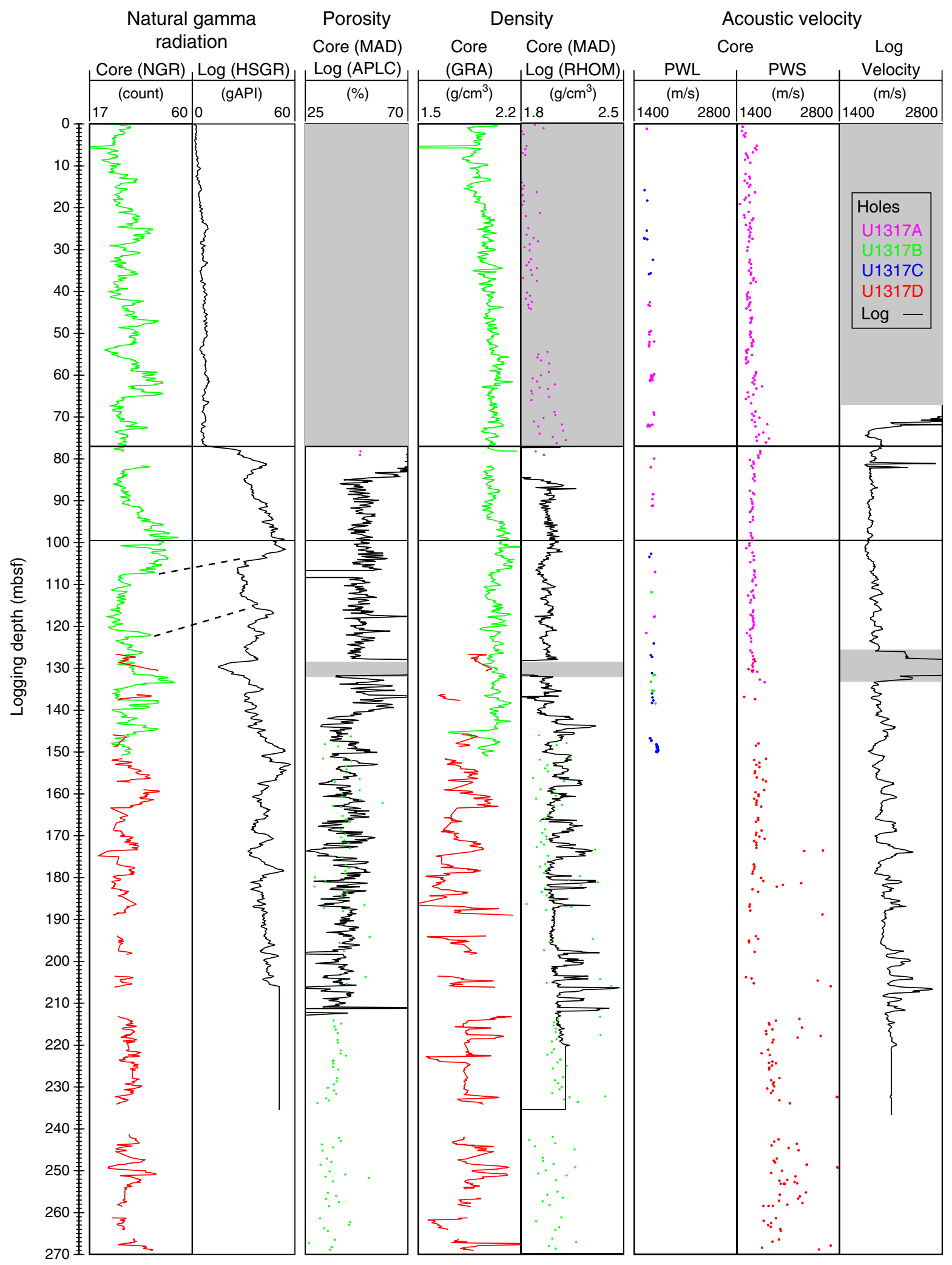


Figure F36. Thermal measurements. A. Drilling mud temperature measurements using the Environmental Measurement Sonde (EMS) (down logging) and Temperature/Acceleration/Pressure (TAP) tool compared to advanced piston corer temperature (APCT) tool measurements. B. Thermal conductivity measurements on core (discreet measurements) and APCT tool measurement (in situ).

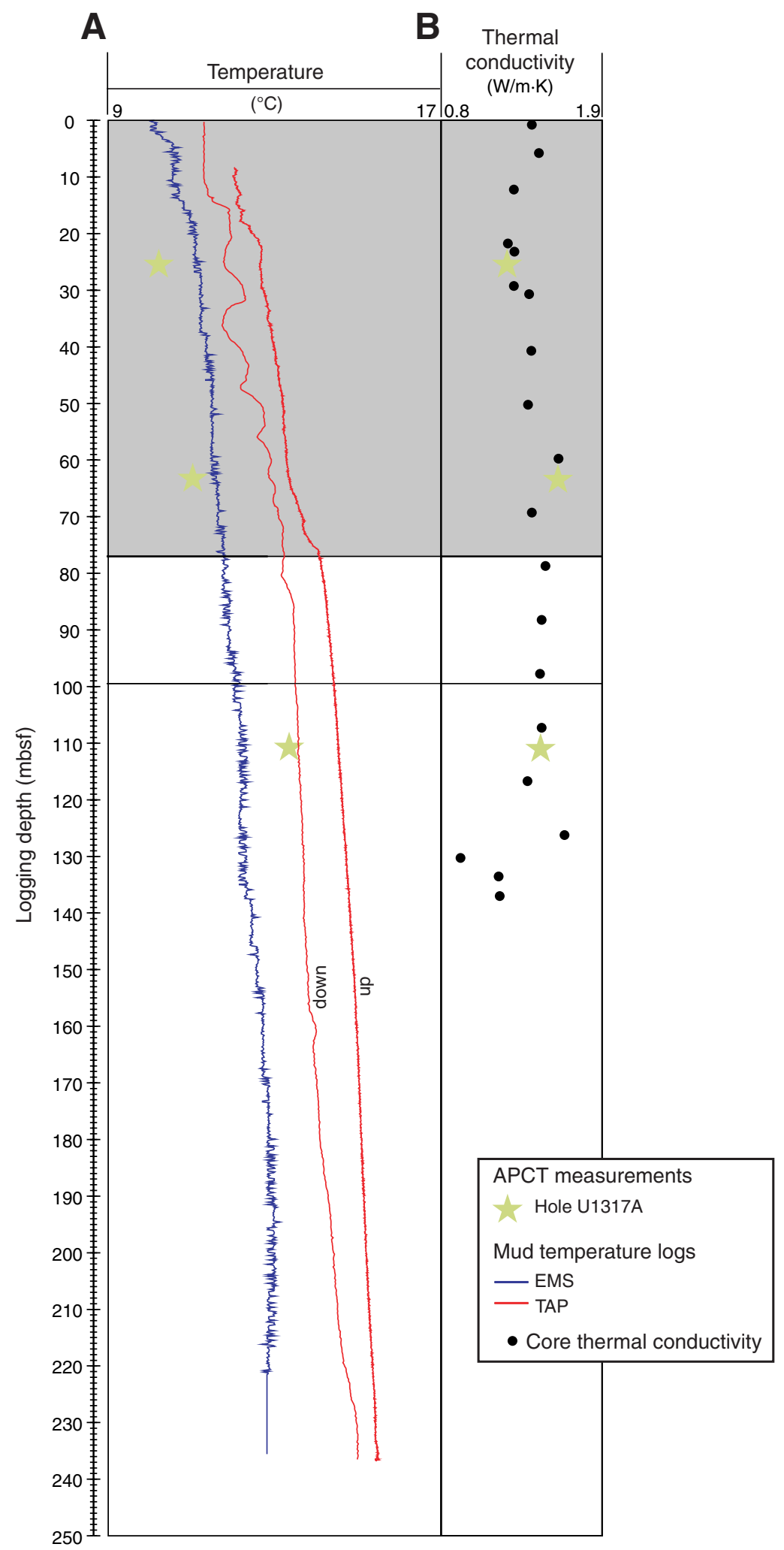


Figure F37. Dynamic normalization of FMS images between 113.4-116.4 and 180-183 mbsf to compare the difference in texture of the two distinct logging Units 1 and 2. Light yellow $=$ resistive zone, dark brown $=$ conductive zone.
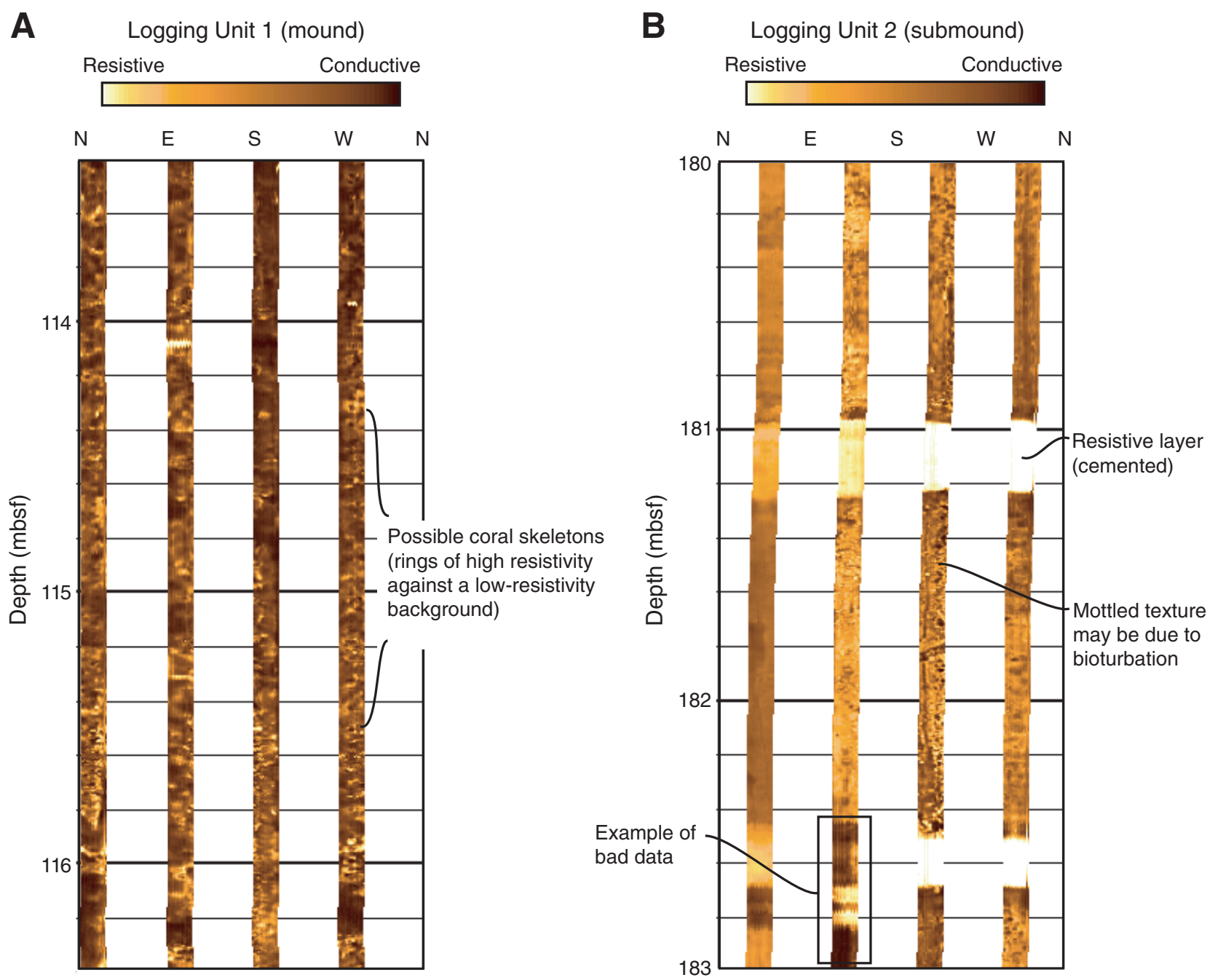
Table T1. Site U1317 coring summary. (Continued on next two pages.)

\section{Hole U1317A}

Latitude: $51^{\circ} 22.8484^{\prime} \mathrm{N}$

Longitude: $11^{\circ} 43.1083^{\prime} \mathrm{W}$

Seafloor (drill pipe measurement from rig floor; mbrf): 826.0

Distance between rig floor and sea level $(\mathrm{m}): 10.9$

Water depth (drill pipe measurement from sea level; $\mathrm{m}$ ): 815.1

Total depth (from rig floor; mbrf): 964.8

Total penetration (mbsf): 138.8

\section{Hole U1317B}

Latitude: $51^{\circ} 22.8396^{\prime} \mathrm{N}$

Longitude: $11^{\circ} 43.0920^{\prime} \mathrm{W}$

Seafloor (drill pipe measurement from rig floor; mbrf): 809.0

Distance between rig floor and sea level $(\mathrm{m}): 11.0$

Water depth (drill pipe measurement from sea level; $\mathrm{m}$ ): 798.0

Total depth (from rig floor; mbrf): 957.2

Total penetration (mbsf): 148.2

\section{Hole U1317C}

Latitude: $51^{\circ} 22.8300^{\prime} \mathrm{N}$

Longitude: $11^{\circ} 43.0759^{\prime} \mathrm{W}$

Seafloor (drill pipe measurement from rig floor; mbrf): 802.7

Distance between rig floor and sea level $(\mathrm{m}): 11.0$

Water depth (drill pipe measurement from sea level; $\mathrm{m}$ ): 791.7

Total depth (from rig floor; mbrf): 955.7

Total penetration (mbsf): 153.0

\section{Hole U1317D}

Latitude: $51^{\circ} 22.8322^{\prime} \mathrm{N}$

Longitude: $11^{\circ} 43.0918^{\prime} \mathrm{W}$

Seafloor (drill pipe measurement from rig floor; mbrf): 805.0

Distance between rig floor and sea level $(m): 11.0$

Water depth (drill pipe measurement from sea level; $m$ ): 794.0

Total depth (from rig floor; mbrf): 1075.0

Total penetration (mbsf): 270.0

\section{Hole U1317E}

Latitude: $51^{\circ} 22.7988^{\prime} \mathrm{N}$

Longitude: $11^{\circ} 43.0578^{\prime} \mathrm{W}$

Seafloor (drill pipe measurement from rig floor; mbrf): 792.2

Distance between rig floor and sea level $(\mathrm{m}): 11.0$

Water depth (drill pipe measurement from sea level; $m$ ): 781.1

Total depth (from rig floor; mbrf): 950.8

Total penetration (mbsf): 158.6

\begin{tabular}{|c|c|c|c|c|c|c|c|c|}
\hline \multirow[b]{2}{*}{ Core } & \multirow{2}{*}{$\begin{array}{c}\text { Date } \\
\text { (May 2005) }\end{array}$} & \multirow{2}{*}{ Local time } & \multicolumn{2}{|c|}{ Depth (mbsf) } & \multicolumn{2}{|c|}{ Length $(\mathrm{m})$} & \multirow{2}{*}{$\begin{array}{c}\text { Recovery } \\
\text { (\%) }\end{array}$} & \multirow[b]{2}{*}{ Comment } \\
\hline & & & Top & Bottom & Cored & Recovered & & \\
\hline \multicolumn{9}{|c|}{ 307-U1317A- } \\
\hline 1-H & 2 & 2345 & 0.0 & 6.5 & 6.5 & 6.55 & 100.77 & \\
\hline $2-\mathrm{H}$ & 3 & 0015 & 6.5 & 16.0 & 9.5 & 9.47 & 99.68 & \\
\hline $3-\mathrm{H}$ & 3 & 0130 & 16.0 & 25.5 & 9.5 & 10.11 & 106.42 & Tensor 1 started at $0045 \mathrm{hr}$; Adara \\
\hline $4-\mathrm{H}$ & 3 & 0220 & 25.5 & 35.0 & 9.5 & 9.96 & 104.84 & \\
\hline $5-\mathrm{H}$ & 3 & 0305 & 35.0 & 44.5 & 9.5 & 10.07 & 106.00 & \\
\hline $6-\mathrm{H}$ & 3 & 0345 & 44.5 & 54.0 & 9.5 & 10.05 & 105.79 & \\
\hline $7-\mathrm{H}$ & 3 & 0440 & 54.0 & 63.5 & 9.5 & 10.36 & 109.05 & \\
\hline $8-\mathrm{H}$ & 3 & 0530 & 63.5 & 73.0 & 9.5 & 9.32 & 98.11 & \\
\hline $9-\mathrm{H}$ & 3 & 0615 & 73.0 & 82.5 & 9.5 & 10.02 & 105.47 & \\
\hline $10-\mathrm{H}$ & 3 & 0720 & 82.5 & 92.0 & 9.5 & 10.35 & 108.95 & \\
\hline $11-\mathrm{H}$ & 3 & 0800 & 92.0 & 101.5 & 9.5 & 9.85 & 103.68 & \\
\hline $12-\mathrm{H}$ & 3 & 0930 & 101.5 & 111.0 & 9.5 & 9.22 & 97.05 & Drill over core barrel \\
\hline $13-\mathrm{H}$ & 3 & 1010 & 111.0 & 120.5 & 9.5 & 10.23 & 107.68 & \\
\hline $14-\mathrm{H}$ & 3 & 1055 & 120.5 & 130.0 & 9.5 & 10.25 & 107.89 & \\
\hline $15-\mathrm{H}$ & 3 & 1145 & 130.0 & 130.5 & 0.5 & 0.81 & 162.00 & \\
\hline $16-\mathrm{H}$ & 3 & 1240 & 130.5 & 130.8 & 0.3 & 0.28 & 93.33 & \\
\hline $17-x$ & 3 & 1430 & 130.8 & 136.3 & 5.5 & 3.39 & 61.64 & \\
\hline \multirow{2}{*}{$18-X$} & 3 & 1710 & 136.3 & 138.8 & 2.5 & 1.65 & 66.00 & \\
\hline & & & & Core totals: & 138.8 & 141.94 & 102.26 & \\
\hline
\end{tabular}


Table T1 (continued).

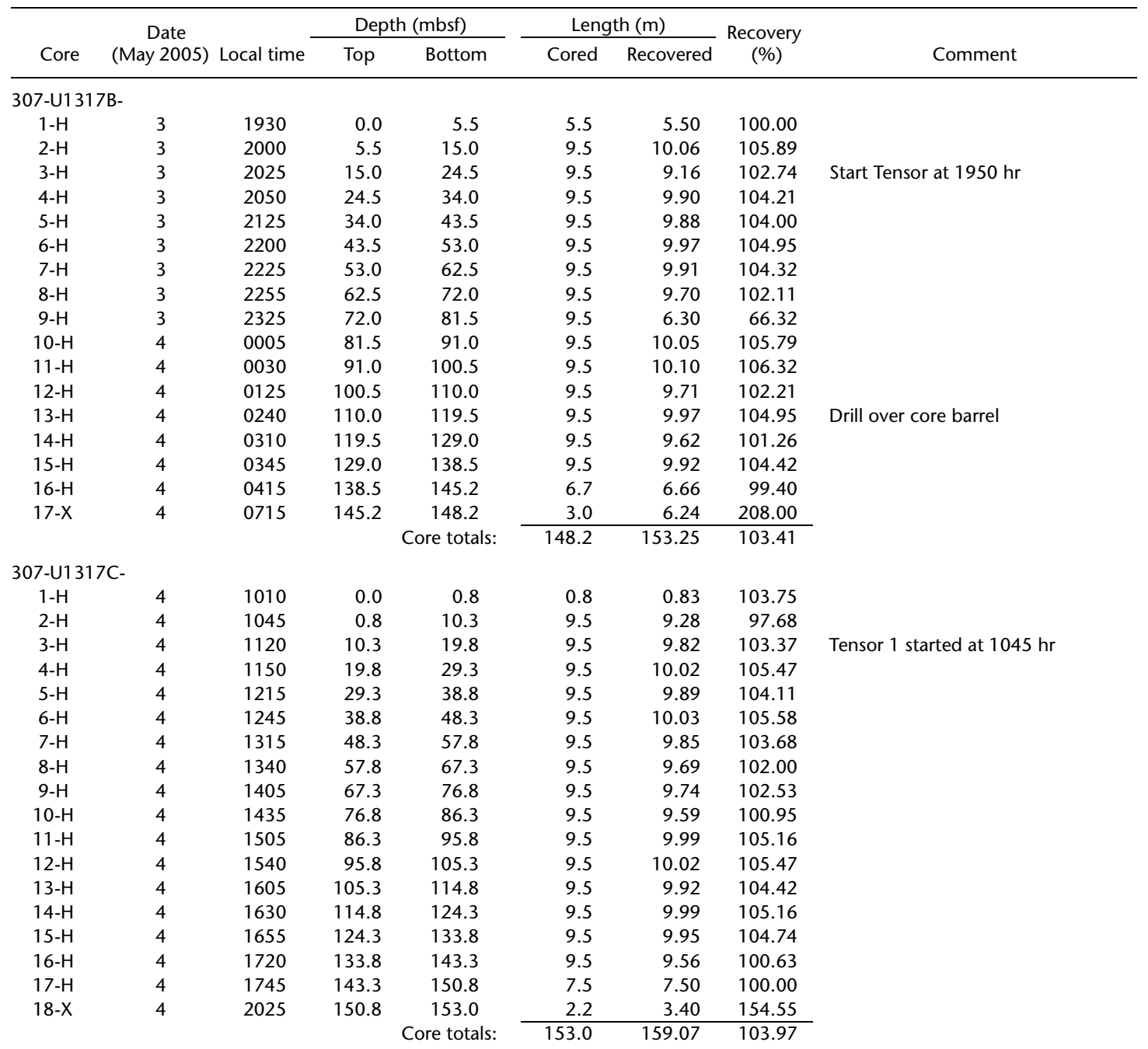

307-U1317D-

$\begin{array}{cc}1-\mathrm{R} & 5 \\ 2-\mathrm{R} & 5 \\ 3-\mathrm{R} & 5 \\ 4-\mathrm{R} & 5 \\ 5-\mathrm{R} & 5 \\ 6-\mathrm{R} & 5 \\ 7-\mathrm{R} & 5 \\ 8-\mathrm{R} & 5 \\ 9-\mathrm{R} & 5 \\ 10-\mathrm{R} & 5 \\ 11-\mathrm{R} & 5 \\ 12-\mathrm{R} & 5 \\ 13-\mathrm{R} & 5 \\ 14-\mathrm{R} & 5 \\ 15-\mathrm{R} & 5 \\ 16-\mathrm{R} & 6 \\ 17-\mathrm{R} & 6 \\ 18-\mathrm{R} & 6\end{array}$

\begin{tabular}{cccrrr}
$* * * * *$ Drilled from 0.0 to 110.0 mbsf**** & & & \\
0710 & 110.0 & 116.9 & 6.9 & 0.11 & 1.59 \\
0745 & 116.9 & 126.6 & 9.7 & 0.09 & 0.93 \\
0815 & 126.6 & 136.2 & 9.6 & 4.35 & 45.31 \\
0840 & 136.2 & 145.8 & 9.6 & 1.78 & 18.54 \\
0930 & 145.8 & 150.4 & 4.6 & 3.13 & 68.04 \\
1030 & 150.4 & 155.4 & 5.0 & 5.24 & 104.80 \\
1205 & 155.4 & 165.1 & 9.7 & 8.26 & 85.15 \\
1305 & 165.1 & 174.7 & 9.6 & 8.86 & 92.29 \\
1430 & 174.7 & 184.3 & 9.6 & 9.48 & 98.75 \\
1605 & 184.3 & 193.9 & 9.6 & 4.77 & 49.69 \\
1715 & 193.9 & 203.5 & 9.6 & 4.59 & 47.81 \\
1855 & 203.5 & 213.1 & 9.6 & 4.94 & 51.46 \\
2055 & 213.1 & 222.7 & 9.6 & 9.88 & 102.92 \\
2215 & 222.7 & 232.3 & 9.6 & 9.15 & 95.31 \\
2340 & 232.3 & 241.9 & 9.6 & 1.90 & 19.79 \\
0135 & 241.9 & 251.5 & 9.6 & 9.94 & 103.54 \\
0250 & 251.5 & 261.2 & 9.7 & 7.13 & 73.51 \\
0420 & 261.2 & 270.0 & 8.8 & 7.92 & 90.00 \\
\hline & & Core totals: & 160.0 & 101.52 & 63.45
\end{tabular}


Table T1 (continued).

\begin{tabular}{|c|c|c|c|c|c|c|c|c|}
\hline \multirow[b]{2}{*}{ Core } & \multirow{2}{*}{$\begin{array}{c}\text { Date } \\
\text { (May 2005) }\end{array}$} & \multirow{2}{*}{ Local time } & \multicolumn{2}{|c|}{ Depth (mbsf) } & \multicolumn{2}{|c|}{ Length $(\mathrm{m})$} & \multirow{2}{*}{$\begin{array}{l}\text { Recovery } \\
\text { (\%) }\end{array}$} & \multirow[b]{2}{*}{ Comment } \\
\hline & & & Top & Bottom & Cored & Recovered & & \\
\hline \multicolumn{9}{|c|}{ 307-U1317E- } \\
\hline $1-\mathrm{H}$ & 11 & 1440 & 0.0 & 6.7 & 6.7 & 6.70 & 100.00 & \\
\hline $2-\mathrm{H}$ & 11 & 1500 & 6.7 & 16.2 & 9.5 & 9.97 & 104.95 & \\
\hline $3-\mathrm{H}$ & 11 & 1530 & 16.2 & 25.7 & 9.5 & 9.77 & 102.84 & \\
\hline $4-\mathrm{H}$ & 11 & 1600 & 25.7 & 35.2 & 9.5 & 9.90 & 104.21 & \\
\hline $5-\mathrm{H}$ & 11 & 1625 & 35.2 & 44.7 & 9.5 & 9.87 & 103.89 & \\
\hline $6-\mathrm{H}$ & 11 & 1650 & 44.7 & 54.2 & 9.5 & 9.40 & 98.95 & \\
\hline $7-\mathrm{H}$ & 11 & 1720 & 54.2 & 63.7 & 9.5 & 9.68 & 101.89 & \\
\hline $8-\mathrm{H}$ & 11 & 1745 & 63.7 & 73.2 & 9.5 & 9.47 & 99.68 & \\
\hline $9-\mathrm{H}$ & 11 & 1810 & 73.2 & 82.7 & 9.5 & 9.92 & 104.42 & \\
\hline $10-\mathrm{H}$ & 11 & 1840 & 82.7 & 92.2 & 9.5 & 9.76 & 102.74 & \\
\hline $11-\mathrm{H}$ & 11 & 1905 & 92.2 & 101.7 & 9.5 & 9.80 & 103.16 & \\
\hline $12-\mathrm{H}$ & 11 & 1940 & 101.7 & 111.2 & 9.5 & 9.96 & 104.84 & \\
\hline $13-\mathrm{H}$ & 11 & 2005 & 111.2 & 120.7 & 9.5 & 9.84 & 103.58 & \\
\hline $14-\mathrm{H}$ & 11 & 2035 & 120.7 & 130.2 & 9.5 & 10.04 & 105.68 & \\
\hline $15-\mathrm{H}$ & 11 & 2105 & 130.2 & 139.7 & 9.5 & 9.98 & 105.05 & \\
\hline $16-\mathrm{H}$ & 11 & 2155 & 139.7 & 149.2 & 9.5 & 10.04 & 105.68 & \\
\hline $17-\mathrm{H}$ & 11 & 2245 & 149.2 & 155.3 & 6.1 & 6.10 & 100.00 & Drill over core barrel \\
\hline \multirow[t]{2}{*}{$18-\mathrm{H}$} & 11 & 2330 & 155.3 & 158.6 & 3.3 & 3.28 & 99.39 & \\
\hline & & & & Core totals: & 158.6 & 163.48 & 103.08 & \\
\hline
\end{tabular}

Table T2. Calcareous nannofossil biostratigraphic data considered for splice correlation, Hole U1317A.

\begin{tabular}{|c|c|}
\hline Datum & Age (Ma) \\
\hline FAD Emiliania huxleyi & 0.26 \\
\hline LAD Pseudoemilinia lacunosa & 0.46 \\
\hline ACM small Gephyrocapsa & 0.96 \\
\hline LAD Helicosphaera sellii & 1.22 \\
\hline LAD Calcidiscus macintyrei & 1.59 \\
\hline LAD Sphenolithus spp. & 3.60 \\
\hline LAD Reticulofenestra pseudoumbilica & 3.60 \\
\hline LAD Discoaster bollii & 9.10 \\
\hline FAD Cyclicargolithus floridanus & 13.24 \\
\hline LAD Sphenolithus heteromorphus & 13.60 \\
\hline LAD Helicosphaera ampliaperta & 15.60 \\
\hline LAD Discoaster deflandrei & 16.24 \\
\hline Discoaster exilis & Zone CN3-CN4 \\
\hline
\end{tabular}

Note: $F A D=$ first appearance datum, $L A D=$ last appearance datum, $A C M=$ acme zone.

Table T3. Planktonic foraminifer biostratigraphic data used for splice correlation, Hole U1317A.

\begin{tabular}{llrl}
\hline \multicolumn{1}{c}{ Datum } & Core, section & $\begin{array}{r}\text { Depth } \\
(\mathrm{mbsf})\end{array}$ & $\begin{array}{l}\text { Age } \\
(\mathrm{Ma})\end{array}$ \\
\hline & 307-U1317A- & & \\
LAD Globorotalia tosaensis & 7H-CC & 63.7 & 0.65 \\
LAD Globorotalia puncticulata & 13H-CC & 120.9 & 2.41 \\
FAD Globorotalia inflata & 18X-CC & 137.5 & 3.20 \\
\hline
\end{tabular}

Note: $F A D=$ first appearance datum, LAD = last appearance datum. 
Table T4. Nannofossil age assignment and preservation, Hole U1317A.

\begin{tabular}{|c|c|c|c|}
\hline $\begin{array}{l}\text { Core, section, } \\
\text { interval }(\mathrm{cm})\end{array}$ & $\begin{array}{l}\text { Depth } \\
\text { (mbsf) }\end{array}$ & Reworking/Preservation & Nannofossil age \\
\hline \multicolumn{4}{|l|}{ 307-U1317A- } \\
\hline $1 \mathrm{H}-\mathrm{CC}$ & 6.4 & & Middle-early Pleistocene (0.46-1.59 Ma) \\
\hline $2 \mathrm{H}-\mathrm{CC}$ & 15.8 & No reworking & Middle-early Pleistocene (0.46-1.59 Ma) \\
\hline $3 \mathrm{H}-\mathrm{CC}$ & 25.6 & Poor preservation & - \\
\hline $4 \mathrm{H}-\mathrm{CC}$ & 35.2 & Poor preservation & Middle-early Pleistocene (0.46-1.59 Ma) \\
\hline $5 \mathrm{H}-\mathrm{CC}$ & 44.7 & Reworking from Cretaceous & - \\
\hline $6 \mathrm{H}-\mathrm{CC}$ & 54.3 & & Middle-early Pleistocene (0.46-1.59 Ma) \\
\hline $7 \mathrm{H}-\mathrm{CC}$ & 63.7 & Poor preservation & - \\
\hline $8 \mathrm{H}-\mathrm{CC}$ & 72.5 & Poor preservation & - \\
\hline $9 \mathrm{H}-\mathrm{CC}$ & 82.7 & & Early Pleistocene (1.59-1.95 Ma) \\
\hline $10 \mathrm{H}-\mathrm{CC}$ & 92.3 & & - \\
\hline $11 \mathrm{H}-\mathrm{CC}$ & 101.7 & & Early Pleistocene (1.59-1.95 Ma) \\
\hline $12 \mathrm{H}-\mathrm{CC}$ & 110.5 & & - \\
\hline $13 \mathrm{H}-\mathrm{CC}$ & 120.9 & Reworking from Cretaceous & - \\
\hline $14 \mathrm{H}-5,139-140$ & 128.4 & & Early Pleistocene (1.59-1.95 Ma) \\
\hline $16 \mathrm{H}-\mathrm{CC}$ & 130.5 & & $>15.6 \mathrm{Ma}$ \\
\hline
\end{tabular}

Note: $-=$ undetermined . 
Table T5. Interstitial water data, Holes U1317A, U1317D, and U1317E. (See table notes. Continued on next page.)

\begin{tabular}{|c|c|c|c|c|c|c|c|c|c|c|c|c|c|c|c|c|c|c|}
\hline \multirow[b]{2}{*}{$\begin{array}{l}\text { Core, section, } \\
\text { interval }(\mathrm{cm})\end{array}$} & \multirow[b]{2}{*}{$\begin{array}{l}\text { Depth } \\
\text { (mbsf) }\end{array}$} & \multirow[b]{2}{*}{$\mathrm{pH}$} & \multirow[b]{2}{*}{$\begin{array}{c}\text { Alkalinity } \\
(\mathrm{mM})\end{array}$} & \multirow{2}{*}{\multicolumn{7}{|c|}{ Trace elements $(\mu \mathrm{M})$}} & \multirow{2}{*}{\multicolumn{2}{|c|}{ Cations (mM) }} & \multirow[b]{2}{*}{$\begin{array}{c}\text { DIC } \\
(\mathrm{mM})\end{array}$} & \multirow[b]{2}{*}{$\begin{array}{l}\mathrm{SO}_{4} \\
(\mathrm{mM})\end{array}$} & \multicolumn{2}{|c|}{ Chlorinity } & \multirow[b]{2}{*}{$\begin{array}{l}\mathrm{NH}_{4}^{+} \\
(\mu \mathrm{M})\end{array}$} & \multirow[b]{2}{*}{$\mathrm{Mg} / \mathrm{Ca}$} \\
\hline & & & & & & & & & & $\mathrm{Sr}$ & & & & & $\begin{array}{c}\mathrm{IC} \\
(\mathrm{mM})\end{array}$ & $\begin{array}{c}\text { titr. } \\
(\mathrm{mM})\end{array}$ & & \\
\hline \multicolumn{19}{|l|}{ 307-U1317A- } \\
\hline $1 \mathrm{H}-1,140-150$ & 1.40 & 7.69 & 3.62 & 547 & 0.63 & 39 & 39.8 & 3 & 521 & 212 & 11.1 & 51.3 & 3.01 & 27.3 & ND & 567 & 30.5 & 4.87 \\
\hline $1 \mathrm{H}-3,190-200$ & 4.90 & 7.64 & 4.16 & 546 & 0.24 & 4 & 45.5 & 0 & 448 & 357 & 11.3 & 50.9 & 3.83 & 25.8 & ND & 568 & 121 & 4.66 \\
\hline $2 \mathrm{H}-1,140-150$ & 7.90 & 7.50 & 4.38 & 530 & 0.26 & 1 & 44.7 & 0 & 358 & 404 & 11.2 & 50.3 & 4.23 & 26.0 & ND & 568 & 160 & 4.60 \\
\hline $2 \mathrm{H}-3,190-200$ & 11.40 & 7.52 & 4.88 & 591 & 0.25 & 0 & 52.2 & 0 & 414 & 501 & 11.3 & 48.7 & 4.64 & 25.2 & ND & 570 & 232 & 4.55 \\
\hline $3 \mathrm{H}-1,140-150$ & 17.40 & 7.53 & 6.59 & 690 & 0.30 & 0 & 64.3 & 0 & 685 & 666 & 11.8 & 47.3 & 6.51 & 23.6 & ND & 570 & 386 & 4.19 \\
\hline $3 \mathrm{H}-3,190-200$ & 20.90 & 7.45 & 7.85 & 688 & 0.26 & 5 & 66.3 & 0 & 585 & 657 & 11.3 & 45.8 & 6.26 & 22.8 & ND & 571 & 478 & 4.07 \\
\hline $4 \mathrm{H}-1,140-150$ & 26.90 & 7.34 & 7.70 & 646 & 0.19 & 2 & 68.7 & 0 & 466 & 627 & 11.4 & 44.7 & 7.69 & 21.8 & ND & 571 & 557 & 3.92 \\
\hline $4 \mathrm{H}-4,140-150$ & 31.40 & 7.36 & 8.28 & 819 & 0.10 & 3 & 85.9 & 0 & 656 & 725 & 11.8 & 44.8 & 9.97 & 21.0 & ND & 571 & 642 & 3.86 \\
\hline $5 \mathrm{H}-1,140-150$ & 36.40 & 7.36 & ND & 833 & 0.23 & 0 & 90.8 & 0 & 701 & 767 & 11.9 & 43.6 & 8.79 & 20.9 & ND & 567 & 713 & 3.76 \\
\hline $5 \mathrm{H}-3,190-200$ & 39.90 & 7.26 & 9.20 & 917 & 0.28 & 0 & 99.3 & 0 & 783 & 848 & 11.5 & 42.6 & 9.43 & 20.5 & ND & 567 & 730 & 3.71 \\
\hline $6 \mathrm{H}-1,140-150$ & 45.90 & 7.33 & 8.66 & 855 & 0.13 & 4 & 102 & 0 & 446 & 755 & 11.2 & 42.7 & 8.89 & 20.0 & ND & 566 & 801 & 3.92 \\
\hline $6 \mathrm{H}-3,190-200$ & 49.40 & 7.31 & 9.73 & 885 & 0.27 & 4 & 104 & 0 & 455 & 812 & 11.4 & 42.0 & 10.1 & 19.8 & ND & ND & 842 & 3.76 \\
\hline 7H-1, $140-150$ & 55.40 & 7.12 & 9.69 & 919 & 0.11 & 1 & 120 & 0 & 470 & 797 & 11.2 & 42.5 & 9.97 & 19.3 & ND & 570 & 922 & 3.82 \\
\hline 7H-3, 190-200 & 58.90 & 7.24 & 10.9 & 955 & 0.16 & 3 & 119 & 0 & 562 & 827 & 13.6 & 40.9 & 12.9 & 18.0 & ND & 569 & 1020 & 3.63 \\
\hline $8 \mathrm{H}-1,140-150$ & 64.90 & 7.36 & 11.6 & 951 & 0.14 & 0 & 128 & 0 & 702 & 887 & 11.3 & 39.6 & 13.7 & 16.7 & ND & 569 & 1044 & 3.65 \\
\hline $8 \mathrm{H}-3,190-200$ & 68.40 & 7.25 & 11.7 & 1046 & 0.15 & 0 & 149 & 0 & 667 & 1050 & 10.8 & 38.9 & 14.5 & 15.5 & ND & 570 & 1139 & 3.73 \\
\hline $9 \mathrm{H}-1,140-150$ & 74.40 & 7.20 & 12.0 & 1089 & 0.11 & 0 & 158 & 0 & 627 & 1089 & 10.4 & 37.8 & 14.7 & 14.3 & ND & 564 & 1197 & 3.67 \\
\hline $9 \mathrm{H}-3,190-200$ & 77.90 & 7.24 & 12.4 & 1129 & 0.32 & 0 & 173 & 0 & 647 & 1237 & 11.5 & 37.0 & 14.6 & 13.3 & ND & 570 & 994 & 3.79 \\
\hline $10 \mathrm{H}-1,140-150$ & 83.90 & 7.26 & 12.5 & 1123 & 0.33 & 0 & 180 & 0 & 568 & 1290 & 9.80 & 37.1 & 15.3 & 12.8 & ND & 568 & 1463 & 3.91 \\
\hline $10 \mathrm{H}-3,190-200$ & 87.40 & 7.31 & 14.3 & 1273 & 0.45 & 4 & 197 & 0 & 608 & 1497 & 10.3 & 36.4 & 17.4 & 11.8 & ND & 568 & 1406 & 3.71 \\
\hline $11 \mathrm{H}-1,140-150$ & 93.40 & 7.24 & 13.5 & 1137 & 0.48 & 0 & 193 & 0 & 479 & 1532 & 9.47 & 35.3 & 16.4 & 12.0 & ND & 566 & 1465 & 3.90 \\
\hline $11 \mathrm{H}-3,190-200$ & 96.90 & 7.11 & 14.1 & 1261 & 0.40 & 0 & 214 & 0 & 613 & 1696 & 9.16 & 35.0 & 17.6 & 10.2 & ND & 571 & 1655 & 3.95 \\
\hline $12 \mathrm{H}-1,140-150$ & 102.90 & 7.24 & 13.0 & 1078 & 0.37 & 0 & 186 & 0 & 558 & 1519 & 9.19 & 36.9 & 15.3 & 11.6 & ND & 575 & 1468 & 4.07 \\
\hline $12 \mathrm{H}-3,190-200$ & 106.40 & 7.17 & 15.0 & 1281 & 0.54 & 0 & 225 & 0 & 754 & 2000 & 9.57 & 34.3 & 19.2 & 8.66 & ND & 575 & 1821 & 3.76 \\
\hline $13 \mathrm{H}-1,140-150$ & 112.40 & 7.20 & 15.5 & 1347 & 0.76 & 0 & 239 & 0 & 719 & 2201 & 9.09 & 34.2 & ND & 8.24 & ND & 573 & 1722 & 3.77 \\
\hline $13 \mathrm{H}-3,190-200$ & 115.90 & 7.26 & 15.2 & 1288 & 0.86 & 0 & 241 & 0 & 624 & 2094 & 8.70 & 33.9 & 19.0 & 7.76 & ND & 575 & 1837 & 3.94 \\
\hline $14 \mathrm{H}-1,140-150$ & 121.90 & 7.28 & 16.0 & 1374 & 1.06 & 0 & 253 & 1 & 660 & 2317 & 9.35 & 34.9 & 20.3 & 8.70 & ND & 574 & 1670 & 3.76 \\
\hline $14 \mathrm{H}-3,190-200$ & 125.40 & 7.35 & 16.0 & 1417 & 1.09 & 0 & 273 & 0 & 721 & 2257 & 9.05 & 34.4 & 20.2 & 6.92 & ND & 573 & 1896 & 3.69 \\
\hline $17 X-1,190-200$ & 132.70 & ND & ND & 1228 & 1.49 & 11 & 270 & 0 & 939 & 1909 & ND & ND & ND & 7.23 & ND & 568 & ND & 3.89 \\
\hline $18 \mathrm{X}-1,30-50$ & 136.60 & 7.16 & 15.7 & 1330 & 1.64 & 0 & 278 & 0 & 1032 & 1997 & 9.46 & 33.9 & 19.8 & 5.86 & ND & 572 & 1863 & 3.56 \\
\hline $18 X-1,30-50$ & 136.60 & ND & ND & 1288 & 1.67 & 0 & 284 & 0 & 1010 & 1995 & 9.77 & 34.7 & ND & ND & ND & ND & 1839 & 3.55 \\
\hline \multicolumn{19}{|l|}{ 307-U1317D- } \\
\hline $3 R-2,185-200$ & 129.95 & 7.21 & 16.9 & 1182 & 1.23 & 6 & 231 & 0 & 618 & 1941 & 8.67 & 33.8 & 18.2 & 6.46 & ND & 570 & 1842 & 3.85 \\
\hline $4 \mathrm{R}-2,0-10$ & 137.20 & 7.21 & 16.9 & 1186 & 1.34 & 0 & 236 & 0 & 585 & 1902 & 8.73 & 33.2 & 17.8 & 5.43 & ND & 571 & 1915 & 3.82 \\
\hline $5 \mathrm{R}-1,198-213$ & 147.78 & 7.15 & 16.3 & 1165 & 1.66 & 6 & 236 & 0 & 840 & 1682 & 8.95 & 32.9 & 16.1 & 3.85 & ND & 575 & 2045 & 3.72 \\
\hline $6 \mathrm{R}-1,185-200$ & 152.25 & 7.45 & 14.4 & 1010 & 1.97 & 1 & 230 & 0 & 849 & 1410 & 9.65 & 34.4 & 13.8 & 6.24 & ND & ND & 1930 & ND \\
\hline $7 \mathrm{R}-2,185-200$ & 158.75 & 7.24 & 19.0 & 1244 & 2.05 & 4 & 267 & 0 & 908 & 1552 & 8.48 & 28.6 & ND & 2.94 & ND & 574 & 2003 & 3.48 \\
\hline $7 R-4,135-150$ & 161.75 & 7.24 & 16.2 & 1244 & 2.50 & 8 & 264 & 0 & 923 & 1471 & 9.66 & 33.6 & 17.4 & 3.65 & ND & 575 & 2003 & 3.42 \\
\hline $8 \mathrm{R}-2,182-197$ & 168.42 & ND & ND & 1326 & 2.26 & 1 & 271 & 0 & 730 & 1283 & 7.73 & 25.4 & 15.9 & 1.77 & ND & ND & 2393 & 3.41 \\
\hline $8 R-5,93-115$ & 172.50 & 7.21 & 17.5 & 1470 & 2.60 & 2 & 284 & 0 & 876 & 1340 & 10.6 & 31.7 & 19.1 & 1.86 & ND & 572 & 2409 & 3.13 \\
\hline $9 \mathrm{R}-1,185-200$ & 176.55 & ND & ND & 1355 & 2.85 & 1 & 279 & 0 & 792 & 1205 & 10.2 & 31.6 & 14.5 & 2.15 & ND & ND & 2352 & 3.30 \\
\hline $9 R-5,135-150$ & 182.55 & ND & ND & 1361 & 3.72 & 1 & 287 & 0 & 750 & 1162 & 10.1 & 32.1 & ND & 2.34 & ND & ND & 2466 & ND \\
\hline 10R-2, 124-145 & 187.54 & 7.27 & 16.7 & 1445 & 5.38 & 2 & 298 & 0 & 834 & 1196 & 11.2 & 32.3 & 15.5 & 0.98 & ND & 573 & 2347 & 3.11 \\
\hline $11 \mathrm{R}-2,180-200$ & 197.20 & 7.29 & 15.6 & 1470 & 6.79 & 0 & 312 & 0 & 744 & 1139 & 10.5 & 32.1 & 15.4 & 0.67 & ND & 574 & 2425 & 3.01 \\
\hline $12 \mathrm{R}-3,180-200$ & 207.80 & 7.18 & 16.3 & 1732 & 7.62 & 0 & 324 & 0 & 743 & 1136 & 10.9 & 32.0 & 16.5 & 0.43 & ND & 572 & 2575 & 2.97 \\
\hline $13 R-5,180-200$ & 220.90 & 7.25 & 15.3 & 1920 & 8.41 & 17 & 339 & 0 & 814 & 1152 & 11.2 & 30.9 & 16.0 & ND & ND & 574 & 2638 & 2.83 \\
\hline $14 \mathrm{R}-3,180-200$ & 227.50 & 7.32 & 14.4 & 1812 & 8.80 & 0 & 331 & 0 & 797 & 1122 & 11.6 & 31.9 & 12.1 & 1.32 & ND & 577 & 2518 & 2.83 \\
\hline 16R-3, $180-200$ & 24670 & 7.24 & 131 & 1970 & 9.66 & 0 & 346 & 0 & 764 & 1170 & 12.0 & 316 & ND & 173 & $\mathrm{ND}$ & 579 & 2570 & 265 \\
\hline
\end{tabular}




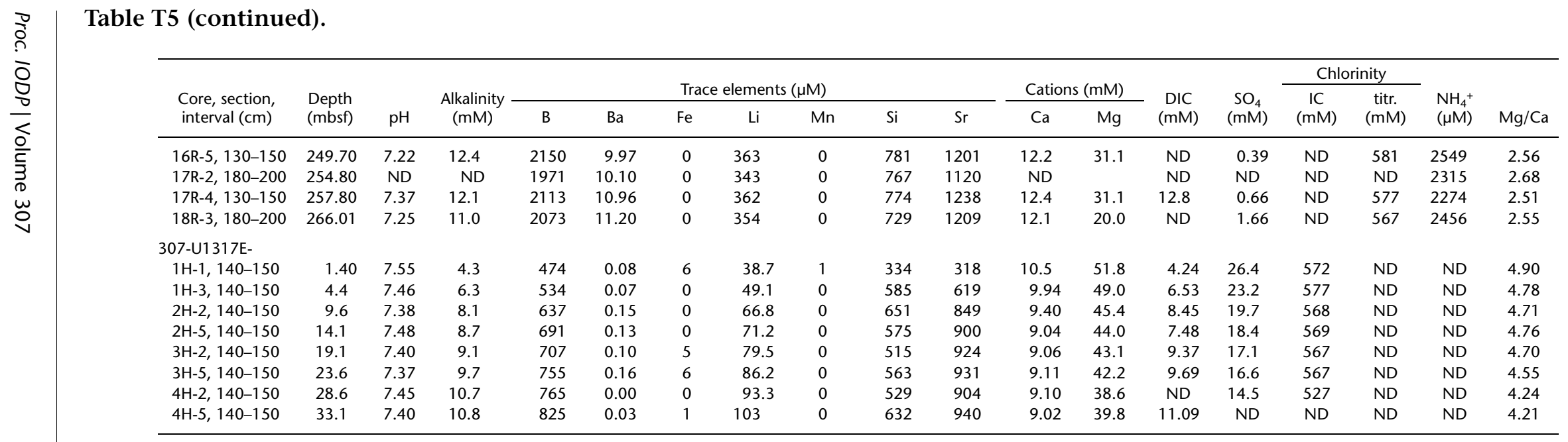

Notes: $\mathrm{DIC}=$ dissolved inorganic carbon, $\mathrm{IC}=$ ion chromatography, titr. = titration. ND $=$ not determined. 
Table T6. Headspace gas, Holes U1317A and U1317D.

\begin{tabular}{|c|c|c|c|c|c|c|c|}
\hline Core, section & $\begin{array}{l}\text { Depth } \\
\text { (mbsf) }\end{array}$ & $\begin{array}{l}\text { Safety } \mathrm{CH}_{4} \\
\quad(\mathrm{ppm})\end{array}$ & $\begin{array}{l}\text { Safety } \mathrm{C}_{2} \mathrm{H}_{6} \\
(\mathrm{ppm})\end{array}$ & $\begin{array}{l}\mathrm{C}_{2} / \mathrm{C}_{1} \\
\text { ratio }\end{array}$ & $\begin{array}{c}\text { Dissolved } \\
\text { methane }(\mu \mathrm{M})\end{array}$ & $\begin{array}{l}\text { Adsorbed methane } \\
(\mu \mathrm{mol} / \mathrm{g})\end{array}$ & $\begin{array}{c}\text { Dissolved } \\
\text { ethane }(\mu \mathrm{M})\end{array}$ \\
\hline \multicolumn{8}{|l|}{ 307-U1317A- } \\
\hline $1 \mathrm{H}-4$ & 5 & 1.90 & $\mathrm{BDL}$ & $\mathrm{BDL}$ & 0.087 & $\mathrm{BDL}$ & $\mathrm{BDL}$ \\
\hline $2 \mathrm{H}-4$ & 11.5 & 2.00 & $\mathrm{BDL}$ & $\mathrm{BDL}$ & 0.100 & $\mathrm{BDL}$ & $\mathrm{BDL}$ \\
\hline $3 \mathrm{H}-4$ & 21 & 1.80 & $\mathrm{BDL}$ & $\mathrm{BDL}$ & 0.049 & $\mathrm{BDL}$ & $\mathrm{BDL}$ \\
\hline $4 \mathrm{H}-5$ & 32 & 2.10 & $\mathrm{BDL}$ & $\mathrm{BDL}$ & 0.178 & $\mathrm{BDL}$ & $\mathrm{BDL}$ \\
\hline $6 \mathrm{H}-4$ & 49.5 & 2.10 & $\mathrm{BDL}$ & BDL & 0.173 & $\mathrm{BDL}$ & $\mathrm{BDL}$ \\
\hline $7 \mathrm{H}-4$ & 59 & 2.00 & $\mathrm{BDL}$ & BDL & 0.150 & $\mathrm{BDL}$ & $\mathrm{BDL}$ \\
\hline $8 \mathrm{H}-4$ & 68.5 & 1.90 & $\mathrm{BDL}$ & BDL & 0.127 & $\mathrm{BDL}$ & BDL \\
\hline $9 \mathrm{H}-4$ & 78 & 1.90 & $\mathrm{BDL}$ & BDL & 0.097 & $\mathrm{BDL}$ & $\mathrm{BDL}$ \\
\hline $10 \mathrm{H}-4$ & 87.5 & 2.10 & $\mathrm{BDL}$ & $\mathrm{BDL}$ & 0.222 & $\mathrm{BDL}$ & $\mathrm{BDL}$ \\
\hline $11 \mathrm{H}-4$ & 97 & 2.00 & $\mathrm{BDL}$ & $\mathrm{BDL}$ & 0.365 & $\mathrm{BDL}$ & $\mathrm{BDL}$ \\
\hline $12 \mathrm{H}-4$ & 106.5 & 2.30 & BDL & $\mathrm{BDL}$ & 0.300 & $\mathrm{BDL}$ & $\mathrm{BDL}$ \\
\hline $13 \mathrm{H}-4$ & 116 & 2.10 & $\mathrm{BDL}$ & $\mathrm{BDL}$ & 0.258 & $\mathrm{BDL}$ & $\mathrm{BDL}$ \\
\hline $14 \mathrm{H}-4$ & 125.5 & 2.40 & BDL & $\mathrm{BDL}$ & 0.667 & $\mathrm{BDL}$ & $\mathrm{BDL}$ \\
\hline $17 X-2$ & 132.8 & 308 & 1.20 & $\mathrm{BDL}$ & 105 & 0.02 & 0.41 \\
\hline $18 X-1$ & 136.8 & 576 & 1.90 & $\mathrm{BDL}$ & 338 & $\mathrm{BDL}$ & 1.12 \\
\hline \multicolumn{8}{|l|}{ 307-U1317D- } \\
\hline $3 R-3$ & 130.10 & 2.10 & $\mathrm{BDL}$ & $\mathrm{BDL}$ & 0.286 & 0.01 & $\mathrm{BDL}$ \\
\hline $4 \mathrm{R}-2$ & 137.30 & 2.50 & BDL & ND & 0.461 & ND & ND \\
\hline $5 R-1$ & 147.73 & 220 & BDL & ND & 87.0 & ND & ND \\
\hline $6 \mathrm{R}-1$ & 152.20 & 528 & 1.50 & $2.85 \mathrm{E}-03$ & 284 & 0.07 & 0.81 \\
\hline 7R-2 & 158.70 & 1190 & 3.60 & $3.03 E-03$ & 690 & $\mathrm{BDL}$ & 2.09 \\
\hline $8 R-2$ & 168.37 & 3010 & 9.30 & $3.10 \mathrm{E}-03$ & 1,310 & $\mathrm{BDL}$ & 4.07 \\
\hline $9 \mathrm{R}-1$ & 176.50 & 2200 & 8.00 & $3.63 \mathrm{E}-03$ & 1,320 & $\mathrm{BDL}$ & 4.80 \\
\hline $10 R-1$ & 186.25 & 3720 & 13.00 & $3.49 \mathrm{E}-03$ & 2,010 & $\mathrm{BDL}$ & 7.04 \\
\hline $11 \mathrm{R}-2$ & 197.15 & 6470 & 20.40 & $3.16 \mathrm{E}-03$ & 2,570 & $\mathrm{BDL}$ & 8.11 \\
\hline $12 R-3$ & 207.75 & 9370 & 32.10 & $3.43 \mathrm{E}-03$ & 2,450 & $\mathrm{BDL}$ & 8.40 \\
\hline $13 R-5$ & 220.85 & 17,000 & 46.40 & $2.71 \mathrm{E}-03$ & 3,310 & $\mathrm{BDL}$ & 8.96 \\
\hline $14 \mathrm{R}-3$ & 227.45 & 4470 & 16.20 & $3.62 \mathrm{E}-03$ & 2,140 & 0.21 & 7.74 \\
\hline $15 R-1$ & 233.58 & 4510 & 12.50 & $2.78 \mathrm{E}-03$ & 1,870 & 0.21 & 5.20 \\
\hline $16 R-3$ & 246.65 & 7310 & 20.30 & $2.78 \mathrm{E}-03$ & 5,280 & $\mathrm{BDL}$ & 14.67 \\
\hline $17 R-2$ & 254.75 & 125 & BDL & 0.0 & 430 & 0.15 & BDL \\
\hline $18 \mathrm{R}-3$ & 265.96 & 11,900 & 32.20 & $2.71 \mathrm{E}-03$ & 6,660 & BDL & 18.04 \\
\hline
\end{tabular}

Notes: $\mathrm{ND}=$ not determined. $\mathrm{BDL}=$ below detection limit. 
Table T7. Carbon, Holes U1317A and U1317D.

\begin{tabular}{|c|c|c|c|c|}
\hline \multirow{2}{*}{$\begin{array}{l}\text { Core, section, } \\
\text { interval (cm) }\end{array}$} & \multirow{2}{*}{$\begin{array}{l}\text { Depth } \\
\text { (mbsf) }\end{array}$} & \multirow{2}{*}{$\begin{array}{l}\text { Mass } \\
(\mathrm{mg})\end{array}$} & \multicolumn{2}{|c|}{ Carbon (wt\%) } \\
\hline & & & Inorganic & $\mathrm{CaCO}_{3}$ \\
\hline \multicolumn{5}{|l|}{ 307-U1317A- } \\
\hline $1 \mathrm{H}-1,100-101$ & 1.00 & 10.17 & 4.11 & 34.28 \\
\hline $1 \mathrm{H}-3,98-99$ & 3.98 & 10.97 & 6.31 & 52.56 \\
\hline $2 \mathrm{H}-1,47-48$ & 6.97 & 18.76 & 5.93 & 49.42 \\
\hline $2 \mathrm{H}-2,112-113$ & 9.12 & 11.20 & 7.86 & 65.50 \\
\hline $2 \mathrm{H}-4,28-29$ & 11.78 & 17.14 & 6.46 & 53.81 \\
\hline $2 \mathrm{H}-6,26-27$ & 14.76 & 12.74 & 6.88 & 57.35 \\
\hline $3 \mathrm{H}-2,25-26$ & 17.75 & 14.45 & 5.60 & 46.62 \\
\hline $3 \mathrm{H}-4,82-83$ & 21.82 & 17.52 & 1.94 & 16.14 \\
\hline $3 \mathrm{H}-5,24-25$ & 22.74 & 15.85 & 5.57 & 46.38 \\
\hline $4 \mathrm{H}-2,25-26$ & 27.25 & 11.48 & 7.13 & 59.37 \\
\hline $4 \mathrm{H}-5,25-26$ & 32.25 & 9.96 & 7.86 & 65.50 \\
\hline $5 \mathrm{H}-2,25-26$ & 36.75 & 10.48 & 7.63 & 63.52 \\
\hline $5 \mathrm{H}-5,25-26$ & 41.75 & 11.65 & 6.50 & 54.16 \\
\hline $6 \mathrm{H}-2,24-24$ & 46.24 & 12.80 & 8.04 & 67.01 \\
\hline $6 \mathrm{H}-5,28-29$ & 51.18 & 10.62 & 2.91 & 24.21 \\
\hline $7 \mathrm{H}-2,25-26$ & 55.75 & 16.88 & 8.27 & 68.89 \\
\hline $7 \mathrm{H}-5,25-26$ & 60.75 & 11.86 & 8.82 & 73.45 \\
\hline $7 \mathrm{H}-7,26-27$ & 63.26 & 13.62 & 6.24 & 51.99 \\
\hline $8 \mathrm{H}-2,26-27$ & 65.26 & 16.41 & 5.73 & 47.77 \\
\hline $8 \mathrm{H}-4,26-27$ & 68.76 & 14.27 & 8.25 & 68.72 \\
\hline $8 \mathrm{H}-5,26-27$ & 70.26 & 10.19 & 4.37 & 36.39 \\
\hline $9 \mathrm{H}-1,27-28$ & 73.27 & 13.40 & 8.20 & 68.29 \\
\hline $9 \mathrm{H}-4,26-27$ & 78.26 & 11.88 & 7.02 & 58.48 \\
\hline $9 \mathrm{H}-6,18-19$ & 81.18 & 10.16 & 2.98 & 24.82 \\
\hline $10 \mathrm{H}-2,25-26$ & 84.25 & 11.85 & 7.11 & 59.24 \\
\hline $10 \mathrm{H}-5,25-26$ & 89.25 & 11.22 & 4.17 & 34.76 \\
\hline $11 \mathrm{H}-1,61-62$ & 92.61 & 13.38 & 2.49 & 20.78 \\
\hline $11 \mathrm{H}-2,30-31$ & 93.80 & 11.51 & 5.50 & 45.83 \\
\hline $11 \mathrm{H}-4,30-31$ & 97.30 & 10.30 & 6.85 & 57.03 \\
\hline $11 \mathrm{H}-5,39-40$ & 98.89 & 11.22 & 8.16 & 68.00 \\
\hline $12 \mathrm{H}-2,25-26$ & 103.25 & 10.21 & 8.50 & 70.83 \\
\hline $12 \mathrm{H}-5,27-28$ & 108.27 & 12.78 & 7.91 & 65.86 \\
\hline $14 \mathrm{H}-0,11-12$ & 122.28 & 9.18 & 5.22 & 43.48 \\
\hline $14 \mathrm{H}-2,28-29$ & 127.26 & 14.10 & 3.47 & 28.88 \\
\hline $14 \mathrm{H}-5,26-27$ & 128.83 & 11.53 & 7.38 & 61.46 \\
\hline $14 \mathrm{H}-6,33-34$ & 129.98 & 14.53 & 4.27 & 35.58 \\
\hline $14 \mathrm{H}-6,148-149$ & 130.54 & 12.03 & 5.99 & 49.91 \\
\hline
\end{tabular}

\begin{tabular}{|c|c|c|c|c|}
\hline \multirow{2}{*}{$\begin{array}{l}\text { Core, section, } \\
\text { interval (cm) }\end{array}$} & \multirow{2}{*}{$\begin{array}{l}\text { Depth } \\
\text { (mbsf) }\end{array}$} & \multirow{2}{*}{$\begin{array}{l}\text { Mass } \\
(\mathrm{mg})\end{array}$} & \multicolumn{2}{|c|}{ Carbon (wt\%) } \\
\hline & & & Inorganic & $\mathrm{CaCO}_{3}$ \\
\hline $15 \mathrm{H}-1,32-33$ & 130.32 & 13.81 & 5.50 & 45.82 \\
\hline $17 X-2,41-42$ & 133.21 & 15.31 & 4.01 & 33.39 \\
\hline $17 X-2,41-42$ & 133.21 & 12.86 & 3.99 & 33.25 \\
\hline $18 X-1,19-20$ & 136.49 & 14.99 & 3.83 & 31.88 \\
\hline \multicolumn{5}{|l|}{ 307-U1317D- } \\
\hline $3 R-1,26-27$ & 126.86 & 11.06 & 6.37 & 53.03 \\
\hline $4 \mathrm{R}-1,26-27$ & 136.46 & 10.50 & 2.08 & 17.36 \\
\hline $5 R-1,19-20$ & 145.99 & 11.81 & 7.11 & 59.20 \\
\hline $5 R-1,52-53$ & 146.32 & 10.39 & 5.13 & 42.70 \\
\hline $6 \mathrm{R}-3,26-27$ & 154.16 & 10.77 & 3.69 & 30.76 \\
\hline 7R-1, 26-27 & 155.66 & 10.06 & 3.81 & 31.76 \\
\hline $7 R-4,31-32$ & 160.71 & 11.24 & 4.50 & 37.46 \\
\hline $8 R-1,22-23$ & 165.32 & 11.11 & 4.47 & 37.25 \\
\hline $8 \mathrm{R}-5,30-31$ & 171.87 & 11.54 & 3.89 & 32.44 \\
\hline $9 \mathrm{R}-2,30-31$ & 177.00 & 10.99 & 5.06 & 42.13 \\
\hline 9R-4, 107-108 & 180.77 & 11.14 & 6.18 & 51.51 \\
\hline $10 \mathrm{R}-1,25-26$ & 184.55 & 10.80 & 3.27 & 27.23 \\
\hline 10R-3, 34-35 & 188.09 & 10.97 & 4.62 & 38.53 \\
\hline $11 \mathrm{R}-1,25-26$ & 194.15 & 12.71 & 3.33 & 27.74 \\
\hline $11 \mathrm{R}-3,26-27$ & 197.66 & 15.98 & 3.07 & 25.56 \\
\hline $12 \mathrm{R}-1,99-100$ & 204.49 & 16.07 & 5.24 & 43.65 \\
\hline $12 \mathrm{R}-3,22-23$ & 206.22 & 15.77 & 5.86 & 48.82 \\
\hline $13 R-2,24-25$ & 214.84 & 13.22 & 4.33 & 36.08 \\
\hline 13R-5, 36-37 & 219.46 & 11.78 & 2.95 & 24.61 \\
\hline $14 \mathrm{R}-2,20-21$ & 224.40 & 10.74 & 3.02 & 25.16 \\
\hline 14R-5, 20-21 & 229.40 & 13.31 & 3.33 & 27.72 \\
\hline 15R-1, 20-21 & 232.50 & 10.80 & 4.21 & 35.04 \\
\hline $16 \mathrm{R}-2,123-125$ & 244.63 & 10.95 & 6.85 & 57.06 \\
\hline 16R-5, 79-81 & 249.19 & 10.91 & 8.95 & 74.56 \\
\hline $17 \mathrm{R}-2,23-25$ & 253.23 & 10.81 & 5.51 & 45.87 \\
\hline $17 R-4,24-26$ & 256.74 & 11.53 & 5.74 & 47.85 \\
\hline 18R-2, 111-113 & 263.82 & 10.26 & 5.79 & 48.23 \\
\hline $18 R-4,28-30$ & 266.49 & 11.49 & 4.36 & 36.29 \\
\hline \multirow[t]{3}{*}{$18 \mathrm{R}-4,68-70$} & 266.89 & 10.50 & 4.22 & 35.13 \\
\hline & & & Average: & 45.45 \\
\hline & & \multicolumn{2}{|c|}{ Standard deviation: } & 15.18 \\
\hline
\end{tabular}


Table T8. Contamination test results from the use of perfluorocarbon tracer and fluorescent microspheres, Holes U1317A and U1317D.

\begin{tabular}{|c|c|c|c|c|c|c|}
\hline Core, section & Depth (mbsf) & PFC-out & PFC-in & Catwalk & Drill fluid & $\begin{array}{l}\text { Fluorescent } \\
\text { microspheres }\end{array}$ \\
\hline \multicolumn{7}{|l|}{ 307-1317A- } \\
\hline $1 \mathrm{H}-3$ & $4.85-4.90$ & - & $\mathrm{BDL}$ & - & - & 0 \\
\hline $2 \mathrm{H}-3$ & $11.35-11.40$ & - & $\mathrm{BDL}$ & - & - & 62 \\
\hline $3 \mathrm{H}-3$ & $20.85-20.90$ & - & $\mathrm{BDL}$ & - & - & 993 \\
\hline $4 \mathrm{H}-4$ & $31.85-31.90$ & - & BDL & - & - & 0 \\
\hline $5 \mathrm{H}-3$ & $39.85-39.90$ & - & BDL & - & - & 794 \\
\hline $6 \mathrm{H}-3$ & $49.35-49.40$ & - & BDL & - & - & 103 \\
\hline $7 \mathrm{H}-3$ & $58.85-58.90$ & - & BDL & - & - & 0 \\
\hline $8 \mathrm{H}-3$ & $68.35-68.40$ & - & BDL & - & - & 0 \\
\hline $9 \mathrm{H}-3$ & $77.85-77.90$ & - & BDL & - & - & 0 \\
\hline $10 \mathrm{H}-3$ & $87.35-87.40$ & - & BDL & - & - & 0 \\
\hline $11 \mathrm{H}-3$ & $96.85-96.90$ & - & BDL & - & - & 21 \\
\hline $12 \mathrm{H}-3$ & $106.35-106.40$ & - & $\mathrm{BDL}$ & - & - & 0 \\
\hline $13 \mathrm{H}-3$ & $115.85-115.90$ & - & BDL & - & - & 0 \\
\hline $14 \mathrm{H}-3$ & $125.35-125.40$ & - & BDL & - & - & 62 \\
\hline $17 X-1$ & $132.65-132.70$ & - & $\mathrm{BDL}$ & - & - & 0 \\
\hline $18 X-1$ & $136.80-136.85$ & - & Trace & - & - & 0 \\
\hline \multicolumn{7}{|l|}{ 307-1317D- } \\
\hline $3 R-2$ & $129.90-129.95$ & BDL & BDL & - & Positive & 0 \\
\hline $4 \mathrm{R}-1$ & $136.20-136.25$ & - & - & - & - & 0 \\
\hline $5 \mathrm{R}-1$ & $147.73-147.78$ & Positive & BDL & - & - & 0 \\
\hline $6 \mathrm{R}-1$ & $152.20-152.25$ & Positive & BDL & BDL & Positive & 0 \\
\hline $7 \mathrm{R}-2$ & $158.70-158.75$ & Positive & BDL & - & - & 0 \\
\hline $8 \mathrm{R}-2$ & 168.37-168.42 & Positive & BDL & - & - & 0 \\
\hline 9R-1 & $176.50-176.55$ & Positive & $\mathrm{BDL}$ & - & - & 0 \\
\hline 10R-1 & $186.25-186.30$ & Positive & Trace & - & - & 0 \\
\hline $11 \mathrm{R}-2$ & $197.15-197.20$ & Positive & $\mathrm{BDL}$ & - & Positive & 0 \\
\hline $12 \mathrm{R}-3$ & $207.75-207.80$ & Positive & BDL & - & - & 0 \\
\hline $13 R-5$ & $220.85-220.90$ & Positive & BDL & - & - & 0 \\
\hline $14 \mathrm{R}-3$ & $227.45-227.50$ & Positive & BDL & - & - & 0 \\
\hline $15 R-3$ & $233.58-233.63$ & Positive & BDL & - & - & 0 \\
\hline $16 \mathrm{R}-3$ & $246.65-246.70$ & Positive & BDL & - & - & 0 \\
\hline $17 \mathrm{R}-2$ & $254.75-254.80$ & Positive & BDL & BDL & - & 0 \\
\hline $18 \mathrm{R}-2$ & $265.96-266.01$ & Positive & $\mathrm{BDL}$ & $\mathrm{BDL}$ & - & 0 \\
\hline
\end{tabular}

Notes: $\mathrm{PFC}$-out = sample from the core periphery (interface between liner and core), PFC-in = sample from the inner core section between center and periphery. $-=$ no sample taken, $\mathrm{BDL}=$ below detection limit. 
Table T9. Logging operations, Hole U1317D.

\begin{tabular}{ccl}
\hline $\begin{array}{c}\text { Date } \\
\text { (May 2005) }\end{array}$ & $\begin{array}{c}\text { Local } \\
\text { time }(\mathrm{h})\end{array}$ & \multicolumn{1}{c}{ Comments } \\
\hline 6 & 1200 & Hole preparation complete, rig up triple combo (HNGS-APS-HLDS-DIT-EMS-TAP) \\
6 & 1415 & $\begin{array}{l}\text { Run into hole with triple combo } \\
\text { Uplog with triple combo at } 900 \mathrm{ft} / \mathrm{h} \text { from total depth }\end{array}$ \\
6 & 1515 & Pull tools out of hole and rig down \\
6 & 1600 & Rig up WST \\
6 & 1715 & Run into hole with WST \\
6 & 1740 & Uplog with WST (13 stations) 5 min/station \\
6 & 2830 & Pull WST out of hole and rig down \\
6 & 2130 & Rig up FMS-sonic (SGT-DSI-GPIT-FMS) \\
6 & 2215 & Run into hole with FMS-sonic \\
6 & 2315 & First pass with FMS at 900 ft/h from obstruction 251 mbsf \\
6 & 2345 & Going down for a main pass to seafloor \\
7 & 0000 & Uplog with FMS at 900 ft/h from obstruction \\
7 & 0100 & Pull tools out of hole and rig down \\
7 & 0200 & Clear rig floor of logging tools, sheaves, and wireline \\
7 & 0230 & End of logging operation \\
\hline
\end{tabular}

Notes: Drillers total depth $=1076 \mathrm{mbrf}$, water depth $=806 \mathrm{~m}$, end of pipe $=77 \mathrm{mbsf}$, total cored depth $=270 \mathrm{mbsf}$, total logged depth $=251$ mbsf. Triple combo = triple combination, HNGS = Hostile Environment Natural Gamma Ray Sonde, APS = Accelerator Porosity Sonde, HLDS = Hostile Environment Litho-Density Sonde, DIT = Dual Induction Tool, EMS = Environmental Measurement Sonde, TAP = Temperature/Acceleration/Pressure tool, WST = Well Seismic Tool, SGT = Scintillation Gamma Ray Tool, DSI = Dipole Sonic Imager, GPIT = General Purpose Inclinometry Tool, FMS = Formation MicroScanner.

Table T10. Check shot survey, Hole U1317D.

\begin{tabular}{cccccc}
\hline $\begin{array}{c}\text { Stack } \\
\text { number }\end{array}$ & $\begin{array}{c}\text { Measured } \\
\text { depth }(\mathrm{m})\end{array}$ & $\begin{array}{c}\text { Depth } \\
(\mathrm{mbsf})\end{array}$ & $\begin{array}{c}\text { Measured } \\
\text { OWT }(\mathrm{ms})\end{array}$ & $\begin{array}{c}\text { Corrected } \\
\text { OWT }(\mathrm{ms})\end{array}$ & $\begin{array}{c}\text { Interval } \\
\text { velocity }(\mathrm{m} / \mathrm{s})\end{array}$ \\
\hline 13 & 905 & 94 & 583.43 & 583.86 & 1767.86 \\
12 & 915 & 104 & 589.07 & 589.52 & 1982.16 \\
11 & 925 & 114 & 594.11 & 594.56 & 1723.99 \\
10 & 935 & 124 & 599.90 & 600.36 & 1938.86 \\
9 & 945 & 134 & 605.04 & 605.52 & 1770.69 \\
8 & 955 & 144 & 610.68 & 611.17 & 2032.27 \\
7 & 965 & 154 & 615.59 & 616.09 & 1901.70 \\
6 & 980 & 169 & 623.52 & 624.03 & 2005.52 \\
5 & 995 & 184 & 630.98 & 631.51 & 1978.63 \\
4 & 1010 & 199 & 638.49 & 639.04 & 1669.09 \\
3 & 1025 & 214 & 646.15 & 646.71 & 2201.70 \\
2 & 1040 & 229 & 652.90 & 653.47 & 2161.09 \\
1 & 1056 & 245 & 660.29 & 660.88 & - \\
\hline
\end{tabular}

Note: OWT = one-way traveltime, $-=$ no data. 